McNeill, L.C., Shillington, D.J., Carter, G.D.O., and the Expedition 381 Participants

Proceedings of the International Ocean Discovery Program Volume 381

publications.iodp.org

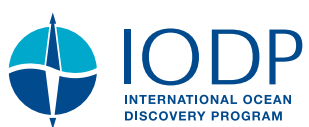

https://doi.org/10.14379/iodp.proc.381.104.2019

Check for updates

Contents

\title{
Site $\mathrm{M0078}^{1}$
}

L.C. McNeill, D.J. Shillington, G.D.O. Carter, J.D. Everest, E. Le Ber, R.E.Ll. Collier, A. Cvetkoska, G. De Gelder, P. Diz, M.-L. Doan, M. Ford, R.L. Gawthorpe, M. Geraga, J. Gillespie, R. Hemelsdaël, E. Herrero-Bervera, M. Ismaiel, L. Janikian, K. Kouli, S. Li, M.L. Machlus, M. Maffione, C. Mahoney, G. Michas, C. Miller, C.W. Nixon, S.A. Oflaz, A.P. Omale, K. Panagiotopoulos, S. Pechlivanidou, M.P. Phillips, S. Sauer, J. Seguin, S. Sergiou, and N.V. Zakharova ${ }^{2}$

Keywords: International Ocean Discovery Program, IODP, D/V Fugro Synergy, mission-specific platform, Expedition 381, Site M0078, Corinth rift, Gulf of Corinth, Alkyonides Gulf, Eastern Mediterranean Sea, Aegean Sea, continental rifting, extension, active rift, normal fault, earthquake, horst, fault growth, rift development, synrift stratigraphy, drainage evolution, surface processes, basin paleoenvironment, glacio-eustatic cycles, sea level, semi-isolated basin, marine basin, lacustrine, sediment flux, Quaternary, Pliocene, Miocene, carbon cycling, nutrient preservation, marine isotope stage

\section{Operations}

During International Ocean Discovery Program (IODP) Expedition 381, cores were recovered from two holes at Site M0078 (Figures F1, F2). In total, 20.27 days were spent on station, with an average core recovery of $88 \%$ for the site (Table T1). Hole M0078A was drilled to 610.43 meters below seafloor (mbsf), and Hole M0078B was drilled to 55.85 mbsf.

In Hole M0078A, the Fugro Wison Extended Piston (WEP) system was used to core the upper $75 \mathrm{~m}$, and the Fugro Corer in push mode was used for the next $124 \mathrm{~m}$, followed by the same corer in percussive mode for $25 \mathrm{~m}$. The Fugro Extended Marine Core Barrel (FXMCB) (rotary) was used to core the final $386 \mathrm{~m}$ of the borehole. In Hole M0078B, the Fugro Corer in push mode was used throughout to the base of the hole at 55.85 mbsf.

\section{Transit to Hole M0078A}

The D/V Fugro Synergy prepared to sail on the evening of 22 October 2017, and the vessel departed the Port of Corinth at $1955 \mathrm{~h}$ (local time) for the first coring site. At 2130 h, the Fugro Synergy arrived at Site M0078, and a dynamic positioning model was established. A reference beacon was deployed, and a sound velocity profile was conducted. Water depths for Holes M0078A and M0078B are 859.5 and $864 \mathrm{~m}$, respectively.

\section{Hole M0078A}

\section{Coring operations}

At $0145 \mathrm{~h}$ (local time) on 23 October 2017, the seabed frame (SBF) was deployed, and the drilling crew began running pipe. However, running pipe took longer than anticipated because rust at the joints resulted in the need for a thorough cleaning prior to deployment.

During the evening of 23 October, the first cores were recovered with the first core on deck at $2135 \mathrm{~h}$. The SEADEVIL (an addition to the standard seabed template) was used to accurately spud in and collect a seabed/water interface sample. The WEP system was lowered to approximately $10 \mathrm{~cm}$ above the seabed and energized. The first core was $2.65 \mathrm{~m}$ long. The next attempt at coring was unsuccessful, and the decision was made to wash through this interval. Following the wash through, coring continued throughout 23 and 24 October, generally with high recovery rates. On 25 October, recovery gradually worsened, prompting a switch to the Fugro Corer in push mode with flapper and finger catchers to optimize recovery. Initially, $3 \mathrm{~m}$ runs were conducted, but runs were extended to $4.7 \mathrm{~m}$ on the evening of 25 October.

At $2130 \mathrm{~h}$ on 25 October, a communication issue arose with the SEADEVIL, leading to its recovery on deck at $0300 \mathrm{~h}$ on 26 October for assessment. Further investigation identified a printed circuit

\footnotetext{
${ }^{1}$ McNeill, L.C., Shillington, D.J., Carter, G.D.O., Everest, J.D., Le Ber, E., Collier, R.E.LI., Cvetkoska, A., De Gelder, G., Diz, P., Doan, M.-L., Ford, M., Gawthorpe, R.L., Geraga, M., Gillespie, J., Hemelsdaël, R., Herrero-Bervera, E., Ismaiel, M., Janikian, L., Kouli, K., Li, S., Machlus, M.L., Maffione, M., Mahoney, C., Michas, G., Miller, C., Nixon, C.W., Oflaz, S.A., Omale, A.P., Panagiotopoulos, K., Pechlivanidou, S., Phillips, M.P., Sauer, S., Seguin, J., Sergiou, S., Zakharova, N.V., 2019. Site M0078. In McNeill, L.C., Shillington, D.J., Carter, G.D.O., and the Expedition 381 Participants, Corinth Active Rift Development. Proceedings of the International Ocean Discovery Program, 381: College Station, TX (International Ocean Discovery Program). https://doi.org/10.14379/iodp.proc.381.104.2019

2 Expedition 381 Participants' affiliations.

MS 381-104: Published 28 February 2019

This work is distributed under the Creative Commons Attribution 4.0 International (CC BY 4.0) license. (c)) B
} 
Figure F1. Corinth rift with primary rift-related faults (both active and currently inactive), multibeam bathymetry of the gulf, and Expedition 381 drill sites. Offshore fault traces are derived from Nixon et al. (2016), building on Bell et al. (2009) and Taylor et al. (2011). Onshore fault traces are derived from Ford et al. $(2007,2013)$ and Skourtsos and Kranis (2009). Bathymetry data provided by the Hellenic Centre for Marine Research and collected during R/V Aegaeo cruises (Sakellariou et al., 2007). Inset: tectonic setting of Corinth rift in Aegean region, Eastern Mediterranean Sea.

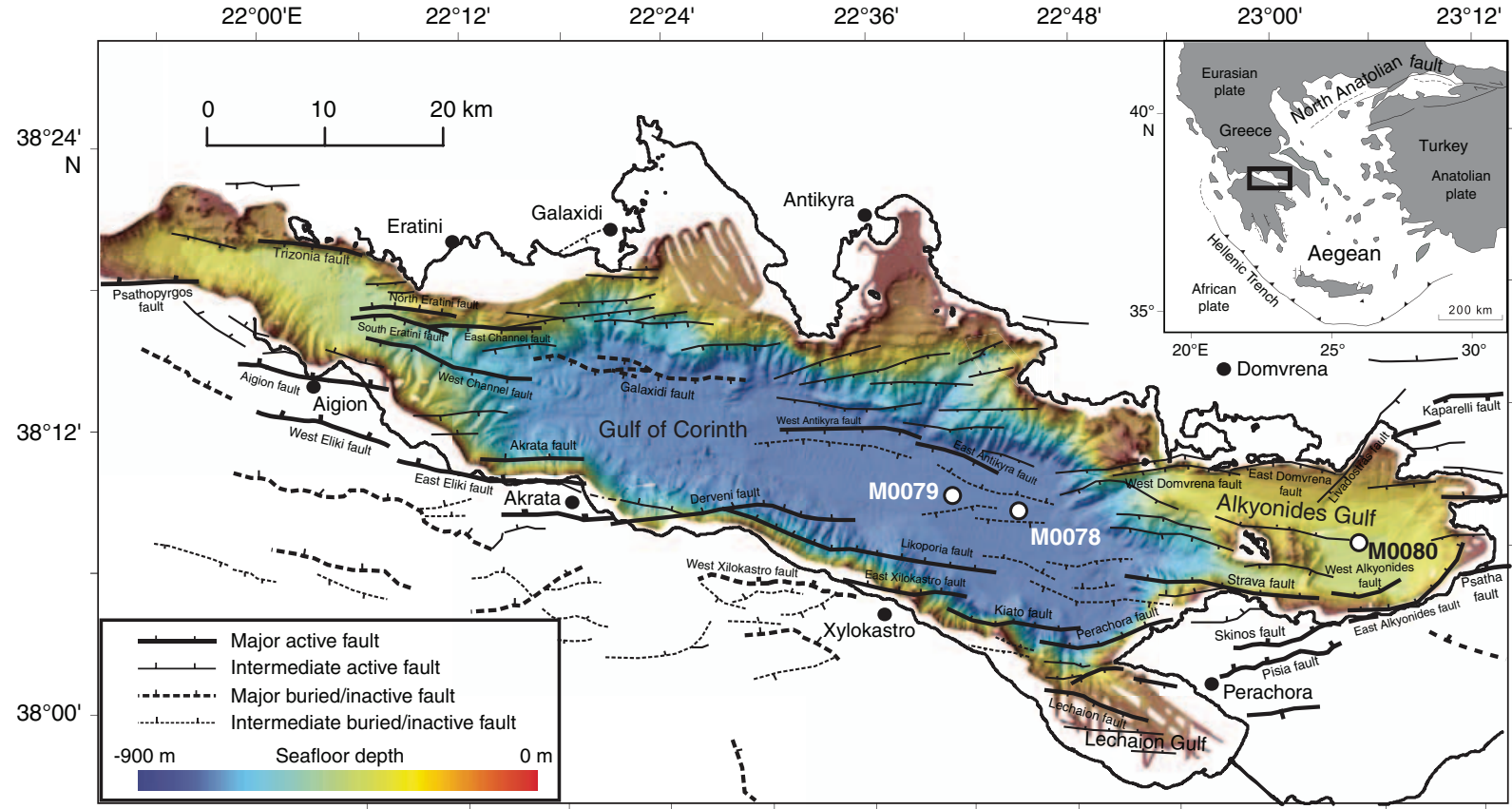

Figure F2. Site M0078 shown with R/V Maurice Ewing Line 42 (Taylor et al., 2011) and interpretations from Nixon et al. (2016) (colored dotted lines and text). $\mathrm{CDP}=$ common depth point, $\mathrm{TWT}=$ two-way traveltime. Inset: seismic line and drill site locations.

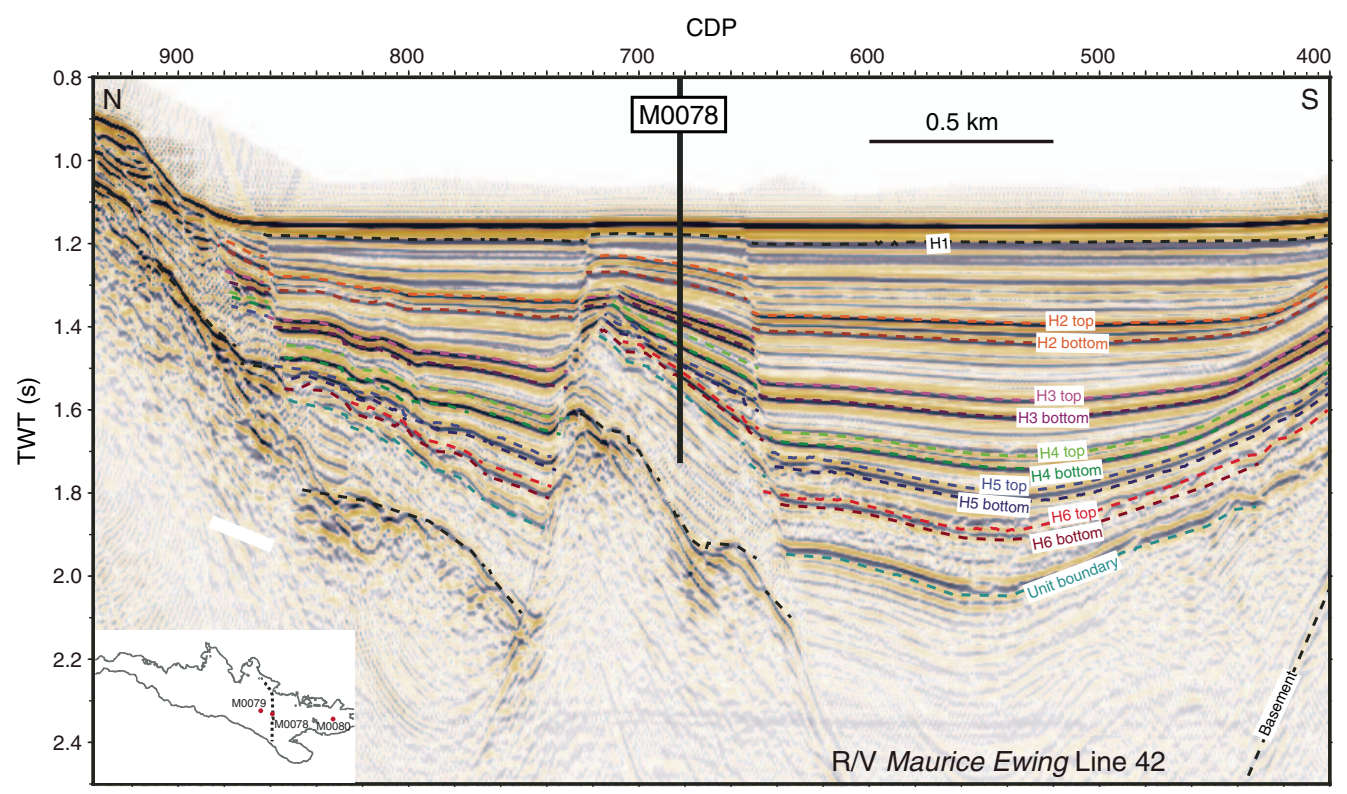

board fault, and the board was replaced. At $1415 \mathrm{~h}$, the SEADEVIL was redeployed to the seabed, and the drill pipe was extended to the base of the hole so that coring could recommence. The first core was recovered on deck at $1610 \mathrm{~h}$. Coring paused briefly on 26 October to undertake an in situ temperature cone penetration test (CPT) measurement at $100 \mathrm{mbsf}$; temperature CPT measurements were also taken close to 200 and 300 mbsf in Hole M0078A. Coring with the Fugro Corer continued for the remainder of 26 October and through 28 October. At 0840 h, core Run 60 made no advance, and the run was repeated at the same interval (core Run 61). A $2 \mathrm{~m}$ advance was achieved, but no core was returned. Next, a $4.57 \mathrm{~m}$ run (core Run 62) was conducted with good recovery.

Recovery became more variable on 28 and 29 October, and some runs returned no core. As a result, in the early hours of 29 October it was decided to change the Fugro Corer from push mode to percussive mode. Despite this change, recovery continued to be highly variable, and at $2130 \mathrm{~h}$, the operational decision was made to change from the Fugro Corer to the FXMCB system. 
Table T1. Drilling operations, Site M0078. EET = Eastern European Time. Core type: $\mathrm{H}=$ Fugro Wison Extended Piston (WEP) system (equivalent to IODP's advanced piston corer $[A P C]$ ), $P=$ Fugro Corer $(F C)$ in push mode (near equivalent to $A P C), V=F C$ in percussive mode (near equivalent to $A P C$ ), $R=$ Fugro Extended Marine Core Barrel (FXMCB; equivalent to IODP's rotary core barrel [RCB]). Recovery sometimes exceeds $100 \%$ because of core expansion. (Continued on next 2 pages.) Download table in CSV format.

\begin{tabular}{|c|c|c|c|c|c|c|c|c|}
\hline Core & $\begin{array}{l}\text { Coring } \\
\text { method }\end{array}$ & Date & $\begin{array}{l}\text { Time EET } \\
\text { (h) }\end{array}$ & $\begin{array}{c}\text { Top } \\
\text { depth } \\
\text { (mbsf) }\end{array}$ & $\begin{array}{l}\text { Bottom } \\
\text { depth } \\
\text { (mbsf) }\end{array}$ & $\begin{array}{l}\text { Core } \\
\text { recovered } \\
(\mathrm{m})\end{array}$ & $\begin{array}{l}\text { Recovery } \\
\text { (\%) }\end{array}$ & Mud type \\
\hline \multicolumn{9}{|c|}{ 381-M0078A- } \\
\hline $1 \mathrm{H}$ & WEP & 23 Oct 2017 & 2135 & 0.00 & 2.65 & 2.65 & 100 & Seawater \\
\hline $2 \mathrm{H}$ & WEP & 23 Oct 2017 & 2305 & 2.65 & 5.65 & 0.00 & 0 & Seawater \\
\hline $3 \mathrm{H}$ & WEP & 24 Oct 2017 & 0230 & 5.65 & 7.00 & 1.37 & 101.5 & Seawater \\
\hline $4 \mathrm{H}$ & WEP & 24 Oct 2017 & 0410 & 7.00 & 9.35 & 2.38 & 101.3 & Seawater \\
\hline $5 \mathrm{H}$ & WEP & 24 Oct 2017 & 0605 & 9.35 & 11.95 & 2.62 & 100.8 & Seawater \\
\hline $6 \mathrm{H}$ & WEP & 24 Oct 2017 & 0740 & 11.95 & 14.32 & 2.31 & 97.5 & Seawater \\
\hline $7 \mathrm{H}$ & WEP & 24 Oct 2017 & 0915 & 14.32 & 16.78 & 2.30 & 93.5 & Seawater \\
\hline $8 \mathrm{H}$ & WEP & 24 Oct 2017 & 1045 & 16.78 & 19.21 & 2.46 & 101.2 & Seawater \\
\hline $9 \mathrm{H}$ & WEP & 24 Oct 2017 & 1215 & 19.21 & 21.86 & 2.64 & 99.6 & Seawater \\
\hline $10 \mathrm{H}$ & WEP & 24 Oct 2017 & 1345 & 21.86 & 24.54 & 2.70 & 100.8 & Seawater \\
\hline $11 \mathrm{H}$ & WEP & 24 Oct 2017 & 1455 & 24.54 & 26.94 & 2.44 & 101.7 & Seawater \\
\hline $12 \mathrm{H}$ & WEP & 24 Oct 2017 & 1625 & 26.94 & 29.94 & 2.33 & 77.7 & Seawater \\
\hline $13 \mathrm{H}$ & WEP & 24 Oct 2017 & 1755 & 29.94 & 31.79 & 1.37 & 74.1 & Seawater \\
\hline $14 \mathrm{H}$ & WEP & 24 Oct 2017 & 1915 & 31.79 & 34.79 & 2.77 & 92.3 & Seawater \\
\hline $15 \mathrm{H}$ & WEP & 24 Oct 2017 & 2025 & 34.79 & 37.79 & 2.50 & 83.3 & Seawater \\
\hline $16 \mathrm{H}$ & WEP & 24 Oct 2017 & 2135 & 37.79 & 40.79 & 1.91 & 63.7 & Seawater \\
\hline $17 \mathrm{H}$ & WEP & 24 Oct 2017 & 2320 & 40.79 & 43.79 & 1.76 & 58.7 & Seawater \\
\hline $18 \mathrm{H}$ & WEP & 25 Oct 2017 & 0050 & 43.79 & 46.79 & 2.58 & 86 & Seawater \\
\hline $19 \mathrm{H}$ & WEP & 25 Oct 2017 & 0230 & 46.79 & 49.79 & 2.70 & 90 & Seawater \\
\hline $20 \mathrm{H}$ & WEP & 25 Oct 2017 & 0345 & 49.79 & 52.79 & 2.53 & 84.3 & Seawater \\
\hline $21 \mathrm{H}$ & WEP & 25 Oct 2017 & 0500 & 52.79 & 55.79 & 2.55 & 85 & Seawater \\
\hline $22 \mathrm{H}$ & WEP & 25 Oct 2017 & 0645 & 55.79 & 58.79 & 1.90 & 63.3 & Seawater \\
\hline $23 \mathrm{H}$ & WEP & 25 Oct 2017 & 0800 & 58.79 & 61.79 & 2.12 & 70.7 & Seawater \\
\hline $24 \mathrm{H}$ & WEP & 25 Oct 2017 & 0915 & 61.79 & 64.79 & 2.61 & 87 & Seawater \\
\hline $25 \mathrm{H}$ & WEP & 25 Oct 2017 & 1130 & 64.79 & 67.79 & 1.13 & 37.7 & Seawater \\
\hline $26 \mathrm{H}$ & WEP & 25 Oct 2017 & 1255 & 67.79 & 70.79 & 2.34 & 78 & Seawater \\
\hline $27 \mathrm{H}$ & WEP & 25 Oct 2017 & 1420 & 70.79 & 72.19 & 1.00 & 71.4 & Seawater \\
\hline $28 \mathrm{H}$ & WEP & 25 Oct 2017 & 1600 & 72.19 & 75.19 & 1.33 & 44.3 & Seawater \\
\hline $29 P$ & $\mathrm{FC}$ & 25 Oct 2017 & 1745 & 75.19 & 78.19 & 3.04 & 101.3 & Seawater \\
\hline $30 P$ & $\mathrm{FC}$ & 25 Oct 2017 & 1920 & 78.19 & 81.59 & 3.17 & 93.2 & Seawater \\
\hline $31 \mathrm{P}$ & $\mathrm{FC}$ & 25 Oct 2017 & 2035 & 81.59 & 85.59 & 4.10 & 102.5 & Seawater \\
\hline $32 \mathrm{P}$ & $\mathrm{FC}$ & 25 Oct 2017 & 2200 & 85.59 & 90.04 & 4.62 & 103.8 & Seawater \\
\hline $33 \mathrm{P}$ & $\mathrm{FC}$ & 26 Oct 2017 & 1600 & 90.04 & 94.14 & 2.24 & 54.6 & Seawater \\
\hline $34 \mathrm{P}$ & $\mathrm{FC}$ & 26 Oct 2017 & 1715 & 94.14 & 97.94 & 3.75 & 98.7 & Seawater \\
\hline $35 \mathrm{P}$ & $\mathrm{FC}$ & 26 Oct 2017 & 1845 & 97.94 & 102.64 & 4.61 & 98.1 & Seawater \\
\hline $36 \mathrm{P}$ & $\mathrm{FC}$ & 26 Oct 2017 & 2115 & 102.64 & 106.04 & 3.31 & 97.4 & Seawater \\
\hline $37 \mathrm{P}$ & $\mathrm{FC}$ & 26 Oct 2017 & 2224 & 106.04 & 109.04 & 2.72 & 90.7 & Seawater \\
\hline $38 \mathrm{P}$ & $\mathrm{FC}$ & 27 Oct 2017 & 0030 & 109.04 & 113.74 & 4.75 & 101.1 & Seawater \\
\hline $39 P$ & $\mathrm{FC}$ & 27 Oct 2017 & 0240 & 113.74 & 115.24 & 1.49 & 99.3 & Seawater \\
\hline $40 \mathrm{P}$ & $\mathrm{FC}$ & 27 Oct 2017 & 0400 & 115.24 & 118.34 & 3.08 & 99.4 & Seawater \\
\hline $41 \mathrm{P}$ & $\mathrm{FC}$ & 27 Oct 2017 & 0520 & 118.34 & 122.84 & 4.47 & 99.3 & Seawater \\
\hline $42 \mathrm{P}$ & $\mathrm{FC}$ & 27 Oct 2017 & 0710 & 122.84 & 125.94 & 2.93 & 94.5 & Seawater \\
\hline $43 \mathrm{P}$ & $\mathrm{FC}$ & 27 Oct 2017 & 0905 & 125.94 & 130.04 & 4.20 & 100 & Seawater \\
\hline $44 \mathrm{P}$ & $\mathrm{FC}$ & 27 Oct 2017 & 1020 & 130.04 & 132.64 & 2.57 & 98.9 & Seawater \\
\hline $45 \mathrm{P}$ & $\mathrm{FC}$ & 27 Oct 2017 & 1155 & 132.64 & 134.74 & 2.05 & 97.6 & Seawater \\
\hline $46 \mathrm{P}$ & $\mathrm{FC}$ & 27 Oct 2017 & 1325 & 134.74 & 137.14 & 2.35 & 97.9 & Seawater \\
\hline $47 \mathrm{P}$ & $\mathrm{FC}$ & 27 Oct 2017 & 1445 & 137.14 & 139.14 & 1.97 & 98.5 & Seawater \\
\hline $48 \mathrm{P}$ & $\mathrm{FC}$ & 27 Oct 2017 & 1600 & 139.14 & 142.44 & 3.20 & 97 & Seawater \\
\hline $49 \mathrm{P}$ & $\mathrm{FC}$ & 27 Oct 2017 & 1725 & 142.44 & 146.94 & 4.36 & 96.9 & Seawater \\
\hline $50 \mathrm{P}$ & $\mathrm{FC}$ & 27 Oct 2017 & 1855 & 146.94 & 150.44 & 3.50 & 100 & Seawater \\
\hline $51 \mathrm{P}$ & $\mathrm{FC}$ & 27 Oct 2017 & 2000 & 150.44 & 152.94 & 2.44 & 97.6 & Seawater \\
\hline $52 \mathrm{P}$ & $\mathrm{FC}$ & 27 Oct 2017 & 2120 & 152.94 & 157.74 & 4.50 & 93.8 & Seawater \\
\hline $53 \mathrm{P}$ & $\mathrm{FC}$ & 27 Oct 2017 & 2235 & 157.74 & 162.14 & 4.23 & 96.1 & Seawater \\
\hline $54 \mathrm{P}$ & $\mathrm{FC}$ & 28 Oct 2017 & 0005 & 162.14 & 166.24 & 4.15 & 101.2 & Seawater \\
\hline $55 \mathrm{P}$ & $\mathrm{FC}$ & 28 Oct 2017 & 0140 & 166.24 & 169.24 & 3.13 & 104.3 & Seawater \\
\hline $56 \mathrm{P}$ & $\mathrm{FC}$ & 28 Oct 2017 & 0255 & 169.24 & 172.34 & 3.08 & 99.4 & Seawater \\
\hline $57 \mathrm{P}$ & $\mathrm{FC}$ & 28 Oct 2017 & 0445 & 172.34 & 173.84 & 1.44 & 96 & Seawater \\
\hline $58 \mathrm{P}$ & $\mathrm{FC}$ & 28 Oct 2017 & 0620 & 173.84 & 176.64 & 2.85 & 101.8 & Seawater \\
\hline $59 P$ & $\mathrm{FC}$ & 28 Oct 2017 & 0720 & 176.64 & 178.14 & 1.46 & 97.3 & Seawater \\
\hline $60 P$ & $\mathrm{FC}$ & 28 Oct 2017 & 0840 & 178.14 & 178.14 & 0.00 & 0 & Seawater \\
\hline $61 \mathrm{P}$ & $\mathrm{FC}$ & 28 Oct 2017 & 0940 & 178.14 & 180.14 & 0.00 & 0 & Seawater \\
\hline $62 \mathrm{P}$ & FC & 28 Oct 2017 & 1130 & 180.14 & 184.64 & 4.57 & 101.6 & Seawater \\
\hline $63 \mathrm{P}$ & FC & 28 Oct 2017 & 1300 & 184.64 & 185.14 & 0.00 & 0 & Seawater \\
\hline $64 \mathrm{P}$ & FC & 28 Oct 2017 & 1415 & 185.14 & 186.24 & 1.03 & 93.6 & Seawater \\
\hline
\end{tabular}


Table T1 (continued). (Continued on next page.)

\begin{tabular}{|c|c|c|c|c|c|c|c|c|}
\hline Core & $\begin{array}{l}\text { Coring } \\
\text { method }\end{array}$ & Date & $\begin{array}{l}\text { Time EET } \\
\text { (h) }\end{array}$ & $\begin{array}{l}\text { Top } \\
\text { depth } \\
\text { (mbsf) }\end{array}$ & $\begin{array}{l}\text { Bottom } \\
\text { depth } \\
\text { (mbsf) }\end{array}$ & $\begin{array}{l}\text { Core } \\
\text { recovered } \\
(\mathrm{m})\end{array}$ & $\begin{array}{c}\text { Recovery } \\
\text { (\%) }\end{array}$ & Mud type \\
\hline $65 \mathrm{P}$ & FC & 28 Oct 2017 & 1545 & 186.24 & 188.14 & 1.91 & 100.5 & Seawater \\
\hline $66 \mathrm{P}$ & FC & 28 Oct 2017 & 1715 & 188.14 & 190.54 & 0.65 & 27.1 & Seawater \\
\hline $67 \mathrm{P}$ & FC & 28 Oct 2017 & 1840 & 190.54 & 193.24 & 0.16 & 5.9 & Seawater \\
\hline $68 \mathrm{P}$ & FC & 28 Oct 2017 & 2015 & 193.24 & 195.04 & 1.76 & 97.8 & Seawater \\
\hline $69 \mathrm{P}$ & FC & 28 Oct 2017 & 2125 & 195.04 & 197.64 & 2.43 & 93.5 & Seawater \\
\hline $70 \mathrm{P}$ & FC & 28 Oct 2017 & 2245 & 197.64 & 199.14 & 1.50 & 100 & Seawater \\
\hline $71 \mathrm{~V}$ & FC & 29 Oct 2017 & 0010 & 199.14 & 202.34 & 3.14 & 98.1 & Seawater \\
\hline $72 \mathrm{~V}$ & FC & 29 Oct 2017 & 0310 & 202.34 & 205.54 & 3.29 & 102.8 & Bentonite \\
\hline $73 \mathrm{~V}$ & FC & 29 Oct 2017 & 0435 & 205.54 & 208.44 & 2.29 & 79 & Bentonite \\
\hline $74 \mathrm{~V}$ & FC & 29 Oct 2017 & 0630 & 208.44 & 213.04 & 4.56 & 99.1 & Bentonite \\
\hline $75 \mathrm{~V}$ & FC & 29 Oct 2017 & 0820 & 213.04 & 214.04 & 0.86 & 86 & Seawater \\
\hline $76 \mathrm{~V}$ & FC & 29 Oct 2017 & 0940 & 214.04 & 215.04 & 0.50 & 50 & Seawater \\
\hline $77 \mathrm{~V}$ & FC & 29 Oct 2017 & 1110 & 215.04 & 216.04 & 0.82 & 82 & Seawater \\
\hline $78 \mathrm{~V}$ & FC & 29 Oct 2017 & 1230 & 216.04 & 218.84 & 2.69 & 96.1 & Seawater \\
\hline $79 \mathrm{~V}$ & FC & 29 Oct 2017 & 1410 & 218.84 & 219.84 & 0.77 & 77 & Seawater \\
\hline $80 \mathrm{~V}$ & FC & 29 Oct 2017 & 1530 & 219.84 & 220.84 & 0.93 & 93 & Seawater \\
\hline $81 \mathrm{~V}$ & FC & 29 Oct 2017 & 1715 & 220.84 & 221.84 & 0.97 & 97 & Seawater \\
\hline $82 \mathrm{~V}$ & FC & 29 Oct 2017 & 1900 & 221.84 & 223.34 & 1.17 & 78 & Seawater \\
\hline $83 \mathrm{~V}$ & FC & 29 Oct 2017 & 2120 & 223.34 & 224.34 & 0.73 & 73 & Seawater \\
\hline $84 \mathrm{R}$ & FXMCB & 29 Oct 2017 & 2340 & 224.34 & 226.14 & 2.06 & 114.4 & Seawater \\
\hline $85 \mathrm{R}$ & FXMCB & 30 Oct 2017 & 0255 & 226.14 & 228.14 & 2.75 & 137.5 & Seawater \\
\hline $86 \mathrm{R}$ & FXMCB & 30 Oct 2017 & 0550 & 228.14 & 231.64 & 3.29 & 94 & Seawater \\
\hline $87 \mathrm{R}$ & FXMCB & 30 Oct 2017 & 0820 & 231.64 & 236.14 & 4.84 & 107.6 & Seawater \\
\hline $88 \mathrm{R}$ & FXMCB & 30 Oct 2017 & 1100 & 236.14 & 240.64 & 2.88 & 64 & Seawater \\
\hline $89 \mathrm{R}$ & FXMCB & 30 Oct 2017 & 1350 & 240.64 & 244.59 & 4.61 & 116.7 & Seawater \\
\hline $90 R$ & FXMCB & 30 Oct 2017 & 1630 & 244.59 & 249.09 & 4.97 & 110.4 & Seawater \\
\hline $91 \mathrm{R}$ & FXMCB & 30 Oct 2017 & 1820 & 249.09 & 253.09 & 4.61 & 115.3 & Seawater \\
\hline $92 \mathrm{R}$ & FXMCB & 30 Oct 2017 & 2020 & 253.09 & 255.99 & 4.27 & 147.2 & Seawater \\
\hline $93 \mathrm{R}$ & FXMCB & 31 Oct 2017 & 1400 & 255.99 & 259.99 & 5.00 & 125 & Seawater \\
\hline $94 \mathrm{R}$ & FXMCB & 31 Oct 2017 & 1600 & 259.99 & 263.49 & 4.38 & 125.1 & Seawater \\
\hline $95 \mathrm{R}$ & FXMCB & 31 Oct 2017 & 1810 & 263.49 & 266.42 & 4.12 & 140.6 & Seawater \\
\hline $96 \mathrm{R}$ & FXMCB & 31 Oct 2017 & 2015 & 266.42 & 270.42 & 3.30 & 82.5 & Seawater \\
\hline $97 \mathrm{R}$ & FXMCB & 31 Oct 2017 & 2215 & 270.42 & 274.92 & 4.60 & 102.2 & Seawater \\
\hline $98 \mathrm{R}$ & FXMCB & 1 Nov 2017 & 0045 & 274.92 & 279.32 & 4.75 & 108 & Seawater \\
\hline $99 \mathrm{R}$ & FXMCB & 1 Nov 2017 & 0250 & 279.32 & 283.82 & 4.51 & 100.2 & Seawater \\
\hline $100 \mathrm{R}$ & FXMCB & 1 Nov 2017 & 0500 & 283.82 & 287.12 & 3.36 & 101.8 & Seawater \\
\hline $101 R$ & FXMCB & 1 Nov 2017 & 0725 & 287.12 & 291.62 & 4.81 & 106.9 & Seawater \\
\hline $102 \mathrm{R}$ & FXMCB & 1 Nov 2017 & 0940 & 291.62 & 296.12 & 0.29 & 6.4 & Seawater \\
\hline $103 \mathrm{R}$ & FXMCB & 1 Nov 2017 & 1115 & 296.12 & 296.92 & 1.51 & 188.8 & Seawater \\
\hline $104 \mathrm{R}$ & FXMCB & 1 Nov 2017 & 1310 & 296.92 & 298.00 & 1.77 & 163.9 & Seawater \\
\hline $105 \mathrm{R}$ & FXMCB & 1 Nov 2017 & 1615 & 298.00 & 302.50 & 0.84 & 18.7 & Seawater \\
\hline $106 \mathrm{R}$ & FXMCB & 1 Nov 2017 & 2030 & 302.50 & 306.50 & 5.05 & 126.3 & Seawater \\
\hline $107 \mathrm{R}$ & FXMCB & 1 Nov 2017 & 2230 & 306.50 & 309.50 & 2.43 & 81 & Seawater \\
\hline $108 \mathrm{R}$ & FXMCB & 2 Nov 2017 & 0045 & 309.50 & 313.00 & 4.61 & 131.7 & Seawater \\
\hline $109 \mathrm{R}$ & FXMCB & 2 Nov 2017 & 0340 & 313.00 & 316.00 & 3.16 & 105.3 & Seawater \\
\hline $110 \mathrm{R}$ & FXMCB & 2 Nov 2017 & 0710 & 316.00 & 319.90 & 4.48 & 114.9 & Seawater \\
\hline $111 \mathrm{R}$ & FXMCB & 2 Nov 2017 & 1825 & 319.90 & 324.40 & 3.12 & 69.3 & Seawater \\
\hline $112 \mathrm{R}$ & FXMCB & 2 Nov 2017 & 2035 & 324.40 & 329.40 & 4.55 & 91 & Seawater \\
\hline $113 R$ & FXMCB & 2 Nov 2017 & 2220 & 329.40 & 334.40 & 5.02 & 100.4 & Seawater \\
\hline $114 \mathrm{R}$ & FXMCB & 3 Nov 2017 & 0025 & 334.40 & 337.90 & 3.90 & 111.4 & Seawater \\
\hline $115 R$ & FXMCB & 3 Nov 2017 & 0215 & 337.90 & 342.00 & 2.55 & 62.2 & Seawater \\
\hline $116 \mathrm{R}$ & FXMCB & 3 Nov 2017 & 0435 & 342.00 & 346.99 & 2.85 & 57.1 & Seawater \\
\hline $117 \mathrm{R}$ & FXMCB & 3 Nov 2017 & 0650 & 346.99 & 351.49 & 0.70 & 15.6 & Seawater \\
\hline $118 \mathrm{R}$ & FXMCB & 3 Nov 2017 & 0925 & 351.49 & 354.53 & 3.08 & 101.3 & Seawater \\
\hline $119 \mathrm{R}$ & FXMCB & 3 Nov 2017 & 1145 & 354.53 & 358.60 & 4.18 & 102.7 & Seawater \\
\hline $120 \mathrm{R}$ & FXMCB & 3 Nov 2017 & 1515 & 358.60 & 363.60 & 4.96 & 99.2 & Seawater \\
\hline $121 R$ & FXMCB & 3 Nov 2017 & 1710 & 363.60 & 368.60 & 3.21 & 64.2 & Seawater \\
\hline $122 \mathrm{R}$ & FXMCB & 3 Nov 2017 & 1930 & 368.60 & 373.60 & 5.11 & 102.2 & Seawater \\
\hline $123 R$ & FXMCB & 3 Nov 2017 & 2150 & 373.60 & 378.60 & 2.06 & 41.2 & Seawater \\
\hline $124 R$ & FXMCB & 4 Nov 2017 & 0050 & 378.60 & 383.60 & 5.00 & 100 & Seawater \\
\hline $125 \mathrm{R}$ & FXMCB & 4 Nov 2017 & 0310 & 383.60 & 388.60 & 4.21 & 84.2 & Seawater \\
\hline $126 \mathrm{R}$ & FXMCB & 4 Nov 2017 & 0540 & 388.60 & 393.60 & 5.13 & 102.6 & Seawater \\
\hline $127 \mathrm{R}$ & FXMCB & 4 Nov 2017 & 0820 & 393.60 & 398.60 & 5.08 & 101.6 & Seawater \\
\hline $128 \mathrm{R}$ & FXMCB & 4 Nov 2017 & 1105 & 398.60 & 403.60 & 1.58 & 31.6 & Seawater \\
\hline $129 \mathrm{R}$ & FXMCB & 4 Nov 2017 & 1420 & 403.60 & 408.10 & 4.96 & 110.2 & Seawater \\
\hline $130 \mathrm{R}$ & FXMCB & 4 Nov 2017 & 1630 & 408.10 & 413.10 & 4.95 & 99 & Seawater \\
\hline $131 \mathrm{R}$ & FXMCB & 4 Nov 2017 & 1910 & 413.10 & 418.10 & 5.15 & 103 & Seawater \\
\hline $132 \mathrm{R}$ & FXMCB & 4 Nov 2017 & 2110 & 418.10 & 422.10 & 3.85 & 96.3 & Seawater \\
\hline
\end{tabular}


Table T1 (continued).

\begin{tabular}{|c|c|c|c|c|c|c|c|c|}
\hline Core & $\begin{array}{l}\text { Coring } \\
\text { method }\end{array}$ & Date & $\begin{array}{l}\text { Time EET } \\
\text { (h) }\end{array}$ & $\begin{array}{l}\text { Top } \\
\text { depth } \\
\text { (mbsf) }\end{array}$ & $\begin{array}{l}\text { Bottom } \\
\text { depth } \\
\text { (mbsf) }\end{array}$ & $\begin{array}{l}\text { Core } \\
\text { recovered } \\
(\mathrm{m})\end{array}$ & $\begin{array}{c}\text { Recovery } \\
\text { (\%) }\end{array}$ & Mud type \\
\hline $133 R$ & FXMCB & 4 Nov 2017 & 2330 & 422.10 & 424.60 & 2.65 & 106 & Seawater \\
\hline $134 R$ & FXMCB & 5 Nov 2017 & 0140 & 424.60 & 428.60 & 4.06 & 101.5 & Seawater \\
\hline $135 \mathrm{R}$ & FXMCB & 5 Nov 2017 & 0420 & 428.60 & 433.60 & 3.89 & 77.8 & Seawater \\
\hline $136 \mathrm{R}$ & FXMCB & 5 Nov 2017 & 0700 & 433.60 & 434.49 & 0.00 & 0 & Seawater \\
\hline $137 \mathrm{R}$ & FXMCB & 5 Nov 2017 & 0850 & 434.49 & 439.49 & 5.16 & 103.2 & Seawater \\
\hline $138 \mathrm{R}$ & FXMCB & 5 Nov 2017 & 1130 & 439.49 & 444.49 & 2.30 & 46 & Seawater \\
\hline $139 R$ & FXMCB & 5 Nov 2017 & 1440 & 444.49 & 449.49 & 3.00 & 60 & Seawater \\
\hline $140 \mathrm{R}$ & FXMCB & 5 Nov 2017 & 1720 & 449.49 & 454.49 & 4.81 & 96.2 & Seawater \\
\hline $141 R$ & FXMCB & 5 Nov 2017 & 2045 & 454.49 & 459.49 & 5.10 & 102 & Seawater \\
\hline $142 \mathrm{R}$ & FXMCB & 5 Nov 2017 & 2335 & 459.49 & 464.49 & 2.10 & 42 & Seawater \\
\hline $143 R$ & FXMCB & 6 Nov 2017 & 0140 & 464.49 & 465.49 & 1.39 & 139 & Seawater \\
\hline $144 R$ & FXMCB & 6 Nov 2017 & 0425 & 465.49 & 470.49 & 5.18 & 103.6 & Seawater \\
\hline $145 R$ & FXMCB & 6 Nov 2017 & 0750 & 470.49 & 475.49 & 5.19 & 103.8 & Seawater \\
\hline $146 \mathrm{R}$ & FXMCB & 6 Nov 2017 & 1045 & 475.49 & 480.49 & 4.28 & 85.6 & Seawater \\
\hline $147 \mathrm{R}$ & FXMCB & 6 Nov 2017 & 1340 & 480.49 & 485.49 & 5.15 & 103 & Seawater \\
\hline $148 \mathrm{R}$ & FXMCB & 6 Nov 2017 & 1610 & 485.49 & 490.49 & 3.74 & 74.8 & Seawater \\
\hline $149 \mathrm{R}$ & FXMCB & 6 Nov 2017 & 1840 & 490.49 & 495.50 & 5.18 & 103.4 & Seawater \\
\hline $150 R$ & FXMCB & 6 Nov 2017 & 2115 & 495.50 & 500.50 & 5.14 & 102.8 & Seawater \\
\hline $151 R$ & FXMCB & 6 Nov 2017 & 2350 & 500.50 & 505.00 & 5.19 & 115.3 & Seawater \\
\hline $152 \mathrm{R}$ & FXMCB & 7 Nov 2017 & 0340 & 505.00 & 509.50 & 5.19 & 115.3 & Seawater \\
\hline $153 R$ & FXMCB & 7 Nov 2017 & 0650 & 509.50 & 514.50 & 5.18 & 103.6 & Seawater \\
\hline $154 \mathrm{R}$ & FXMCB & 7 Nov 2017 & 1640 & 514.50 & 519.30 & 2.43 & 50.6 & Seawater \\
\hline $155 \mathrm{R}$ & FXMCB & 7 Nov 2017 & 1915 & 519.30 & 524.30 & 5.14 & 102.8 & Seawater \\
\hline $156 \mathrm{R}$ & FXMCB & 7 Nov 2017 & 2150 & 524.30 & 529.30 & 4.57 & 91.4 & Seawater \\
\hline $157 \mathrm{R}$ & FXMCB & 8 Nov 2017 & 0010 & 529.30 & 533.80 & 5.17 & 114.9 & Seawater \\
\hline $158 \mathrm{R}$ & FXMCB & 8 Nov 2017 & 0335 & 533.80 & 538.80 & 2.53 & 50.6 & Seawater \\
\hline $159 \mathrm{R}$ & FXMCB & 8 Nov 2017 & 0550 & 538.80 & 542.94 & 5.03 & 121.5 & Seawater \\
\hline $160 \mathrm{R}$ & FXMCB & 8 Nov 2017 & 0835 & 542.94 & 547.94 & 2.40 & 48 & Seawater \\
\hline $161 \mathrm{R}$ & FXMCB & 8 Nov 2017 & 1200 & 547.94 & 552.51 & 3.08 & 67.4 & Seawater \\
\hline $162 \mathrm{R}$ & FXMCB & 8 Nov 2017 & 1505 & 552.51 & 557.51 & 3.36 & 67.2 & Seawater \\
\hline $163 R$ & FXMCB & 8 Nov 2017 & 1725 & 557.51 & 562.50 & 3.50 & 70.1 & Seawater \\
\hline $164 R$ & FXMCB & 8 Nov 2017 & 2025 & 562.50 & 567.50 & 1.65 & 33 & Seawater \\
\hline $165 \mathrm{R}$ & FXMCB & 8 Nov 2017 & 2250 & 567.50 & 571.50 & 5.15 & 128.8 & Seawater \\
\hline $166 \mathrm{R}$ & FXMCB & 9 Nov 2017 & 0110 & 571.50 & 573.50 & 1.62 & 81 & Bentonite \\
\hline $167 \mathrm{R}$ & FXMCB & 9 Nov 2017 & 0425 & 573.50 & 578.50 & 4.48 & 89.6 & Seawater \\
\hline $168 \mathrm{R}$ & FXMCB & 9 Nov 2017 & 0925 & 578.50 & 583.50 & 0.84 & 16.8 & Seawater \\
\hline $169 \mathrm{R}$ & FXMCB & 9 Nov 2017 & 1225 & 583.50 & 586.00 & 1.23 & 49.2 & Seawater \\
\hline $170 \mathrm{R}$ & FXMCB & 9 Nov 2017 & 1855 & 586.00 & 591.00 & 3.00 & 60 & Seawater \\
\hline $171 R$ & FXMCB & 9 Nov 2017 & 2145 & 591.00 & 595.50 & 3.30 & 73.3 & Seawater \\
\hline $172 R$ & FXMCB & 10 Nov 2017 & 0125 & 595.50 & 600.50 & 4.60 & 92 & Seawater \\
\hline $173 R$ & FXMCB & 10 Nov 2017 & 0430 & 600.50 & 602.83 & 1.47 & 63.1 & Seawater \\
\hline $174 R$ & FXMCB & 10 Nov 2017 & 0750 & 602.83 & 605.73 & 3.00 & 103.5 & Seawater \\
\hline $175 R$ & FXMCB & 10 Nov 2017 & 1055 & 605.73 & 608.03 & 1.92 & 83.5 & Seawater \\
\hline $176 R$ & FXMCB & 10 Nov 2017 & 1335 & 608.03 & 610.43 & 2.40 & 100 & Seawater \\
\hline \multicolumn{9}{|c|}{ 381-M0078B- } \\
\hline $1 \mathrm{P}$ & FC & 12 Nov 2017 & 0200 & 0.00 & 2.00 & 1.31 & 65.5 & Seawater \\
\hline $2 \mathrm{P}$ & FC & 12 Nov 2017 & 0320 & 2.00 & 4.50 & 2.33 & 93.2 & Seawater \\
\hline $3 \mathrm{P}$ & FC & 12 Nov 2017 & 0425 & 4.50 & 6.20 & 1.66 & 97.7 & Seawater \\
\hline $4 \mathrm{P}$ & $\mathrm{FC}$ & 12 Nov 2017 & 0530 & 6.20 & 9.05 & 2.73 & 95.8 & Seawater \\
\hline $5 P$ & FC & 12 Nov 2017 & 0650 & 9.05 & 13.10 & 4.01 & 100.3 & Seawater \\
\hline $6 \mathrm{P}$ & FC & 12 Nov 2017 & 0745 & 13.10 & 16.20 & 3.05 & 98.4 & Seawater \\
\hline $7 \mathrm{P}$ & FC & 12 Nov 2017 & 0835 & 16.20 & 19.20 & 3.00 & 100 & Seawater \\
\hline $8 \mathrm{P}$ & FC & 12 Nov 2017 & 0935 & 19.20 & 22.95 & 3.70 & 98.7 & Seawater \\
\hline $9 \mathrm{P}$ & FC & 12 Nov 2017 & 1030 & 22.95 & 27.65 & 4.41 & 93.8 & Seawater \\
\hline $10 \mathrm{P}$ & FC & 12 Nov 2017 & 1140 & 27.65 & 32.35 & 4.40 & 93.6 & Seawater \\
\hline $11 \mathrm{P}$ & FC & 12 Nov 2017 & 1300 & 32.35 & 37.05 & 4.24 & 90.2 & Seawater \\
\hline $12 \mathrm{P}$ & FC & 12 Nov 2017 & 1400 & 37.05 & 41.75 & 4.30 & 91.5 & Seawater \\
\hline $13 \mathrm{P}$ & FC & 12 Nov 2017 & 1445 & 41.75 & 46.45 & 4.38 & 93.2 & Seawater \\
\hline $14 \mathrm{P}$ & FC & 12 Nov 2017 & 1545 & 46.45 & 51.15 & 4.26 & 90.6 & Seawater \\
\hline $15 \mathrm{P}$ & FC & 12 Nov 2017 & 1640 & 51.15 & 55.85 & 4.39 & 93.4 & Seawater \\
\hline
\end{tabular}

Coring continued with good rates of advance and recovery for the next 3 days until a communications and power issue arose with the SEADEVIL, resulting in its recovery on deck at $0530 \mathrm{~h}$ on $2 \mathrm{No}-$ vember for further assessment. It was concluded that this issue required a significant amount of time to resolve; therefore, it was agreed that coring would continue without the use of the SEADEVIL. From this point onward, the basic SBF was used for coring without the additional support of the SEADEVIL. Coring began again at $1645 \mathrm{~h}$ and progressed well through 7 November. 
On 7 November, coring operations were paused because a slip clamp became jammed around the drill string. The clamp was eventually released after approximately $7 \mathrm{~h}$. Coring then recommenced and continued through 8 November (apart from $1 \mathrm{~h}$ of downtime for lightning).

On the morning of 9 November, drill floor maintenance was required to repair some disk springs on the FXMCB. At $\sim 0545 \mathrm{~h}$, a slip clamp jammed around the drill string again, and it was not released until $0710 \mathrm{~h}$, after which coring resumed. Coring paused again at $1135 \mathrm{~h}$ when the FXMCB was recovered on deck to undergo repairs. At $1600 \mathrm{~h}$, coring resumed and progressed well through the morning of 10 November. At 1335 h, the final Hole M0078A core was on deck with a total penetration of $610.43 \mathrm{mbsf}$.

Throughout coring operations in Hole M0078A, seawater was used as the drilling medium, with the exception of four core runs where bentonite drilling mud was used to assist with hole conditioning (removal of cuttings and reducing any swelling of the borehole sidewall) (see Table T1).

Downhole logging operations in Hole M0078A commenced following coring and continued through 12 November. See Logging operations below for details.

\section{Hole M0078B}

Following unsuccessful downhole logging (see below), the decision was made to bump over $20 \mathrm{~m}$ to drill a short "B" hole to capture intervals of the upper $50 \mathrm{~m}$ of stratigraphy that were not recovered from Hole M0078A. Pipe was tripped, and the vessel moved $20 \mathrm{~m}$ south to the new coordinates $\left(38^{\circ} 8^{\prime} 41.144^{\prime \prime} \mathrm{N}, 22^{\circ} 45^{\prime} 30.242^{\prime \prime} \mathrm{E}\right.$ ) (Figure F3).

At midnight on 12 November 2017, the Fugro Synergy was settling on site. The first core was recovered at $0200 \mathrm{~h}$ using the Fugro Corer in push mode (a $1.31 \mathrm{~m}$ core that captured the seabed/water interface), and coring continued throughout the day with good recovery until $1640 \mathrm{~h}$, when coring operations ended at $55.85 \mathrm{mbsf}$. Seawater was used as the drilling medium throughout coring operations in Hole M0078B. Following the completion of coring, tripping pipe commenced, and the SBF was recovered on deck in preparation for transit to the port call. At 0400 h on 13 November, the Fugro Synergy departed Site M0078 for the pilot station and was alongside and tied up by $0630 \mathrm{~h}$ at the Port of Corinth.

\section{Logging operations}

The following wireline logging tools were planned for deployment in two depth stages: magnetic susceptibility and conductivity (EM51), dual laterolog resistivity (DLL3), stacked natural gamma ray (QL40SGR), sonic (QL40FWS), acoustic borehole televiewer (QL40ABI), and spectral gamma ray (ASGR512).

\section{Hole M0078A}

Following completion of coring in Hole M0078A on 10 November 2017, preparations were made for downhole logging. Hole M0078A was stabilized with weighted bentonite mud, and then the drill pipe was raised to 296.54 mbsf for the first phase of logging.

Logging with the EM51 tool began at $0028 \mathrm{~h}$ on 11 November. The logging tools utilized for this expedition were super-slimline, and the tool strings were consequently relatively light. The light tool strings, coupled with the density of the mud that was ultimately used to stabilize the borehole, made it difficult for the tool string to descend in the borehole. Because of concerns surrounding hole stability, it was necessary to circulate heavier mud $(8.5 \mathrm{lb} / \mathrm{gal})$, which further impeded the descent of the tool string. After several failed
Figure F3. Hole M0078A and M0078B locations.

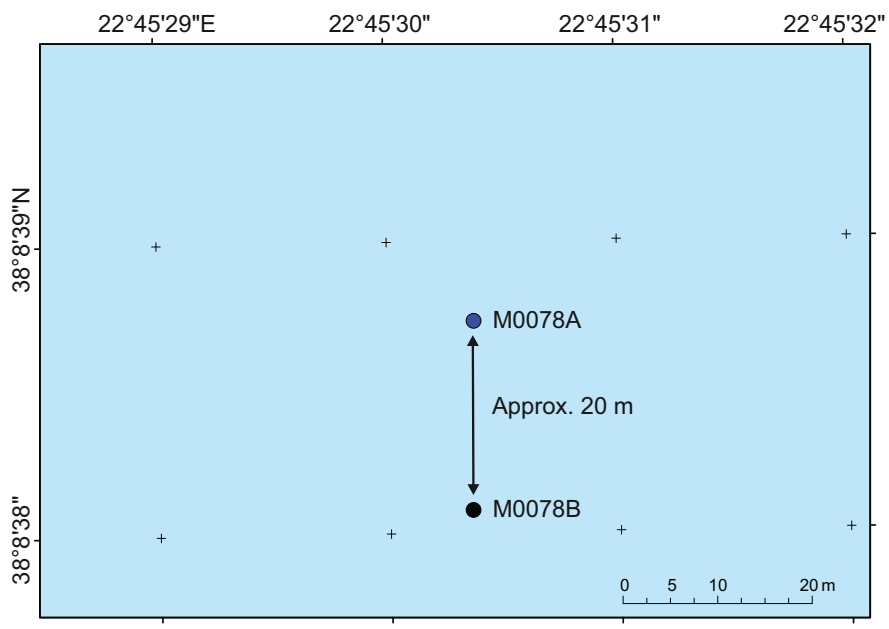

attempts to deploy the tool, additional weight $(\sim 15 \mathrm{~kg})$ was clamped to the wireline cable above the tool to make it heavier. The weighted tool started its descent more easily than before, but several losses of tension were observed, including at $297 \mathrm{~m}$ wireline log depth below seafloor (WSF), the depth of the drill bit, and between 337 and 347 $\mathrm{m}$ WSF. The total depth reached by the tool was believed to be 607 $\mathrm{m}$ WSF, and logging uphole commenced at a speed of $22 \mathrm{~m} / \mathrm{min}$. The difficulties encountered during the descent, including repeated attempts to pass various tight spots, led to the logging cable becoming entangled around the tool. As a result, $100 \mathrm{~m}$ of logging cable had to be cut from the primary winch (GV550). Data acquired during this first run are not depth accurate because of the entangling of the cable, and owing to the nature of the measurement (electrical and magnetic), the same entangled cable passing along the tool strongly affected the recorded data. Therefore, these data were not processed.

To save operational time, the backup winch (RG2000) was set up and used for the remainder of logging operations in Hole M0078A. To address the issues encountered during the first run, a heavier, centralized stacked tool string that included the QL40SGR, QL40FWS, and QL40ABI tools was deployed. No difficulties were encountered during the descent in the drill pipe. However, the tool string could not pass through the bit into the open hole, presumably because of the passive bowspring centralizers. The tool string was recovered, and a longer, heavier tool string was deployed in its place without the bowspring centralizers and with the QL40SGR, QL40FWS, caliper (QL40CAL), and magnetic susceptibility (QL40MSUS) tools. This tool string successfully reached $607 \mathrm{~m}$ WSF, and logging uphole started at $4 \mathrm{~m} / \mathrm{min}$. Unfortunately, the tool string became stuck in the open hole ( $356 \mathrm{~m} \mathrm{WSF}$ ) during its ascent. For $6 \mathrm{~h}$, multiple attempts were made to free the tool string from the borehole, with increasing load applied to the cable in a step-wise fashion. Ultimately, it became clear that recovery of the tool string might not be possible, and the breaking load of the tool head was exceeded, resulting in the abandonment of the tool string in the hole. Fishing operations were not attempted, and logging operations in Hole M0078A were concluded at 1910 h on 11 November.

Data recorded during the final run indicate that the tool string became stuck on multiple occasions during its ascent, suggesting that borehole conditions were likely deteriorating as logging operations progressed. Owing to the difficulties encountered and erratic 
tool responses and in the absence of a meaningful depth reference, data lack context and are unusable.

\section{Hole M0078B}

Because of the shallow penetration $(55.85 \mathrm{mbsf})$ in Hole M0078B, it was not logged.

\section{Lithostratigraphy}

Site M0078 is divided into two major lithostratigraphic units (1 and 2) based on a combination of the component facies associations (FA; see the Expedition $\mathbf{3 8 1}$ facies associations chapter [McNeill et al., 2019a]; Table T2), paleontology, seismic facies, and physical properties. In the following sections, we describe the units and subunits at Site M0078 and their boundaries (Table T3). The upper lithostratigraphic unit (1) is divided into 16 subunits that correlate with marine and isolated/semi-isolated intervals.

\section{Unit and subunit description}

Site M0078 was drilled into a horst block to sample the two main seismic stratigraphic units, here designated as lithostratigraphic Unit 1 (seismic Unit 2) and the underlying Unit 2 (seismic Unit 1) (Figure F2). Unit 1 is further divided into 16 subunits (Figure F4).

Sediment composition for both Units 1 and 2 was determined from smear slide analysis and X-ray diffraction (XRD) data (Figure F5). Unit 1 sediment is dominated by detrital clay to clayey silt with calcite most abundant and with common to abundant quartz, feldspar, and phyllosilicates. Overall, carbonate content increases from the seafloor to the base of Hole M0078A (from $<50$ to $>75 \mathrm{wt} \%$ ), with a corresponding decrease in quartz and clay abundance. The upper $100 \mathrm{~m}$ of Hole M0078A displays particularly high mineral diversity, with dominant carbonate minerals, quartz, and phyllosilicates (clays and micas). Continuing downhole, carbonate minerals (mainly represented by calcite) gradually become more abundant with respect to other minerals. Biogenic material is common, where the major component is individual diatoms and diatom fragments (Figure F5C). Foraminifers, foraminiferal fragments, and calcareous nannofossils are common in the homogeneous finegrained intervals of FA1 and FA6 mud (see Micropaleontology) but are rare to absent in other facies associations. A distinctive compositional feature is that well-sorted silt-sized aragonite needles dominate some of the FA3 white laminations (Figure F5B). However, it is important to note that white laminations can also be composed of calcite and thus are not always indicative of aragonite. Organic components and pyrite are also commonly present in smear slides, but their overall contribution to the mineral assemblage is negligible. In sandy intervals, subangular to subrounded, reworked detrital calcite grains dominate. Unit 2 has a similar overall composition to Unit 1 , according to XRD analysis (Figure F5A), but with carbonate as the dominant component throughout and less quartz and fewer phyllosilicates. Smear slide analysis indicates that the carbonate is generally in the form of well-sorted clay (mud)-grade to very fine siltsized detrital calcite (Figure F5D). Other detrital grains and organic and biogenic components are generally rare or absent in Unit 2.

Tephra and cryptotephra intervals were found in Site M0078 cores. These intervals were identified by a combination of visual inspection and physical properties. An increase in Multi-Sensor Core Logger (MSCL) natural gamma radiation (NGR) intensity was usually observed in association with both visible tephra layers and
Table T2. Definitions of facies associations used in lithostratigraphic interpretation, Expedition 381. Download table in CSV format.

\begin{tabular}{|c|c|}
\hline $\begin{array}{l}\text { Facies } \\
\text { association }\end{array}$ & Definition \\
\hline FA1 & Homogeneous mud \\
\hline FA2 & $\begin{array}{l}\text { Greenish gray mud with dark gray to black mud to sand beds and } \\
\text { laminations }\end{array}$ \\
\hline FA3 & Light gray to white laminations alternating with mud and silt beds \\
\hline FA4 & Laminated greenish gray to gray mud with mud beds \\
\hline FA5 & Greenish gray mud with homogeneous centimeter-thick gray mud beds \\
\hline FA6 & Green bedded partly bioturbated mud, silt, and sand \\
\hline FA7 & $\begin{array}{l}\text { Clast-supported sandy conglomerates and pebbly reddish brown sand with } \\
\text { silt }\end{array}$ \\
\hline FA8 & $\begin{array}{l}\text { Reddish brown to brownish gray mud and/or silt, including mottled } \\
\text { textures and rootlets }\end{array}$ \\
\hline FA9 & Green-gray, often pebbly sandstone/siltstone \\
\hline FA10 & Interbedded mud/silt and decimeter-thick sand beds \\
\hline FA11 & Interbedded mud/silt and centimeter-thick sand beds \\
\hline FA12 & Light gray to buff homogeneous to weakly stratified bioturbated mud \\
\hline FA13 & Contorted bedding and mud-supported sand and conglomerates \\
\hline FA14 & Greenish gray pebbly silt and clast-supported fining-upward conglomerates \\
\hline FA15 & $\begin{array}{l}\text { Greenish to buff bioclastic laminated siltstone to bedded fine sandstone, } \\
\text { including bioturbation, ostracods, and rootlets }\end{array}$ \\
\hline FA16 & Greenish to buff bedded and bioturbated bioclastic sandstone to mudstone \\
\hline FA17 & $\begin{array}{l}\text { Greenish laminated to faintly bedded/homogeneous fossiliferous } \\
\text { mudstone }\end{array}$ \\
\hline
\end{tabular}

Table T3. Lithostratigraphic unit and subunit boundary top depths, Site M0078. Download table in CSV format.

\begin{tabular}{|c|c|c|}
\hline Lith. unit & Subunit & $\begin{array}{l}\text { Top depth } \\
\text { (mbsf) }\end{array}$ \\
\hline \multicolumn{3}{|c|}{ Hole M0078A } \\
\hline \multirow[t]{16}{*}{1} & 1 & 0.00 \\
\hline & 2 & 20.78 \\
\hline & 3 & 94.14 \\
\hline & 4 & 122.16 \\
\hline & 5 & 180.14 \\
\hline & 6 & 188.18 \\
\hline & 7 & 199.14 \\
\hline & 8 & 206.40 \\
\hline & 9 & 236.18 \\
\hline & 10 & 260.70 \\
\hline & 11 & 287.12 \\
\hline & 12 & 298.84 \\
\hline & 13 & 322.35 \\
\hline & 14 & 334.40 \\
\hline & 15 & 366.49 \\
\hline & 16 & 369.66 \\
\hline \multicolumn{2}{|l|}{2} & 385.14 \\
\hline \multicolumn{2}{|c|}{ Bottom of hole } & 610.43 \\
\hline \multicolumn{3}{|c|}{ Hole M0078B } \\
\hline \multirow[t]{2}{*}{1} & 1 & 0.00 \\
\hline & 2 & 21.16 \\
\hline \multicolumn{2}{|c|}{ Bottom of hole } & 55.49 \\
\hline
\end{tabular}

cryptotephra intervals, and this relationship was used as the primary method for targeting further investigation. Distinct and visible tephra layers (e.g., Section 381-M0078A-121R-3, 42.0-43.0 cm [366.52-366.53 mbsf]) were usually a subtly different color from the surrounding sediment, and very high concentrations of bubble-wall shards in these layers made the layers highly reflective under hand lens inspection. Cryptotephra intervals comprise the majority of tephra identified in the core and were identifiable only through methodical sampling of NGR intensity peaks and subsequent visual ex- 
Figure F4. Composite stratigraphic log. FA = facies association, Biot. int. = bioturbation intensity, MS = magnetic susceptibility. Lithostratigraphic subunits in Unit 1: blue $=$ marine, green $=$ isolated/semi-isolated. A. Legend. B. 0-300 mbsf, Hole M0078A. (Continued on next 2 pages.)

A

Legend

Facies associations

FA1: Homogeneous mud

FA2: Greenish gray mud with dark gray to black mud to sand beds and laminations

FA3: Light gray to white laminations alternating with mud and silt beds

FA4: Laminated greenish gray to gray mud with mud beds

FA5: Greenish gray mud with homogeneous centimeter-thick gray mud beds

FA6: Green bedded partly bioturbated mud, silt, and sand

FA7: Clast-supported sandy conglomerates and pebbly reddish brown sand with silt

FA8: Reddish brown to brownish gray mud and/or silt, including mottled textures and rootlets

FA9: Green-gray, often pebbly sandstone/siltstone

FA10: Interbedded mud/silt and decimeter-thick sand beds

FA11: Interbedded mud/silt and centimeter-thick sand beds

FA12: Light gray to buff homogeneous to weakly stratified bioturbated mud

FA13: Contorted bedding and mud-supported sand and conglomerates

FA14: Greenish gray pebbly silt and clast-supported fining-upward conglomerates

FA15: Greenish to buff bioclastic laminated siltstone to bedded fine sandstone, including bioturbation, ostracods, and rootlets

FA16: Greenish to buff bedded and bioturbated bioclastic sandstone to mudstone

FA17: Greenish laminated to faintly bedded/homogeneous fossiliferous mudstone

Tephra containing layers

Coupled sand + homogeneous mud

【 $>75 \mathrm{~cm}$

I $25-75 \mathrm{~cm}$

I $10-25 \mathrm{~cm}$
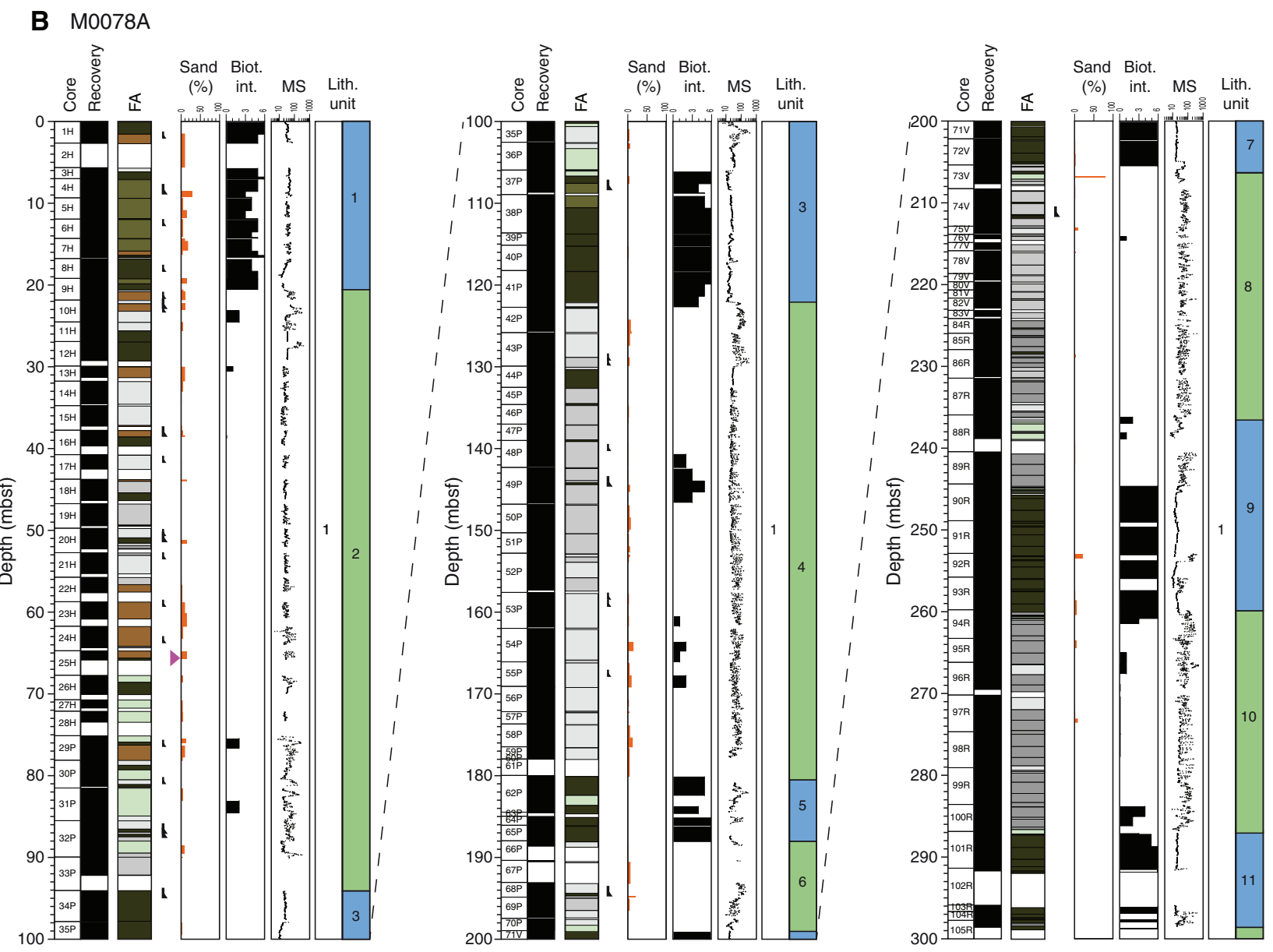
Figure F4 (continued). C. 300-610.43 mbsf (base of hole), Hole M0078A. Unit 2 color is purely for visual differentiation and does not have any paleoenvironmental meaning. (Continued on next page.)

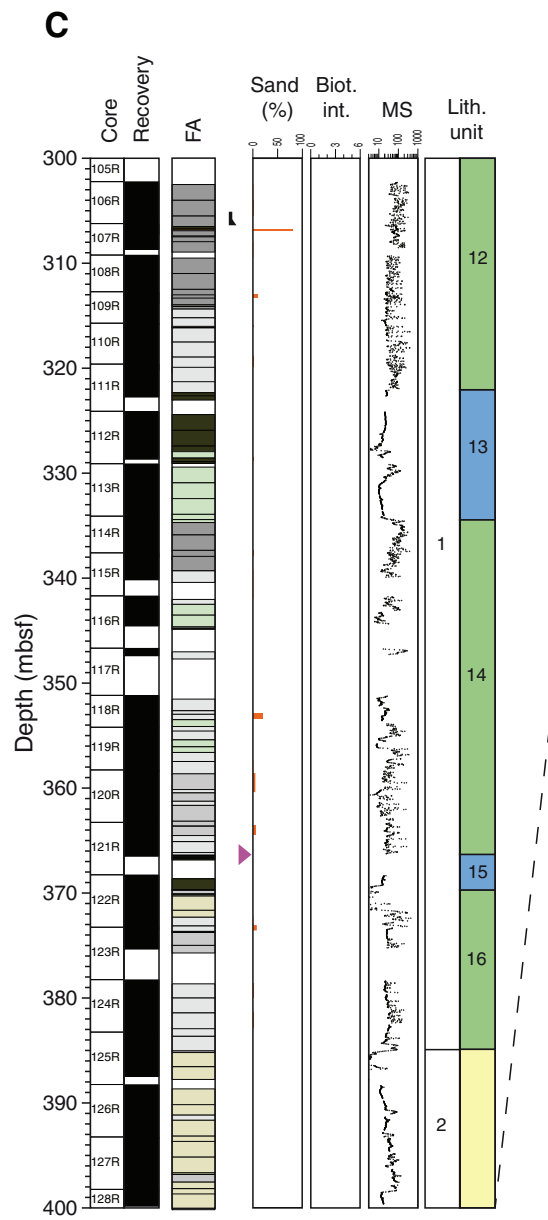

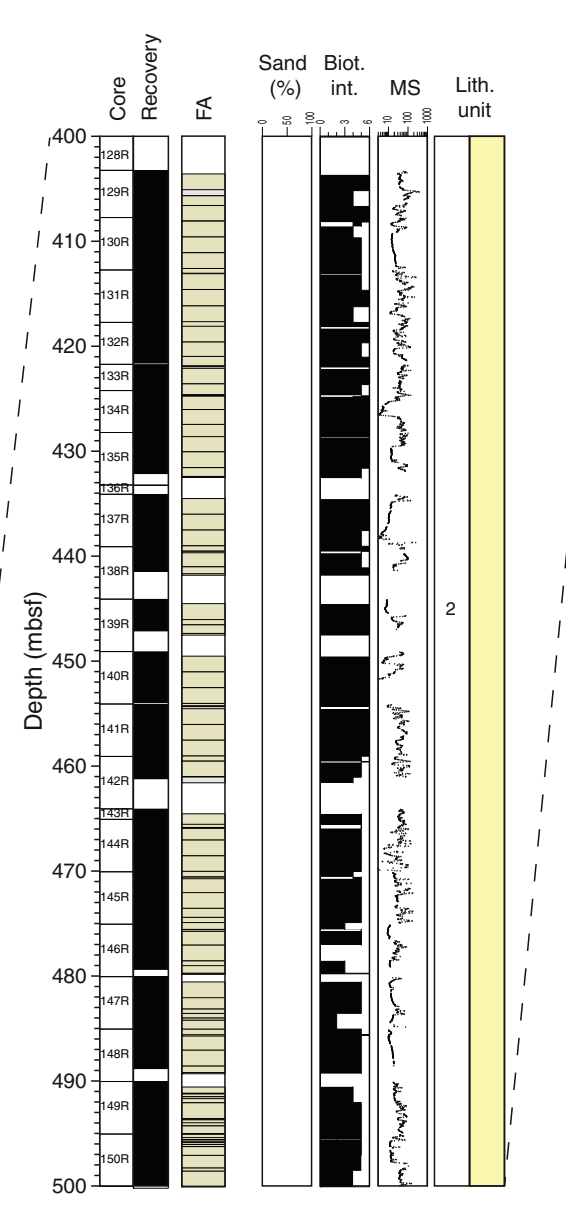

amination of sampled material via optical microscopy. Cryptotephra were also identified incidentally during routine micropaleontological work by the observation of glass shards.

\section{Unit 1}

Intervals: $381-\mathrm{M} 0078 \mathrm{~A}-1 \mathrm{H}-1,0 \mathrm{~cm}$, to $125 \mathrm{R}-2,15 \mathrm{~cm}$; $381-$ M0078B-1H-1, $0 \mathrm{~cm}$, to $15 \mathrm{P}-\mathrm{CC}, 15 \mathrm{~cm}$

Depths: Hole M0078A = 0-385.14 mbsf; Hole M0078B = 0$55.49 \mathrm{mbsf}$ (base of Unit 1 not reached)

Age: Pleistocene to Holocene

\section{Subunit 1-1}

Intervals: 381-M0078A-1H-1, $0 \mathrm{~cm}$, to $9 \mathrm{H}-2,26 \mathrm{~cm}$; 381M0078B-1H-1, $0 \mathrm{~cm}$, to $8 \mathrm{H}-2,46 \mathrm{~cm}$

Depths: Hole M0078A = 0-20.78 mbsf (20.78 m thick including $3.22 \mathrm{~m}$ of missing core); Hole M0078B $=0-21.16 \mathrm{mbsf}$ (21.16 $\mathrm{m}$ thick including $1.07 \mathrm{~m}$ of missing core)

In Hole M0078A, Subunit 1-1 extends from the seafloor to Section $9 \mathrm{H}-2,26 \mathrm{~cm}$ (20.78 mbsf), where its base is marked by a change from mainly FA1 greenish gray homogeneous mud to FA4 laminated mud beds with greenish gray parallel laminations (Figure F4). In Hole M0078B, Subunit 1-1 extends from the seafloor to Section $8 \mathrm{H}-2,46 \mathrm{~cm}$, where its base is also marked by a transition from FA1

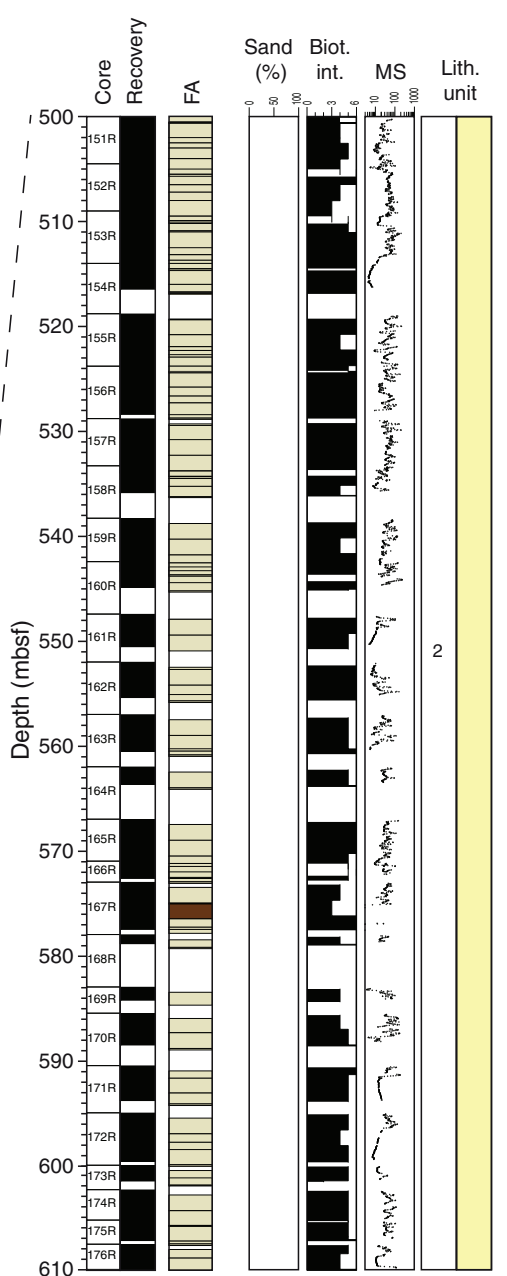

to FA4. In Subunit 1-1, four sand-homogeneous mud couplets $>10$ $\mathrm{cm}$ thick were identified in Hole M0078A and six were identified in Hole M0078B.

In Hole M0078A, Subunit 1-1 consists of FA1 and FA6 mud and minor FA11 interbedded mud/silt beds. The upper part comprises FA1 greenish gray homogeneous mud and FA6 mud with faint laminations and bedding, as well as high bioturbation intensity $(\mathrm{BI}=4-$ 6, including discrete Planolites and Palaeophycus). Subordinate centimeter-scale sand beds that fine upward, typically over 5-10 $\mathrm{cm}$, also occur. The lower part is dominated by FA1 greenish gray homogeneous mud with shell fragments and intense bioturbation (BI = 4-6, with Zoophycos and Scolicia). Four prominent sand-homogeneous mud couplets were identified throughout Subunit 1-1 in Hole M0078A.

In Hole M0078B, Subunit 1-1 also comprises FA1 and FA6.

\section{Subunit 1-2}

Intervals: 381-M0078A-9H-2, $26 \mathrm{~cm}$, to 34P-1, $0 \mathrm{~cm}$; 381M0078B-8H-2, $46 \mathrm{~cm}$, to $15 \mathrm{P}-\mathrm{CC}, 15 \mathrm{~cm}$

Depths: Hole M0078A = 20.78-94.14 mbsf (73.36 m thick including $14.90 \mathrm{~m}$ of missing core); Hole M0078B = 21.1655.49 mbsf (34.33 m penetrated including $2.57 \mathrm{~m}$ of missing core; base Subunit 1-2 not reached) 
Figure F4 (continued). D. Hole M0078B.

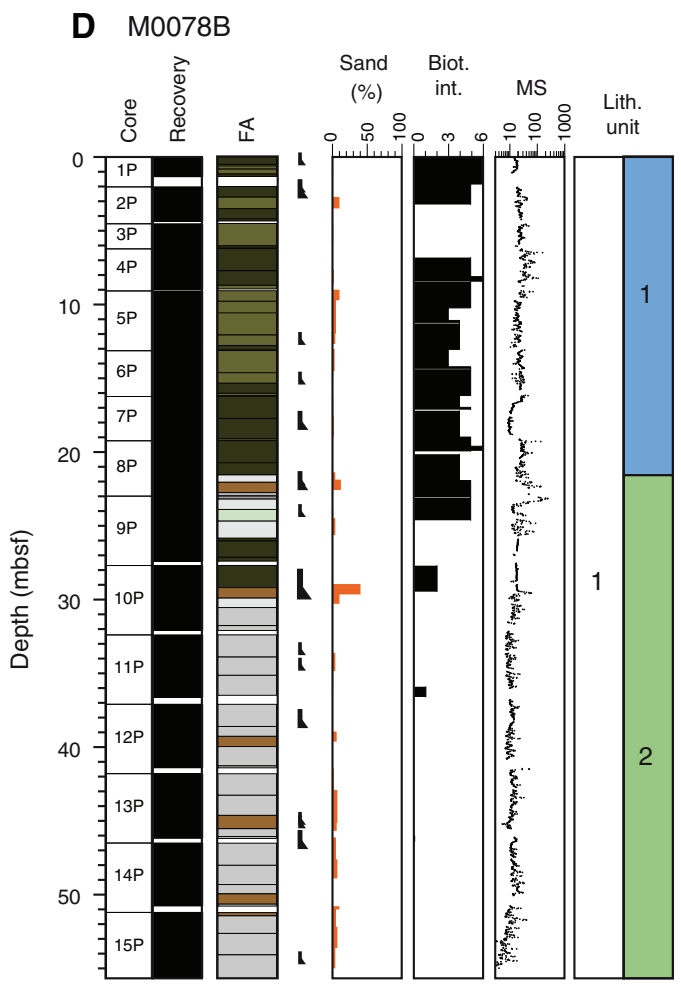

The top of Subunit 1-2 is marked by a change from FA1 (above) to FA4 (below). The lower boundary with Subunit 1-3 is transitional and occurs in FA1 homogeneous mud, and it is marked by the appearance of marine microfossils and shell fragments (Figure F4). In Hole M0078A, 15 sand-homogeneous mud couplets occur in Subunit 1-2. In Hole M0078B, 11 sand-homogeneous mud couplets are dispersed throughout Subunit 1-2, with a notable $4 \mathrm{~m}$ thick example from Section 9P-5, $16 \mathrm{~cm}$, to Section 10P-2, $71 \mathrm{~cm}$ (25.81-19.86 mbsf).

In Hole M0078A, Subunit 1-2 consists of a complex succession of five facies associations and comprises three parts marked by changes in the dominant facies association. The upper part (Sections $9 \mathrm{H}-2,26 \mathrm{~cm}$, to $22 \mathrm{H}-2,0 \mathrm{~cm} ; 20.58-56.66 \mathrm{mbsf}$ ) is dominated by FA4 laminated mud beds with greenish gray parallel laminations that often alternate with FA5 greenish gray mud with homogeneous centimeter-scale mud beds and FA1 homogeneous mud. A smaller percentage of FA11 interbedded mud/silt beds and centimeter-thick sand beds (sometimes graded) occurs in the upper part of Subunit 1-2 (e.g., Section $13 \mathrm{H}-1,36 \mathrm{~cm} ; 30.3 \mathrm{mbsf}$ ). The middle part of Subunit 1-2 (Sections $22 \mathrm{H}-2,0 \mathrm{~cm}$, to $32 \mathrm{P}-3,96 \mathrm{~cm} ; 56.66-89.5 \mathrm{mbsf}$ ) is characterized by a general increase in sand proportion. It comprises predominantly FA3 bedded mud with gray to white submillimeterscale laminations that are interbedded with FA11 mud and sand beds. The lower part of Subunit 1-2 (Sections 32P-3, $96 \mathrm{~cm}$, to 34P$1,0 \mathrm{~cm} ; 89.5-94.14 \mathrm{mbsf}$ ) mainly consists of FA4 interbedded with short FA1 and FA3 intervals.

Subunit 1-2 is incomplete in Hole M0078B. The upper part consists of FA4, FA11, FA2, FA3, FA1, and FA10 intervals. Below Section $10 \mathrm{P}-3,0 \mathrm{~cm}$ (24.65 mbsf), FA5 predominates. Some reddish mud appears in FA5 in Sections 381-M0078B-15P-2, $75 \mathrm{~cm}$, to 15P$3,68 \mathrm{~cm}(53.3-54.69 \mathrm{mbsf})$.

\section{Subunit 1-3}

Interval: $381-\mathrm{M} 0078 \mathrm{~A}-34 \mathrm{P}-1,0 \mathrm{~cm}$, to $41 \mathrm{P}-3,84 \mathrm{~cm}$

Depth: $94.14-122.16 \mathrm{mbsf}$ (28.02 $\mathrm{m}$ thick including $0.53 \mathrm{~m}$ of missing core)

The top of Subunit 1-3 is placed at the top of Core 381M0078A-34P, where the uppermost part is composed of FA1 homogeneous mud. However, poor recovery in the overlying core means that the exact boundary location is poorly constrained. The base is marked by a change from FA1 (above) to FA4 (below) (Figure F4). Two sand-homogeneous mud couplets occur in Subunit 1-3.

Subunit 1-3 is divided into three parts. The upper part, to Section 381-M0078A-35P-2, $74 \mathrm{~cm}$ (100.19 mbsf), comprises FA1 greenish gray mud with abundant shell fragments and pyrite and sparse thin silty and sandy beds. Below, a transition to the second part includes mixed FA3 and FA4 laminated deposits and then a marked change to FA3 in Section 36P-1, $64 \mathrm{~cm}$ (103.28 mbsf). The FA3 laminations are regular and millimeter or submillimeter in scale and contain both marine and brackish diatom assemblages (see Micropaleontology), with aragonite dominating the whitish laminations (Figure F5B). An abrupt contact in Section 37P-1, 62 $\mathrm{cm}$ (106.66 mbsf), marks the top of the lower part of Subunit 1-3, which is dominated by FA1 homogeneous mud. The homogeneous character is due to a high degree of bioturbation destroying any bedding or lamination.

\section{Subunit 1-4}

Interval: $381-\mathrm{M} 0078 \mathrm{~A}-41 \mathrm{P}-3,84 \mathrm{~cm}$, to $62 \mathrm{P}-1,0 \mathrm{~cm}$

Depth: $122.16-180.14 \mathrm{mbsf}$ (57.98 m thick including $3.38 \mathrm{~m}$ of missing core)

The top of Subunit 1-4 is marked by a change from FA1 homogeneous mud to FA4 laminated mud. The lower boundary is marked by a change from FA4 to FA1 (Figure F4). Seven sand-homogeneous mud couplets occur in Subunit 1-4.

Subunit 1-4 comprises two parts, each dominated by one facies, with a transitional boundary between them in Section 381M0078A-53P-1, $0 \mathrm{~cm}$ (157.74 mbsf). Below a package dominated by FA4, much of the upper part of Subunit 1-4 (128.84-157.74 mbsf) is dominated by FA 5 but also includes FA1 occurrences of bioturbated mud as thick as $3 \mathrm{~m}$. In the FA5 sediment, frequent centimeter-thick intervals consist of very poorly sorted silty sand with subangular to subrounded grains dominated by detrital lithics (mainly carbonates and quartz) and common organic material. The homogeneous mud beds (FA1) have gray to reddish gray ( $7.5 \mathrm{Y} 5 / 2$ to $7.5 \mathrm{Y} 6 / 2$ ) color variations. Shell fragments were also observed in the upper part of Subunit 1-4. The mud beds occasionally include darker gray organic-rich laminations. In the lower $5 \mathrm{~m}$ of the upper part of Subunit 1-4, bedded mud (FA5) is interbedded with laminated mud (FA4) on a meter scale.

The lower part of Subunit 1-4 (Sections 381-M0078A-53P-1, 0 $\mathrm{cm}$, to $62 \mathrm{P}-1,0 \mathrm{~cm} ; 157.74-180.14 \mathrm{mbsf}$ ) mostly consists of FA4 with minor FA5 occurrences over intervals of tens of centimeters (165.89-166.24 mbsf; 172.16-172.34 mbsf).

\section{Subunit 1-5}

Interval: 381-M0078A-62P-1, $0 \mathrm{~cm}$, to 65P-CC, $8 \mathrm{~cm}$

Depth: $180.14-188.18 \mathrm{mbsf}$ (8.18 $\mathrm{m}$ thick including $0.57 \mathrm{~m}$ of missing core) 
Figure F5. A. Downhole major mineral distribution from XRD data, Hole M0078A. B. Calcareous silt showing well-sorted elongated aragonite needles (36P-CC, $13-14 \mathrm{~cm})$. C. Silt showing poorly sorted, subangular to subrounded biogenic grains (121R-CC, 12-13 cm). D. Calcareous clayey silt dominated by moderately to well-sorted, subrounded calcite mineral grains $(153 \mathrm{R}-\mathrm{CC}, 14-15 \mathrm{~cm})$.

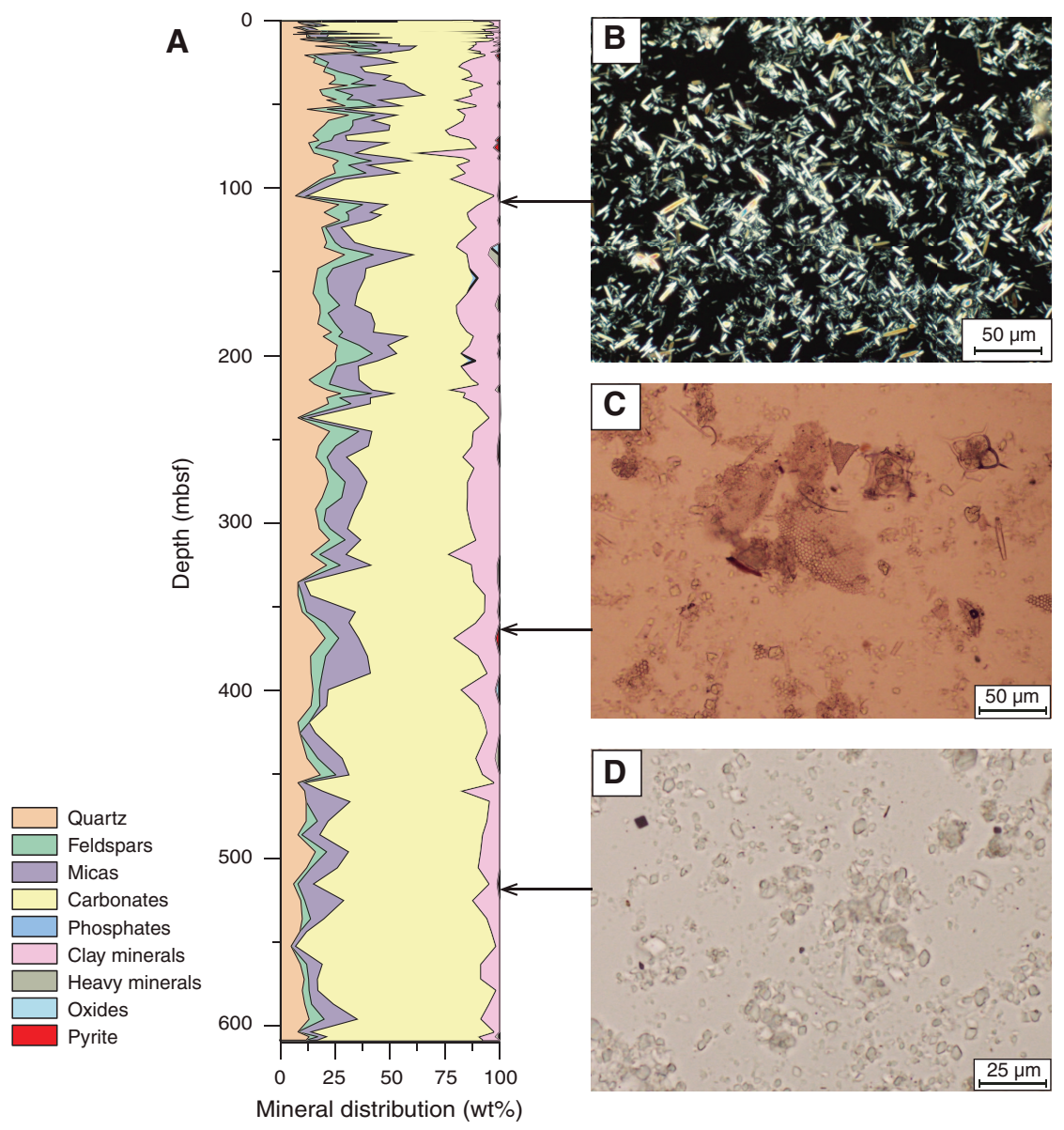

FA1 homogeneous mud appears in Section 381-M0078A-62P-1, $0 \mathrm{~cm}$ (180.14 mbsf), marking the top of Subunit 1-5. However, approximately $2 \mathrm{~m}$ of core is missing immediately above this core, and therefore the top of Subunit 1-5 is poorly constrained. The lower boundary marks a change from greenish gray homogeneous mud (FA1) to laminated mud (FA4) (Figure F4).

The predominant facies association in Subunit 1-5 is greenish gray homogeneous mud (FA1) with high levels of bioturbation, scattered sparse small shell fragments, some rare faint laminations, and scattered pyrite. This facies association is interrupted by a $122 \mathrm{~cm}$ thick succession of FA3 gray and cream finely laminated mud with a few 1-2 cm beds of homogeneous mud that occurs with a disturbed top in Section 381-M0078A-62P-2, $147 \mathrm{~cm}$, and a sharp base in Section $62 \mathrm{P}-3,120 \mathrm{~cm}(182.3-183.52 \mathrm{mbsf})$. The laminations in this interval comprise well-sorted silt-grade aragonite crystals with abundant framboidal pyrite. Bioturbation intensity appears low.

\section{Subunit 1-6}

Interval: 381-M0078A-66P-1, $0 \mathrm{~cm}$, to $70 \mathrm{P}-1,148 \mathrm{~cm}$

Depth: $188.18-199.14 \mathrm{mbsf}$ (10.96 m thick including $4.29 \mathrm{~m}$ of missing core)
The top of Subunit 1-6 is marked by the disappearance of marine microfossils (see Micropaleontology) and a change from FA1 homogeneous mud (above) to FA4 laminated greenish gray mud (below) (Figure F4). The nature of the boundary is unclear because it falls in the $\sim 8 \mathrm{~cm}$ gap (no recovery) between cores. The lower boundary is marked by the reappearance of marine microfossils and a change from FA3 creamy laminated mud (above) to FA1 homogeneous mud (below). One sand-homogeneous mud couplet occurs in Subunit 1-6.

The top part of Subunit 1-6 consists of FA4 centimeter-scale interbedded laminated and homogeneous mud beds. Black organicrich silt layers (millimeter scale) are found occasionally throughout, whereas very fine sand beds are rare and thin $(<1 \mathrm{~cm}$ thick) where present. Rare pyrite is scattered throughout. A $32 \mathrm{~cm}$ interval of FA1 homogeneous mud containing abundant pyrite beginning in Section 381-M0078A-68P-2, $20 \mathrm{~cm}$ (194.45 mbsf), separates the top part from the rest of the subunit. Below the homogeneous mud interval is another section of FA4 centimeter-scale interbedded laminated mud and homogeneous mud beds (70\%) with lesser proportions of FA5 (30\%). This interval also features rare $0.5-1.5$ $\mathrm{cm}$ thick fine sand and millimeter-scale black organic-rich silt. Rare pyrite is scattered throughout this interval. The lower $78 \mathrm{~cm}$ of the 
subunit consists of FA3 creamy laminated mud interbedded with homogeneous mud beds.

\section{Subunit 1-7}

Interval: $381-\mathrm{M} 0078 \mathrm{~A}-71 \mathrm{~V}-1,0 \mathrm{~cm}$, to $73 \mathrm{~V}-1,86 \mathrm{~cm}$

Depth: 199.14-206.40 mbsf (7.26 m thick including $0.06 \mathrm{~m}$ of missing core)

The top of Subunit 1-7 is marked by a distinct boundary between overlying FA3 creamy laminated mud and underlying FA1 homogeneous mud (Figure F4). The base is marked by the appearance of laminations that represent a return to FA3 creamy laminated mud at the top of the underlying Subunit 1-8 (Figure F6).

The upper part of Subunit 1-7 consists of greenish gray homogeneous mud (FA1) with shell fragments and bioclasts scattered throughout. The homogeneous mud is variably bioturbated and becomes completely bioturbated in Sections 381-M0078A-72V-2, 0 $\mathrm{cm}$, to $72 \mathrm{~V}-3,24 \mathrm{~cm}$ (203.84-205.18 mbsf). The mud passes down into a more varied succession of centimeter- to decimeter-thick gray mud beds (FA5) between Sections 72V-3, 24 cm, and 73V-1, 54 cm (205.18-206.08 mbsf). The bedded mud includes shell fragments and is often moderately bioturbated with a slightly mottled appearance. The basal $\sim 30 \mathrm{~cm}$ of Subunit 1-7 returns to FA1 completely bioturbated greenish gray homogeneous mud.

\section{Subunit 1-8}

Interval: 381-M0078A-73V-1, $86 \mathrm{~cm}$, to $87 \mathrm{R}-\mathrm{CC}, 0 \mathrm{~cm}$

Depth: $206.40-236.18 \mathrm{mbsf}$ (29.78 m thick including $2.72 \mathrm{~m}$ of missing core)

The top boundary of Subunit 1-8 is sharp and characterized by a change in facies from FA1 homogeneous mud (above) to FA3 white to gray finely laminated mud (below) (Figures F4, F6). The base is marked by a change from FA2 bedded mud with organic-rich silty to fine sand layers (above) to FA4 laminated mud (below) and is accompanied by the appearance of marine microfossils (see Micropaleontology). One sand-homogeneous mud couplet occurs in Subunit 1-8.

Subunit 1-8 dominantly comprises FA5 (60\%) and FA2 (30\%) and is divided into three parts. The top part (206.4-208.44 mbsf) is an interval of dominantly FA3 white to light gray finely laminated mud. The middle part (208.44-224.34 mbsf) is mainly composed of FA5 centimeter-thick bedded greenish gray mud with subordinate millimeter- to centimeter-thick silty layers that are occasionally black and contain possible organic material. Pyrite and slight bioturbation $(\mathrm{BI}=1)$ are present in this middle part, and fine to very fine sand beds are sparsely distributed. The lower part (224.34$236.18 \mathrm{mbsf}$ ) is dominated by FA2 centimeter-thick bedded mud with frequent dark gray to black organic-rich silty to very fine sand layers with sparse pyrite.

\section{Subunit 1-9}

Interval: 381-M0078A-87R-CC, $0 \mathrm{~cm}$, to $93 \mathrm{R}-4,21 \mathrm{~cm}$

Depth: $236.18-260.70 \mathrm{mbsf}$ (24.52 m thick including $1.92 \mathrm{~m}$ of missing core)

The top of Subunit 1-9 appears sharp and is marked by a change from FA2 (above) to FA4 (below) but was picked on the basis of ma-
Figure F6. Transitional boundary over $15 \mathrm{~cm}$ from FA1 in Subunit 1-7 (marine; above) to FA3 in Subunit 1-8 (isolated/semi-isolated; below), Hole M0078A. Boundary is positioned at $86 \mathrm{~cm}$ (206.40 mbsf).

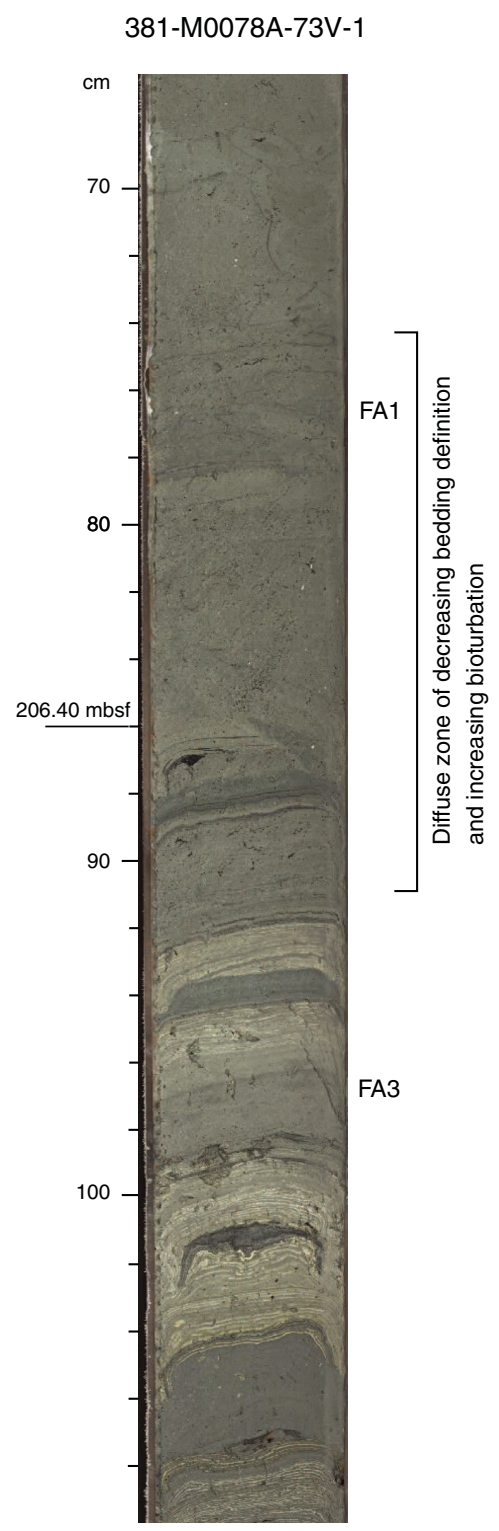

rine microfossils being present below this boundary (see Micropaleontology). The lower boundary occurs at a sharp contact between FA1 homogeneous mud (above) and FA4 (below) (Figure F4).

The upper part of Subunit 1-9 includes some intervals of FA4 but is dominated by FA3 light gray to white thin laminations and centimeter-thick homogeneous mud beds with sparse but locally intense bioturbation. FA2 greenish gray mud with dark gray to black centimeter-thick silty beds also occur. In contrast, the lower part (below Section 381-M0078A-90R-1, $110 \mathrm{~cm}$; $245.69 \mathrm{mbsf}$ ) comprises FA1 greenish gray homogeneous mud that is intensely bioturbated (BI as high as 6) with high-diversity trace fossil assemblages, including Thalassinoides, Planolites, Chondrites, and Palaeophycus. Scattered shell fragments and pyrites also occur. 


\section{Subunit 1-10}

Interval: 381-M0078A-93R-4, $21 \mathrm{~cm}$, to $101 \mathrm{R}-1,0 \mathrm{~cm}$

Depth 260.70-287.12 mbsf (26.42 m thick including $0.70 \mathrm{~m}$ of missing core)

The top of Subunit 1-10 is marked by a sharp transition from FA1 homogeneous mud (above) to FA4 (below) followed by a downhole increase in organic material content. The lower boundary is marked by a change from FA3 light gray to white laminated mud (above) to FA1 homogeneous mud (below) and a corresponding appearance of scattered shell material. The lower boundary appears sharp but may be disturbed by drilling-induced deformation (DID) (Figure F4).

Subunit 1-10 mainly consists of FA2 centimeter-scale greenish gray bedded mud alternating with thin laminated (millimeter-scale) gray to black silt and sand. Darker beds are associated with the presence of organic material and are often pyritic. This succession is interrupted by short intervals (meter scale) of FA5 interbedded centimeter-scale homogeneous and laminated greenish gray to gray mud with subordinate laminated greenish gray to gray mud. Occasionally, FA3 light gray to white submillimeter laminated mud $(<0.5$ $m$ thick) is also found in the upper and lowermost parts of Subunit $1-10$.

\section{Subunit 1-11}

Interval: 381-M0078A-101R-1, $0 \mathrm{~cm}$, to $105 \mathrm{R}-1,84 \mathrm{~cm}$

Depth: $287.12-298.84 \mathrm{mbsf}$ (11.72 m thick including $4.21 \mathrm{~m}$ of missing core)

The upper boundary of Subunit $1-11$ is marked by a change from FA3 laminated mud (above) to FA1 homogeneous mud (below). The lower boundary is marked by a change to FA4 laminated mud in Subunit 1-12 (Figure F4).

Subunit $1-11$ is dominated by FA1 homogeneous mud (91\%) with minor occurrences of FA4 and FA2 toward the base. FA1 is highly bioturbated mud with various bioclasts, abundant trace fossils (mainly identified as Chondrites, Palaeophycus, and Planolites), and pyrite. A $1.09 \mathrm{~m}$ thick FA4 and FA2 interval comprises organicrich bedded and laminated mud in various greenish gray shades (Sections 381-M0078A-104R-2, $66 \mathrm{~cm}$, to 105R-1, $33 \mathrm{~cm}$; 295.36298.33 mbsf). Below this interval, FA1 bioturbated homogeneous mud continues to the base of Subunit 1-11.

\section{Subunit 1-12}

Interval: $381-\mathrm{M} 0078 \mathrm{~A}-105 \mathrm{R}-1,84 \mathrm{~cm}$, to $111 \mathrm{R}-3,3 \mathrm{~cm}$

Depth: 298.84-322.35 mbsf (23.51 m thick including $4.23 \mathrm{~m}$ of missing core)

The top of Subunit 1-12 is marked by a change from FA1 homogeneous mud (above) to FA2 laminated mud with frequent dark gray to black mud beds (below) and the disappearance downhole of marine microfossils. Poor recovery in Core 381-M0078A-105R (19\%) prevents determination of the nature of the contact (abrupt or transitional). The lower boundary corresponds to a facies change from FA4 laminated mud (above) to FA1 homogeneous mud (below) (Figure F7). One sand-homogeneous mud couplet occurs in Subunit 1-12.

Subunit 1-12 comprises two parts, each one corresponding to one or two dominant facies associations. The upper part (Section 381-M0078A-106R-1, 0 cm, through Section 106R-3; 298.12-306.5
Figure F7. Transitional boundary from FA4 in Subunit 1-12 (isolated/semiisolated; above) to FA1 in Subunit 1-13 (marine; below), Hole M0078A. Boundary is positioned below the last laminated sediment (322.35 mbsf). Bedding disappears gradually downward over $40 \mathrm{~cm}$ in FA1, which is strongly affected by biscuiting.

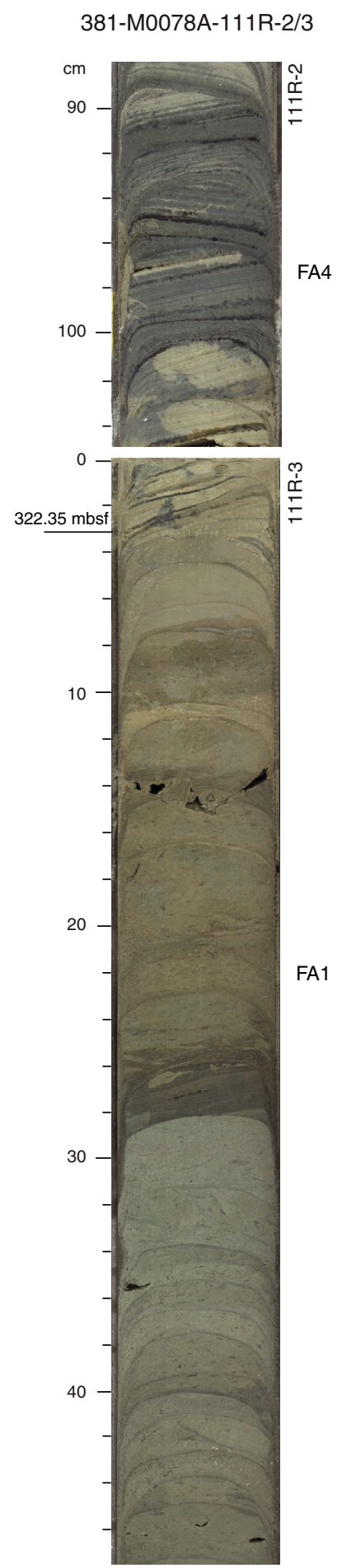

mbsf) is mainly composed of FA2 with thin organic-rich laminated mud beds, centimeter-thick organic-rich silt beds, and centimeterthick homogeneous mud beds. Below this repetitive succession of FA2 is a fining-upward sand-homogeneous mud couplet (desig- 
nated FA1 and FA10; Section 107R-1, 0-88 cm; 306.5-307.38 mbsf).

The lower part of Subunit 1-12 is characterized by further FA2 and then FA4 from Section 381-M0078A-109R-2, $0 \mathrm{~cm}$, to Section 111R-3, $28 \mathrm{~cm}$ (314.35-322.35 mbsf), with laminated mud, centimeter-scale mud beds, and sparse organic-rich laminations.

\section{Subunit 1-13}

Interval: $381-\mathrm{M} 0078 \mathrm{~A}-111 \mathrm{R}-3,3 \mathrm{~cm}$, to $114 \mathrm{R}-1,0 \mathrm{~cm}$

Depth: 322.35-334.40 mbsf (12.05 m thick including $1.6 \mathrm{~m}$ of missing core)

The top of Subunit 1-13 is marked by a gradational change from FA4 laminated mud (above) to FA1 homogeneous mud (below) (Figure F7) and a corresponding appearance of marine microfossils. The lower boundary occurs in FA3 finely laminated mud and is marked by the presence of bioturbation above the boundary, with discrete burrows descending from the drilling-disturbed boundary into otherwise unbioturbated laminated mud in Subunit 1-14 (Figure F4).

Subunit 1-13 comprises two parts with a boundary in Section 381-M0078A-113R-1, $0 \mathrm{~cm}$ (328.65 mbsf), marked by a change in the dominant facies association. The upper part is dominated by FA1 greenish gray homogeneous mud with some rare faint laminations, high levels of bioturbation, and scattered sparse small shell fragments and small disperse pyrite. This succession is interrupted by a short $(61 \mathrm{~cm})$ FA3 interval characterized by submillimeterscale cream/gray laminated mud with strong bioturbation that notably includes Teichichnus burrows. The lower part comprises gray and cream finely (submillimeter) laminated mud with a few $1-2 \mathrm{~cm}$ beds of homogeneous mud (FA3). Strong bioturbation affects this FA3 interval, including oval millimeter-scale burrows that make laminations indistinct.

\section{Subunit 1-14}

Interval: $381-\mathrm{M} 0078 \mathrm{~A}-114 \mathrm{R}-1,0 \mathrm{~cm}$, to $121 \mathrm{R}-3,38 \mathrm{~cm}$

Depth: 334.40-366.49 mbsf (32.09 m thick including $7.49 \mathrm{~m}$ of missing core)

The top of Subunit 1-14 is marked by the disappearance of bioturbation in FA3 finely laminated light mud and a transition from FA3 to FA2 downhole. The bottom of the subunit is marked by a sharp boundary from FA4 laminated mud (above) to FA5 bedded mud (below) (Figure F4) and the appearance of marine microfossils (see Micropaleontology).

Subunit 1-14 comprises three main parts with boundaries in Sections 381-M0078A-115R-1, $138 \mathrm{~cm}$, and 119R-2, $52 \mathrm{~cm}(339.28$ and $356.55 \mathrm{mbsf}$, respectively). The upper part features FA2 centimeter-thick organic-rich beds in centimeter-thick interbedded laminated mud (more common) and homogeneous mud (less common). Laminations are pale in color and very thin $(<1 \mathrm{~mm})$. The middle part consists predominantly of FA4 with occasional FA3 creamy laminated mud, with centimeter-thick homogeneous mud beds and rare organic-rich layers and very thin silt and sand beds. Sparse bioturbation and rare pyrite are present throughout. The lower part of the subunit is composed of centimeter-thick bedded and laminated mud of FA5 and FA4 with occasional millimeter- to centimeter-scale silt or very fine sand beds. Sparse to uncommon bioturbation is present throughout, with scattered rare pyrite. In the lower $1.8 \mathrm{~m}$, strongly laminated mud (FA4) lies above a sharp boundary.
Figure F8. Unit 1/2 boundary at 385.43 mbsf, Hole M0078A.

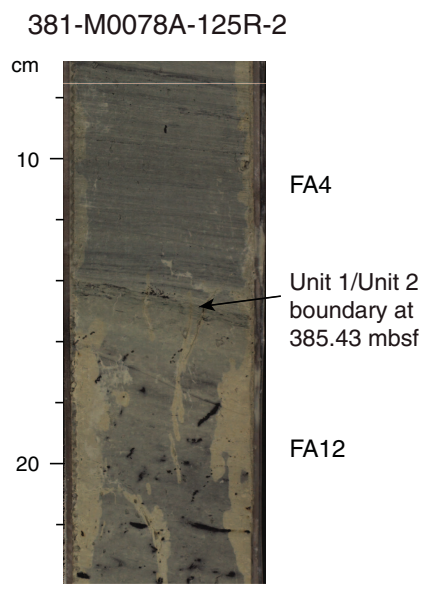

Subunit 1-15

Interval: 381-M0078A-121R-3, $38 \mathrm{~cm}$, to $122 \mathrm{R}-1,106 \mathrm{~cm}$

Depth: 366.49-369.66 mbsf (3.17 m thick including $1.79 \mathrm{~m}$ of missing core)

The top of Subunit 1-15 appears sharp and is marked by a change from FA4 laminated mud (above) to FA5 mud beds (below) and a corresponding appearance of marine microfossils. The lower boundary is marked by a change from FA1 homogeneous mud (above) to FA3 laminated mud (below) (Figure F4).

Subunit 1-15 comprises an upper $10 \mathrm{~cm}$ interval of FA5 greenish gray centimeter-scale mud beds with abundant foraminifers, shell fragments, and bioclasts that contains distinct layers of millimeterscale mud clasts. The rest of the subunit comprises FA1 greenish gray homogeneous mud that is highly to completely bioturbated with occasionally identifiable Planolites burrows and abundant shell fragments scattered throughout.

Subunit 1-16

Interval: 381-M0078A-122R-1, $106 \mathrm{~cm}$, to $125 \mathrm{R}-2,15 \mathrm{~cm}$

Depth: 369.66-385.14 mbsf (15.48 m thick including 2.94 $\mathrm{m}$ of missing core)

The top boundary of Subunit 1-16 is moderately bioturbated and characterized by a change from FA1 homogeneous mud (above) to FA3 laminated mud (below). The bottom boundary is marked by an abrupt change from FA4 laminated gray mud to FA12 light gray homogeneous mud at the top of Unit 2 (Figures F4, F8).

Subunit 1-16 is mainly composed of FA4 with minor FA3 and FA12. Close to the upper boundary, the subunit contains both white to light gray thinly laminated mud (FA3) and centimeter-thick bedded gray mud (FA5) with pyrite and shell fragments. Directly below is a $2 \mathrm{~m}$ interval of FA12 highly bioturbated light gray to beige mud that is rich in pyrite. The bottommost $12.9 \mathrm{~m}$ is mainly composed of FA4 millimeter-scale laminated gray mud with some centimeterthick beds and one interval with dominantly centimeter-thick bedded mud (FA5; 373.6-378.6 mbsf). Pyrite, millimeter-thick dark, probably organic-rich layers, and broken shell fragments are common, whereas bioturbation is sparse. Several intervals with centimeter-thick slumps or debris flows and centimeter-scale silty to sandy layers that fine upward also occur. 


\section{Unit 2}

Interval: $381-\mathrm{M} 0078 \mathrm{~A}-125 \mathrm{R}-2,15 \mathrm{~cm}$, to $176 \mathrm{R}-3,8 \mathrm{~cm}$ (base of hole)

Depth: 385.14-610.43 mbsf (225.29 m thick including $43.19 \mathrm{~m}$ of missing core)

Age: Pleistocene

The top of Unit 2 is a sharp boundary marked by an abrupt change from FA4 laminated greenish gray mud (above) to FA12 light gray homogeneous mud (below) (Figures F4, F8). The uppermost $15 \mathrm{~cm}$ of Unit 2 is characterized by abundant millimeter- to centimeter-scale pyritized burrows (mainly subhorizontal) (Figure F8). Unit 2 is composed almost entirely of FA12 (99\%), with rare FA4, FA5, and FA11 occurrences. FA12 consists of light gray homogeneous mud with a high bioturbation intensity $(\mathrm{BI}=4-6)$. Ichnological diversity is low to moderate, mainly including Planolites, Chondrites, and Teichichnus, but trace fossils are commonly undetermined because of the intense bioturbation. Sporadic framboidal and linear occurrences (infills of burrows?) of pyrite are common. A minor FA12 subfacies association comprises darker gray mud with faint bedding and black laminations associated with higher organic matter content and reduced bioturbation intensity $(\mathrm{BI}=\sim 4)$. The bedded and laminated mud of FA4 and FA5 occurs mainly in the uppermost $20 \mathrm{~m}$ of Unit 2, forming roughly $50-70 \mathrm{~cm}$ thick packages (391.10-391.59, 396.75-397.48, and 405.10-405.58 mbsf). The whole of Unit 2 is strongly affected by DID (biscuiting) (see Structural geology).

\section{Interpretation of Site M0078}

The Site M0078 lithostratigraphy is dominated by mud facies with minor sand and silt, indicating a distal subaqueous environment with low clastic input. Detrital calcite predominates throughout but with somewhat decreasing importance upward through the succession. Quartz, feldspar, and phyllosilicates represent subordinate minerals (in order of importance). Biogenic material is common, particularly in the marine subunits.

The most significant lithostratigraphic boundary (between Units 1 and 2) is marked by an abrupt uphole change from the highly monotonous FA12 succession in Unit 2 to a cyclical pattern of facies association changes in the overlying Unit 1 . The 16 subunits in Unit 1 fall into two alternating types: those composed predominantly of the homogeneous green gray mud of FA1 and FA6 (odd-numbered subunits, Figure F4) and those composed predominantly of laminated and bedded mud of various facies associations, in particular FA5 (even-numbered subunits, Figure F4). These alternating types of subunits in Unit 1 are provisionally identified as representing marine and isolated/semi-isolated environments for oddand even-numbered subunits, respectively, with good correlation with micropaleontology results (see Micropaleontology).

Marine subunits in Unit 1 (odd numbers) are moderately to highly bioturbated and dominated by homogeneous to poorly bedded greenish gray mud with scattered shell debris. Isolated/semiisolated subunits (even numbers) are dominated by laminated to thinly bedded gray and greenish gray mud, some with black, organic-rich laminations and beds but with no, or only sparse, bioturbation or shell debris. In both the marine and isolated/semi-isolated subunits, sedimentary processes were dominated by deposition from fine-grained, low-concentration turbidity currents and hemipelagic suspension fallout. Sand-homogeneous mud couplets represent significant turbidite input, whereas centimeter- to millimeter-thick graded silt and sand represent a background of regular low-volume distal turbidite input. Compared with Site M0079, slumped units, mud-supported conglomerates, and sandhomogeneous mud couplets are relatively rare and thin in Holes M0078A and M0078B, suggesting a more stable environment or a location that was relatively well protected from incoming sediment derived from slope failure or sediment gravity flows sourced from the major catchments surrounding the rift, which is consistent with the position of Site M0078 on an intrabasinal horst (see Figure F2).

Unit 2 is dominated by monotonous FA12 light gray to buff homogeneous to weakly laminated highly bioturbated mud. The boundary with overlying Unit 1 is sharp, and the uppermost $15 \mathrm{~cm}$ of Unit 2 is characterized by abundant millimeter- to centimeterscale subhorizontal pyritized burrows. These characteristics suggest a possible unconformity between Units 1 and 2. No compositional change was observed across this boundary in XRD or smear slide data (Figure F5).

\section{Structural geology}

DID and tectonic deformation were systematically recorded in Holes M0078A and M0078B. The north-south seismic reflection profile shows the tectonic location of Site M0078 on an uplifted horst block (Figure F2) with beds that are progressively tilted southward (as much as $13^{\circ}$ ) in the footwall of a major north-dipping normal fault. Because Site M0078 is located between two prominent faults, we did not expect to encounter any major structures in the borehole, and observations in the core confirm there are none.

\section{Observed tectonic structures}

Bedding attitude in the core is generally horizontal to subhorizontal through the core despite the gradual increase in dip of seismic reflection horizons around Site M0078. Locally, bedding can be tilted through full core sections (i.e., natural tilting rather than drilling induced) with apparent bedding dips as high as $24^{\circ}$ (Section 381-M0078A-126R-3; 391.59-393.10 mbsf). These local dips are higher than those measured from the north-south seismic reflection profile, which could be due to the lower resolution of the individual seismic reflectors or the seismic profile not displaying the true dip.

Small-scale natural faulting was observed sporadically throughout the core, including frequent normal faults and rare suspected strike-slip faults (Figure F9). These natural faults were distinguished from DID by their planar geometries and the lack of influence by proximity to either the core liner, core axis (i.e., curving inward to become parallel to the core axis or curving into the core liner; conjugate fractures that are symmetrical on the core central axis), or other forms of DID. The shallowest observed natural fault is in Section 381-M0078A-9H-1 (19.21-20.52 mbsf), and faulting intensity per section (when observed) generally increases with depth (Figure F10A). Concentrated faulting in discrete intervals was also observed, such as in Core 113R (329.4-334.4 mbsf), where 20 small normal faults were recorded (Figures F10A, F11). In particular, abundant faulting was consistently recorded in Sections 113R-1 through 139R-2 (329.4-447.33 mbsf) (Figure F10A). Below this interval, no faulting was observed until Section 164R-1 (564.01 mbsf), where the deepest faults were observed. The apparent absence of small faults from Section 139R-2 through Section 164R-1 may be related to high-intensity rotary drilling-induced biscuiting throughout the interval (see below).

The vast majority of natural faults observed at Site M0078 have apparent normal displacements ranging from 1 to $350 \mathrm{~mm}$. A total 
Figure F9. Small tectonic faults observed in Hole M0078A cores (top: interpreted, bottom: uninterpreted). Blue and yellow = bedding, red $=$ fault traces. A. Normal fault (113R-1). B. Possible strike-slip or oblique-slip fault showing variable slip sense along its length (118R-3).

\section{A}
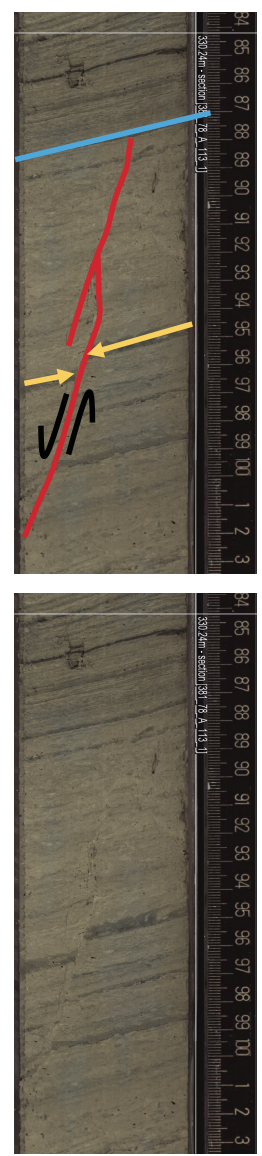

B
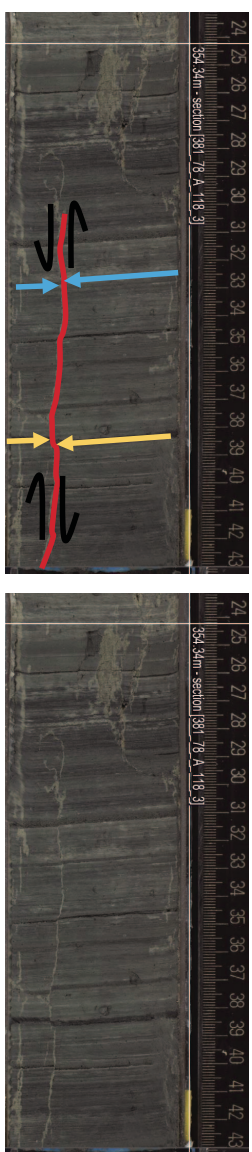

of 30 normal faults were sampled for orientation analysis. These faults appear to form conjugate sets throughout the core, as illustrated by the stereographic projection of several normal faults in the core reference frame in Core 381-M0078A-113R (329.4-334.4 mbsf) (Figures F10B, F11). The sampled normal faults show true dips ranging from $42^{\circ}$ to $82^{\circ}$ but with a clear modal average of $60^{\circ}-$ $70^{\circ}$ and a mean fault dip of $66^{\circ}$ (Figure F10C). The abundance and geometry of small normal faults are in agreement with the overall extensional nature of the rift deformation. Because cores were not oriented, the fault orientation measurements were not corrected to geographic north; this correction (using paleomagnetic data) will only be possible where the core has not been affected by DID (biscuiting).

\section{Observed drilling-induced deformation}

A range of drilling-induced structures was observed at Site M0078. The most common were biscuiting (Figure F12C), arching bedding, tilted panels, lensing, sediment smearing/flow along the core liner, voids, and open fractures. Other less frequently observed structures are listed in Table T1 in the Expedition 381 methods chapter (McNeill et al., 2019b). In general, DID intensity increases downhole, as in Hole M0078A (Figure F12A), and is particularly intense in rotary cores.
Figure F10. Preliminary analyses of natural faults, Hole M0078A. A. Fracture intensity (number of fractures per meter; log scale). B. Lower hemisphere equal-area stereographic projection showing 18 small normal fault orientations in the core reference frame (see text for details). The faults describe a clear conjugate normal fault system. C. Fault dip frequency measured in the core reference frame in Hole M0078A cores showing distribution around a mean dip of $66^{\circ}$.

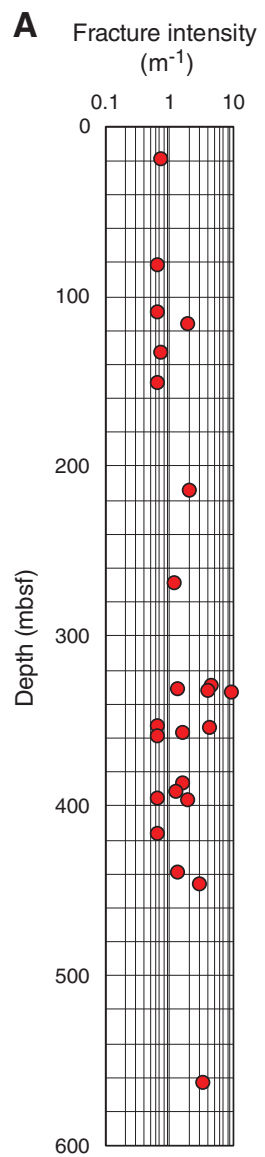

B

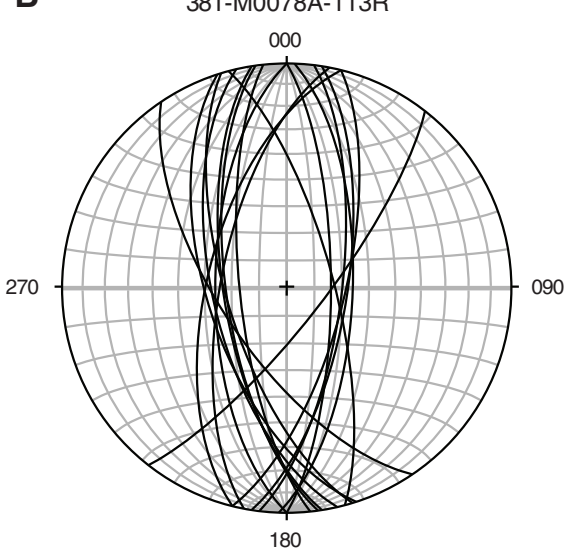

C

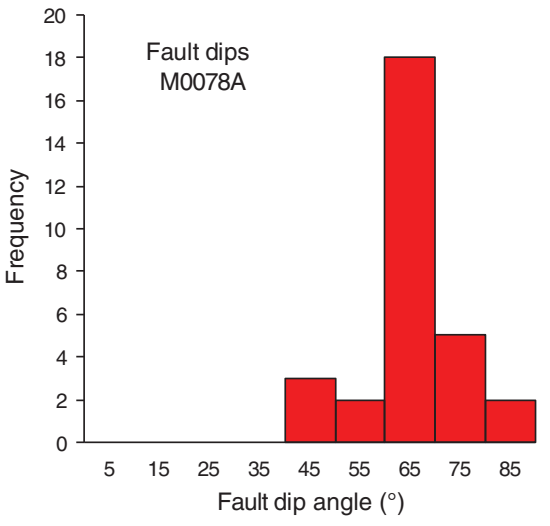

The recording of DID through the upper part of Hole M0078A was patchy because our initial methodology was not robust. However, DID was correctly recorded in adjacent Hole M0078B (Figure F12B). Soupy texture was often found in the uppermost part of the hole through Core 381-M0078A-12H (29.94 mbsf). Hydraulic piston coring was used throughout Core $28 \mathrm{H}$ (75.19 mbsf), which generated sporadic, slight-moderate DID intensity that was mainly expressed by arching bedding and disrupted/mingled beds with rare axial flow and open fractures. For Cores 29P through 70P (75.1999.14 mbsf), hydraulic push coring was used, producing sporadic, slight-moderate DID intensity characterized by arching bedding, lensing, and disrupted/mingled beds with rare voids and open fractures. Hydraulic percussive coring was used for a short interval from Core $71 \mathrm{~V}$ through Core $83 \mathrm{~V}$ (199.14-224.34 mbsf) and was associated with moderate-high DID intensity predominantly expressed by arching bedding and lenses.

Core 381-M0078A-84R (224.34 mbsf) marks the onset of rotary coring, which was used to the bottom of the hole. Rotary coring is associated with a marked and consistent increase in DID intensity (moderate-high). Deformation is dominated by biscuiting and sediment (and drilling fluid) inflow between biscuits. Notably, biscuit- 
Figure F11. Several small conjugate normal faults from Core 381-M0078A$113 \mathrm{R}$ where the highest fracture intensity values were recorded (top: interpreted, bottom: uninterpreted). Blue and yellow $=$ bedding, red $=$ fault traces, orange $=$ drilling-induced void opening and new fault.
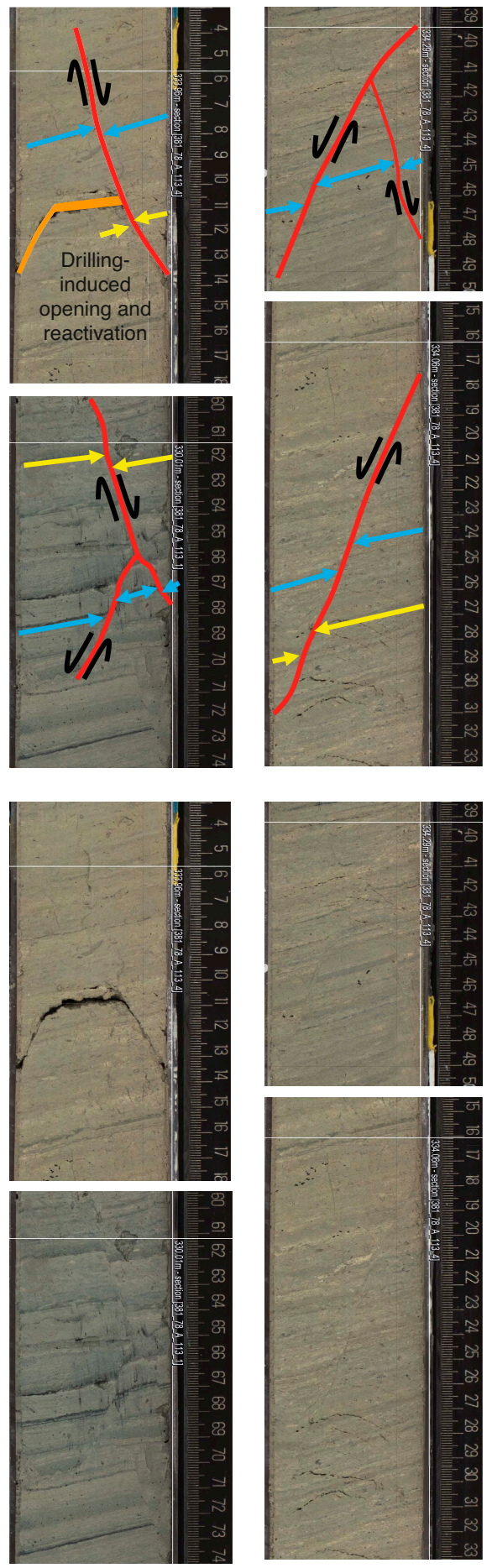

Figure F12. DID intensity (0-4). Coring method is represented in shades of gray from piston $(\mathrm{H})$ to push $(\mathrm{P})$ to percussive $(\mathrm{V})$ to rotary $(\mathrm{R})$. White $=$ no core recovery. A. Hole M0078A clearly showing an abrupt increase in DID intensity once the $V$ and $R$ methods were used. B. Hole M0078B. C, D. Examples of biscuiting, the dominant form of DID (C: 381-M0078A-144R-1; D: 84R-2).

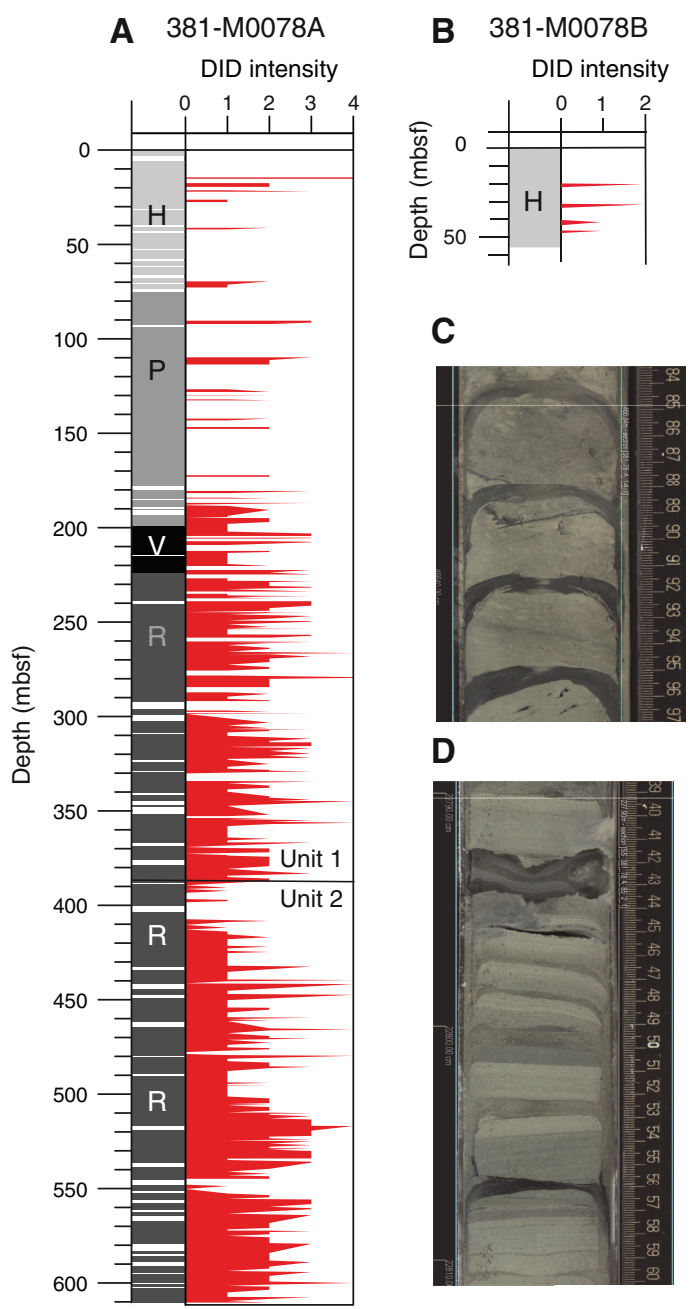

ing is absent in Sections 125R-3 through 140R-1 (386.49-449.49 mbsf), coinciding with the upper part of lithostratigraphic Unit 2, but biscuiting returns again below this interval to the base of the hole. A wide variety of other DID types occur during rotary coring, in particular arching bedding, sediment flow along the core liner, lensing, tilted panels, and open fractures.

Because mud is the dominant lithology throughout the site, the main variations in drilling deformation are likely to be predominantly related to the coring method rather than lithology. A possible relation to style and intensity of drilling deformation should also be found with progressive compaction, lithification, and hence increasing strength with depth. Thus, comparison with physical properties results is also recommended; however, this comparison was not undertaken as part of the Expedition 381 "shipboard" analyses. 


\section{Micropaleontology}

For Expedition 381, micropaleontological analysis included calcareous nannofossils, marine and nonmarine diatoms, planktonic and benthic foraminifers, and palynomorphs (including terrestrial and aquatic pollen grains, fern spores, dinoflagellate cysts, green algae coenobia and spores, fungal remains, foraminifer test linings, and microscopic charred particles). Calcareous nannofossils, marine and nonmarine diatoms, and planktonic and benthic foraminifers were prepared from core catcher samples offshore and examined at approximately $5 \mathrm{~m}$ intervals to a total depth of 610.38 mbsf. This combined examination of microfossil groups revealed alternating marine, mixed (marine with nonmarine), nonmarine, and undetermined (e.g., barren) microfossil assemblages resulting from complex environmental and depositional settings through time. See Micropaleontology in the Expedition 381 methods chapter (McNeill et al., 2019b) for a complete definition of these categories.

Shipboard micropaleontology work was divided among micropaleontology specialists, providing focused examinations of each microfossil group with the goal of understanding marine and terrestrial ecology and depositional environments and defining the boundaries across which the depositional environment shifted by integrating micropaleontological constraints with those from sedimentological information and physical properties. Another goal of shipboard micropaleontology is to obtain preliminary age information.

Hole M0078A is divided into two major lithostratigraphic units -1 (equivalent to seismic Unit 2) and 2 (equivalent to seismic Unit 1)-defined by a unit boundary and possible unconformity at approximately 385.14 mbsf (Section 125R-2). Unit 1 (0-385.14 mbsf) is further divided into 16 subunits by integration of lithologic and physical properties characteristics and observed microfossil assemblages. Fully marine microfossil assemblages occur in 8 of these 16 subunits. Unit 2 is not divided into subunits at this time because of the homogeneity of the lithology and the complexity revealed by initial micropaleontological investigations.

\section{Calcareous nannofossils}

Calcareous nannofossils were observed in almost every sample from lithostratigraphic Unit 1 in Hole M0078A, regardless of depositional environment. However, calcareous nannofossil assemblages observed in mixed microfossil assemblages have significantly lower total abundance and diversity than assemblages through the intervals that represent a fully marine environment (Tables T4, T5).

With the exception of Subunit 1-1, Gephyrocapsa "small" $(<4$ $\mu \mathrm{m})$ is the most dominant species throughout Unit 1 . Other observed species tend to be opportunistic types that display tolerance for elevated nutrients, terrigenous input, and adaptations to stressful environments (Dimiza et al., 2014, 2016; Wade and Bown, 2006; Perch-Nielsen, 1985).

The Subunit 1-1 marine interval (0-20.78 mbsf) is dominated by Emiliania huxleyi, which is the most dominant nannofossil in the modern ocean (Perch-Nielsen, 1985) and whose first appearance datum (FAD) marks 0.29 Ma (Backman et al., 2012). The last downhole occurrence (LDO) of E. huxleyi is noted at the bottom of Subunit 1-3 in Section 381-M0078A-41P-3 (121.82 mbsf). However, this occurrence is likely not the true FAD because $E$. huxleyi evolved during glacial marine isotope Stage (MIS) 8, a time when the Gulf of Corinth was presumably disconnected from the Mediterranean Sea. Consequently, the base of E. huxleyi should not be used as a geologic age marker here.
Table T4. Qualitative data for calcareous nannofossils and marine and nonmarine diatoms, Hole M0078A. Download table in CSV format.

Table T5. Qualitative data for calcareous nannofossils and marine and nonmarine diatoms, Hole M0078B. Download table in CSV format.

From Subunit 1-1 to Subunit 1-3, a conspicuous shift in dominance from E. huxleyi to Gephyrocapsa "small" occurs. The timing of this crossover in dominance was documented and discussed by Thierstein et al. (1977), Raffi et al. (2006), and Anthonissen and Ogg (2012), among others. The timing of this crossover appears to be time-transgressive depending on latitude and is not well calibrated (Thierstein et al., 1977), so one should proceed with caution when applying this datum. Anthonissen and Ogg (2012) documented this crossover at $0.07 \mathrm{Ma}$ in the Mediterranean Sea, which corresponds to early MIS 4 (Lisiecki and Raymo, 2005). If this datum is applied to Hole M0078A in the Gulf of Corinth, then MIS 4 is represented by Subunit 1-2. Unfortunately, this crossover cannot be better characterized here because of the isolation/semi-isolation of the Gulf of Corinth during this period.

Although reworked nannofossils were observed in nearly every sample, a notably higher amount of reworking was observed in the Subunit 1-5 marine interval (180.14-188.15 mbsf). Calpionellids, a small group of late Tithonian to early Valanginian planktonic protozoans (Remane, 1985), were observed in this interval, along with an increased volume of Paleogene and Cretaceous nannofossils. The in situ nannofossil assemblage is composed of a significantly higher number of Helicosphaera carteri, a species commonly found in warm, nutrient-enriched waters and considered tolerant of lower salinity waters diluted by terrestrial runoff (Dimiza et al., 2014). The characteristics of this microfossil assemblage were not observed in any other marine subunit at this site.

The next oldest calcareous nannofossil marker, Pseudoemiliania lacunosa, whose last appearance datum (LAD) marks $0.43 \mathrm{Ma}$, was observed in Sample 381-M0078A-105R-1, $60 \mathrm{~cm}$ (298.6 mbsf), which was taken during the Onshore Science Party (OSP). This marker species was not observed in core catcher samples taken offshore immediately around this sample, nor was it observed in any of the deeper marine core catcher or core samples collected from Hole M0078A. In addition to being observed in only one sample, this occurrence is likely not the true LAD because the extinction of $P$. lacunosa occurs in glacial MIS 12, a time when the Gulf of Corinth was presumably disconnected from the Mediterranean Sea. Therefore, biostratigraphic application of P. lacunosa should be conservative.

If the observation of P. lacunosa is in fact the LAD, and if the stratigraphy is considered to be continuous, then an average sedimentation accumulation rate of $0.7 \mathrm{~m} / \mathrm{ky}$ is implied. This estimate does not take into account compaction or attempt to remove gravity flow deposits. However, if this sedimentation rate is accurate, then the lowest occurrence of E. huxleyi should be at approximately 200 mbsf (Core $71 \mathrm{~V}$ ), further supporting the hypothesis that the LDO of E. huxleyi in Hole M0078A does not represent the FAD of the species.

Unit 2 is almost completely devoid of calcareous nannofossils, and most specimens that were observed are interpreted to be reworked. The few observed specimens that were not obviously reworked were not observed in abundances high enough to determine whether they were in place or the result of contamination. 
Calcareous nannofossils in Hole M0078B (Table T5) were observed in Subunit 1-1 from 0 to $20.56 \mathrm{mbsf}$, which is stratigraphically equivalent to Subunit 1-1 in Hole M0078A.

\section{Marine diatoms}

Marine diatoms were observed in intervals with fully marine microfossil assemblages, except for Subunits 1-1 and 1-11 in Hole M0078A (Table T4). Marine diatoms were not observed in Hole M0078B. Marine diatoms were also observed in low abundances in Subunits 1-2 and 1-4, which were characterized as mixed microfossil assemblages by shipboard analyses.

The most abundant and diverse marine diatom assemblage was observed in Subunit 1-15 (Cores 381-M0078A-121R and 122R; 366.6-369.4 mbsf). This assemblage also includes other siliceous microfossils, such as radiolarians and silicoflagellates, and abundant calcareous nannofossils. A similar assemblage was observed in Hole M0079A in Subunit 1-16, just above the Unit 1/2 boundary (see Mi-

Table T6. Nonmarine diatom counts, Hole M0078A. Download table in CSV format. cropaleontology in the Site M0079 chapter [McNeill et al., 2019c]). Further quantitative analysis is required to determine whether these assemblages are correlative.

\section{Nonmarine diatoms}

Offshore, nonmarine diatoms were primarily examined in smear slides made from core catcher samples. Further examination of the nonmarine diatoms during the OSP sought to improve species identification (Tables T4, T6) and increase the understanding of ecology (Table T7). Onshore diatom analyses focused on selected intervals, aiming to identify the species and to describe the diatom assemblages according to the species' environmental preferences. Analyses were conducted only on Hole M0078A samples; no samples from Hole M0078B were examined.

Diatom assemblage analyses were carried out on 45 samples from Cores 381-M0078A-10H through 158R (23.74-534.65 mbsf), targeting sections characterized as having mixed and nonmarine microfossil assemblages during the preliminary analyses conducted offshore. Diatoms are preserved throughout these sections at variable stages of dissolution, and 38 taxa, including morphological va-

Table T7. Most common diatom taxa observed at Site M0078 and their environmental preferences. NA = not applicable/not known. Diatom preferences are according to the information available at http://www.algaebase.org, http://www.marinespecies.org, and https://westerndiatoms.colorado.edu and from Krammer and Lange-Bertalot (1991), Van Dam et al. (1994), Houk et al. (2010), Reed et al. (2010), and Cvetkoska et al. (2012, 2016). Download table in CSV format.

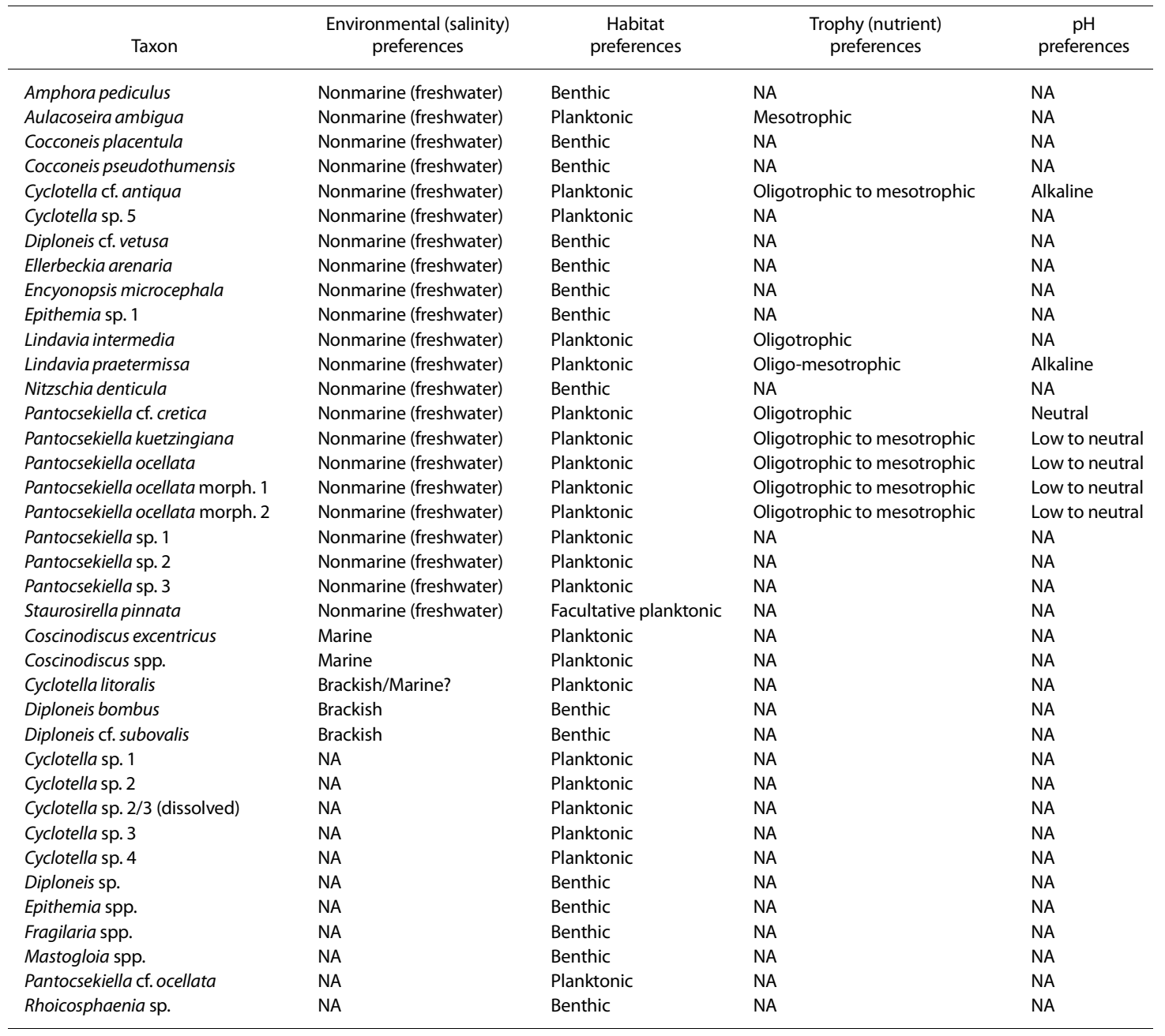


Figure F13. Preliminary stratigraphic diagram of most common nonmarine diatom taxa observed in Hole M0078A. Taxa abundances are shown as counts and total counts per sample. Relative proportions of taxa are grouped according to salinity, habitat, and nutrient and alkalinity preferences. Blue $=$ marine microfossil assemblages, green $=$ mixed microfossil assemblages, gray $=$ undetermined microfossil assemblages, purple $=$ nonmarine microfossil assemblages .

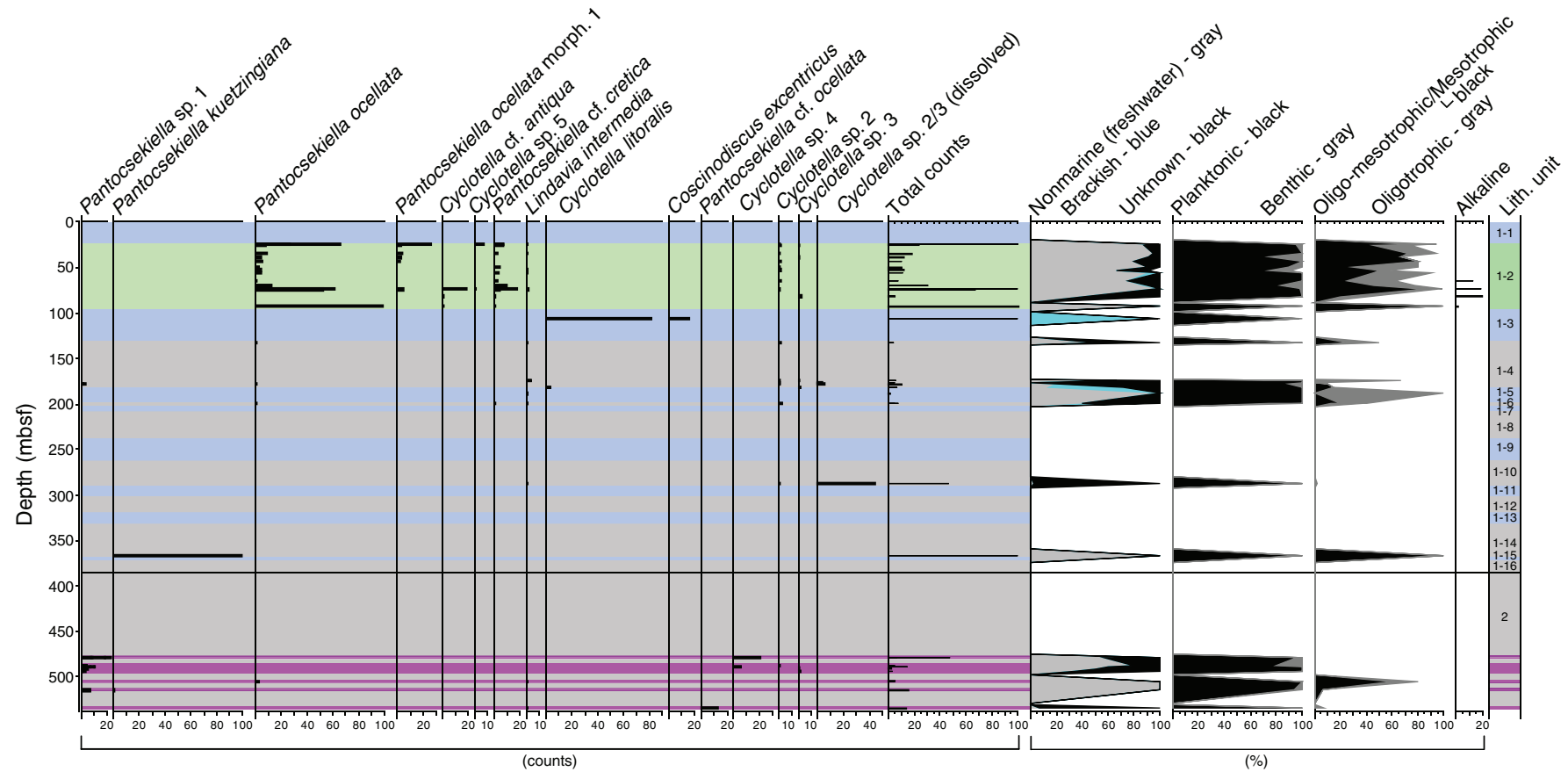

rieties, were identified. The preliminary diatom stratigraphy of the targeted sections is presented in Figure F13, and the data are annotated in Table T6.

\section{Unit 1 (Cores 381-M0078A-1P through 125R; 0-385.14 mbsf)}

In the Unit 1 isolated/semi-isolated intervals, nonmarine diatoms are common to abundant with good to excellent preservation. Surprisingly, nonmarine diatoms in the isolated/semi-isolated intervals were typically observed co-occurring with low abundances of marine microfossils. When this combination was recognized and the fossils were interpreted to be in situ, the sample is described as having a mixed microfossil assemblage (see Micropaleontology in the Expedition 381 methods chapter [McNeill et al., 2019b]). Nonmarine diatoms observed in the Unit 1 isolated/semi-isolated intervals are not diverse and are dominated by species from the planktonic Pantocsekiella ocellata complex, including several morphotypes (Tables T4, T5, T6).

In the marine intervals, nonmarine diatoms were rarely observed. When nonmarine diatoms were observed in the marine intervals, their abundances are low and preservation poor, indicating that they are not in situ.

A total of 126 samples were analyzed offshore and an additional 29 samples were analyzed onshore from Unit 1 . The mixed microfossil assemblage in Cores 381-M0078A-10H through 33P (Subunit $1-2 ; 23.74-92.22 \mathrm{mbsf}$ ) is characterized by planktonic assemblages with higher abundances and better preservation than was observed in mixed assemblages from deeper sections of Unit 1 . The nonmarine planktonic taxa belonging to the $P$. ocellata complex dominate throughout these cores, with the highest peaks ( $>50$ counts) in Cores 10H (24.09 mbsf), 26H-28H (69.12-73.09 mbsf), and 33P (92.22 mbsf) (Figure F13). P. ocellata is a widespread diatom species complex usually reported from the epilimnetic zone of the nonmarine ecosystems. Planktonic Pantocsekiella cf. cretica, Lindavia intermedia, and Cyclotella cf. antiqua simultaneously occur with the $P$. ocellata complex in these assemblages but in much lower abundances. Benthic nonmarine Cocconeis placentula, Encyonopsis microcephala, Staurosirella pinnata, and brackish taxa such as Diploneis cf. subovalis were observed only sporadically in these assemblages. A common planktonic taxon with unknown salinity and nutrient preferences in these samples is Cyclotella sp. 2.

The diatom assemblages in Cores 381-M0078A-44P through 100R (172.3-287.17 mbsf) are mostly characterized by low diatom counts $(<20$ valves per traverse) and moderate preservation. The nonmarine planktonic diatoms in these cores have low abundances, represented by Aulacoseira ambigua, P. ocellata, Pantocsekiella sp. 1 , and $L$. intermedia, occurring at $<5$ valves per sample. Taxa with unknown salinity preferences, such as Cyclotella sp. 2, Cyclotella sp. 3, Cyclotella sp. 2/3 (dissolved), and Cyclotella sp. 4, are present in higher abundances. A unique assemblage in Core 100R (287.17 mbsf) is characterized by $\sim 50$ valves per traverse and a high abundance of dissolved valves, probably belonging to Cyclotella sp. 2 and Cyclotella sp. 3. High abundances of marine planktonic Cyclotella litoralis and Coscinodiscus spp. and benthic Diploneis bombus are present in Cores 62P (181.57 mbsf) and 71V (199.16 mbsf). The lowermost sample analyzed from this unit is in Core 121R $(366.42$ mbsf). It includes an assemblage characterized by a "bloom" of the nonmarine planktonic diatom Pantocsekiella kuetzingiana and marks the boundary between the marine microfossil assemblages that occur in the lowermost part of Unit 1 and the undetermined assemblages in Sections 113R-4 through 121R-3 (334.41-366.24 mbsf).

\section{Unit 2 (Cores 381-M0078A-125R through 176R; 385.14-610.38 mbsf)}

In Unit 2, nonmarine diatoms were observed in "unmixed" assemblages that are preliminarily classified here as freshwater assemblages (475.7-536.31 mbsf). Onshore, 16 additional samples were examined from Cores 381-M0078A-145R through 158R (474.13- 
534.65 mbsf). Planktonic diatoms from the genera Cyclotella, Pantocsekiella, and Lindavia dominate the assemblages observed in Unit 2. Diatoms are present in Samples 146R-3, $40 \mathrm{~cm}$, to 149R-3, 67 cm (478.89-494.16 mbsf); 151R-3, $77 \mathrm{~cm}$, to 153R-CC, $13 \mathrm{~cm}$ (504.78-514.66 mbsf); and 158R-1, $85 \mathrm{~cm}$ (534.65 mbsf). The total diatom counts are low ( $<20$ valves per traverse), except for Section 146R-3 (479.02 mbsf), where a total of 48 valves were counted. The assemblages throughout these cores are dominated by planktonic Cyclotella sp. 2, Cyclotella sp. 3, and Cyclotella sp. 4, P. ocellata, Pantocsekiella cf. ocellata, Pantocsekiella sp. 1, Pantocsekiella sp. 2, and Pantocsekiella sp. 3. Freshwater benthic taxa such as Amphora pediculus, C. placentula, and Cocconeis pseudothumensis occur only sporadically.

In addition, the samples from Cores $145 \mathrm{R}$ (474.13, 474.44, and $475.12 \mathrm{mbsf}$ ), 150R (498.03 and $498.25 \mathrm{mbsf}$ ), 156R (528.55 mbsf), and $157 \mathrm{R}$ ( $530.43 \mathrm{mbsf}$ ) are barren of diatoms, thus indicating very poor diatom preservation and/or low productivity.

Planktonic taxa from the genera Cyclotella and Pantocsekiella are characterized by the high morphological variability of their external and internal valve features. Because of the complexity of these variations, additional scanning electron microscope analyses during postexpedition research are required to reveal the nature of the variability and improve species identification.

\section{Foraminifers}

\section{Hole M0078A}

A total of 168 samples were examined for planktonic and benthic foraminifers; 118 core catcher samples were taken offshore, and 50 additional core samples were taken from split-core sections during the OSP (Table T8).

Foraminifer specimens were observed in high abundances only in specific intervals in lithostratigraphic Unit 1 and always with variations in their composition. In Unit 1 , sedimentary intervals with abundant foraminiferal fauna alternate with intervals where foraminifers are almost absent. These changes in the foraminifer records are almost in phase with Subunits 1-1 through 1-16. Eight of these subunits include intervals with relatively high abundances of benthic and/or planktonic foraminifer species, suggesting the prevalence of marine conditions:

- 0-20.31 mbsf, which corresponds to Subunit 1-1;

- 96.42-121.81 mbsf, which corresponds to Subunit 1-3;

- 180.16-186.16 mbsf, which corresponds to Subunit 1-5;

- 202.26-205.62 mbsf, which corresponds to the central part of Subunit 1-7;

- 245.16-260.56 mbsf, which corresponds to the central and lower parts of Subunit 1-9;

- 287.5-298.6 mbsf, which corresponds to the central part of Subunit 1-11;

- 322.64-329.04 mbsf, which corresponds to the central part of Subunit 1-13 and includes a short interval where foraminifers appear in low abundance (Sample 381-M0078A-112R-3, 75.5$77.5 \mathrm{~cm} ; 328.155 \mathrm{mbsf})$; and

- 366.6-369.5 mbsf, which corresponds to Subunit 1-15.

In all the other intervals in Unit 1, which correspond to the remaining subunits $(1-2,1-4,1-6,1-8,1-10,1-12,1-14$, and 1-16), foraminifers appear in lower abundances or they are absent (Table T8). The low foraminiferal content in these intervals may suggest weakened marine conditions or nonmarine conditions. Two samples do not follow this trend: Sample 381-M0078A-44P-3CC, 3-4 cm (132.6 mbsf), from Subunit 1-3 and Sample 122R-5CC, 6-7 cm
Table T8. Benthic and planktonic foraminifer counts, Hole M0078A. Download table in CSV format.

Table T9. Relative abundances of benthic foraminifer species, Hole M0078A. Download table in CSV format.

Table T10. Relative abundances of planktonic foraminifer species, Hole M0078A. Download table in CSV format.

(373.7 mbsf), from Subunit 1-15, where foraminifers increase in abundance.

In the intervals with abundant foraminiferal fauna, benthic foraminifer associations are usually highly diversified and are mainly composed of shallow and deep infaunal species typical of normal salinity under moderate to high organic carbon inputs to the seafloor, such as species of genus Bulimina and Brizalina, as well as Melonis barleeanus and Cassidulina carinata (Goineau et al., 2011, and references therein) (Table T9). Samples containing moderate to high abundances of small species could imply input of labile organic material to the seafloor (i.e., exclusive of the $63-125 \mu \mathrm{m}$ fraction), such as Nonionella cf. iridea, Eilohedra vitrea, and Cassidulina obtusa (Duchemin et al., 2007). In the intervals with abundant foraminiferal fauna, benthic foraminifer abundance is always higher than that of planktonic foraminifers, except for the intervals corresponding to Subunits 1-11 and 1-15, where planktonic foraminifer abundance is higher than that of benthic foraminifers (Table T10).

The planktonic foraminifer associations usually present low diversities, and when they appear in high abundance, they are usually represented by species that are interpreted to be indicative of relatively cool waters in the surficial or deeper water layers (Turborotalita quinqueloba, Neogloboquadrina pachyderma, Neogloboquadrina dutertrei, Globorotalia inflata, and Globigerinita glutinata) (Rohling et al., 1993; Pujol and Vergnaud Grazzini, 1995; Capotondi et al., 2016). The participation of the warm water species (Globigerinella spp., Globigerinoides ruber, Globigerinoides trilobus, Globoturborotalita spp., Hastigerina pelagica, and Orbulina universa) (Rohling et al., 1993; Pujol and Vergnaud Grazzini, 1995) in the planktonic associations is low (Table T10). Warm water species were obtained in the intervals corresponding to Subunits 1-9 and 1-11. In the samples with abundant planktonic foraminifers, the dominant planktonic species were often $T$. quinqueloba or N. pachyderma together with N. dutertrei or G. inflata. The dominance of planktonic species $T$. quinqueloba in some parts of Subunits 1-3, 1-5, 1-9, 1-11, and 1-15 could suggest the prevalence of surficial water with relatively low salinity and low temperature and/or enhanced fertility (Rohling et al., 1993; Pujol and Vergnaud Grazzini, 1995) in these intervals. Samples where the dominant planktonic species were $N$. pachyderma together with $N$. dutertrei, which were obtained in some parts of Subunits 1-3, 1-9, 111 , and 1-15, could suggest the development of a deep chlorophyll maximum layer (Rohling and Gieskes, 1989; Rohling et al., 1993) in these intervals. The dominance of G. inflata obtained in one sample from Subunit 1-15 may suggest the development of a cool and deep mixed water layer (Rohling et al., 1993; Pujol and Vergnaud Grazzini, 1995) in this interval.

Benthic and planktonic foraminifers are absent throughout Samples 381-M0078A-124R-5, 0-1 cm, to 176R-1, 3-4 cm (all of which correspond to Unit 2), except for trace amounts of poorly preserved benthic foraminifers found in Sample 167R-2, 0-1 cm (575.03 mbsf) (Table T8). 


\section{Hole M0078B}

Benthic foraminifers are generally abundant in Cores 381M0078B-1P through 8P (1.3-20.55 mbsf), which correspond to Subunit 1-1, except for two samples containing low foraminiferal abundance: 3P-2CC, $14-15 \mathrm{~cm}$ (6.15 mbsf), and 7P-3CC, $6-7 \mathrm{~cm}$ (19.06 mbsf). Only trace abundances of planktonic foraminifers were observed in this interval (Table T11). The benthic foraminiferal species that characterize this interval are Bolivina spathulata, C. carinata, Bulimina marginata, Hyalinea balthica, M. barleeanus, Sigmoilina distorta, $N$. cf. iridea, and C. obtusa.

Benthic and planktonic foraminifers are in trace abundance in Samples 381-M0078B-8P-4CC, 0-1 cm, to 15P-4CC, $14-15 \mathrm{~cm}$ (22.68-55.63 mbsf), which correspond to Subunit 1-2, with the exception of Sample 10P-4CC, 32-33 cm (31.99 mbsf), which is especially rich in benthic and planktonic foraminiferal shells. The benthic foraminifer assemblage in Sample 10P-4CC, $32-33 \mathrm{~cm}$, is diverse, and the most common species are C. carinata, $H$. balthica,
M. barleeanus, and Bulimina aculeata (Tables T11, T12). N. pachyderma (dextral) is the most abundant planktonic species (Table T11).

\section{Palynology}

A total of 26 samples (24 from core catchers and 2 from splitcore sections) were palynologically analyzed (Figure F14; Tables T13, T14); 13 samples are from lithostratigraphic Unit 1 , and 13 are from lithostratigraphic Unit 2. Palynomorphs are abundant in most samples studied, and preservation is good; however, in some samples, a significant number of corroded pollen grains were encountered (e.g., Samples 381-M0078A-99R-CC, $4 \mathrm{~cm}$ [283.81 mbsf], and $134 \mathrm{R}-\mathrm{CC}, 1 \mathrm{~cm}$ [428.64 mbsf]). It appears, though, that the high corroded pollen concentration does not correlate with a low concentration of well-preserved pollen grains. Corroded pollen grain concentration varies between a maximum of 7700 grains/g and a minimum of 41 grains/g with a mean value of 729 grains/g, and

Table T11. Benthic and planktonic foraminifer counts, Hole M0078B. Download table in CSV format.

Table T12. Relative abundances of benthic foraminifer species, Hole M0078B. Download table in CSV format.

Figure F14. Summary percentages and concentrations of selected terrestrial and aquatic pollen grains, fern spores, dinoflagellate cysts, green algae coenobia and spores, fungal remains, foraminifer test linings, and microscopic charred particles, Hole M0078A. Gray = marine subunits, dashed line $=$ Unit 1 (above)/2 (below) boundary.

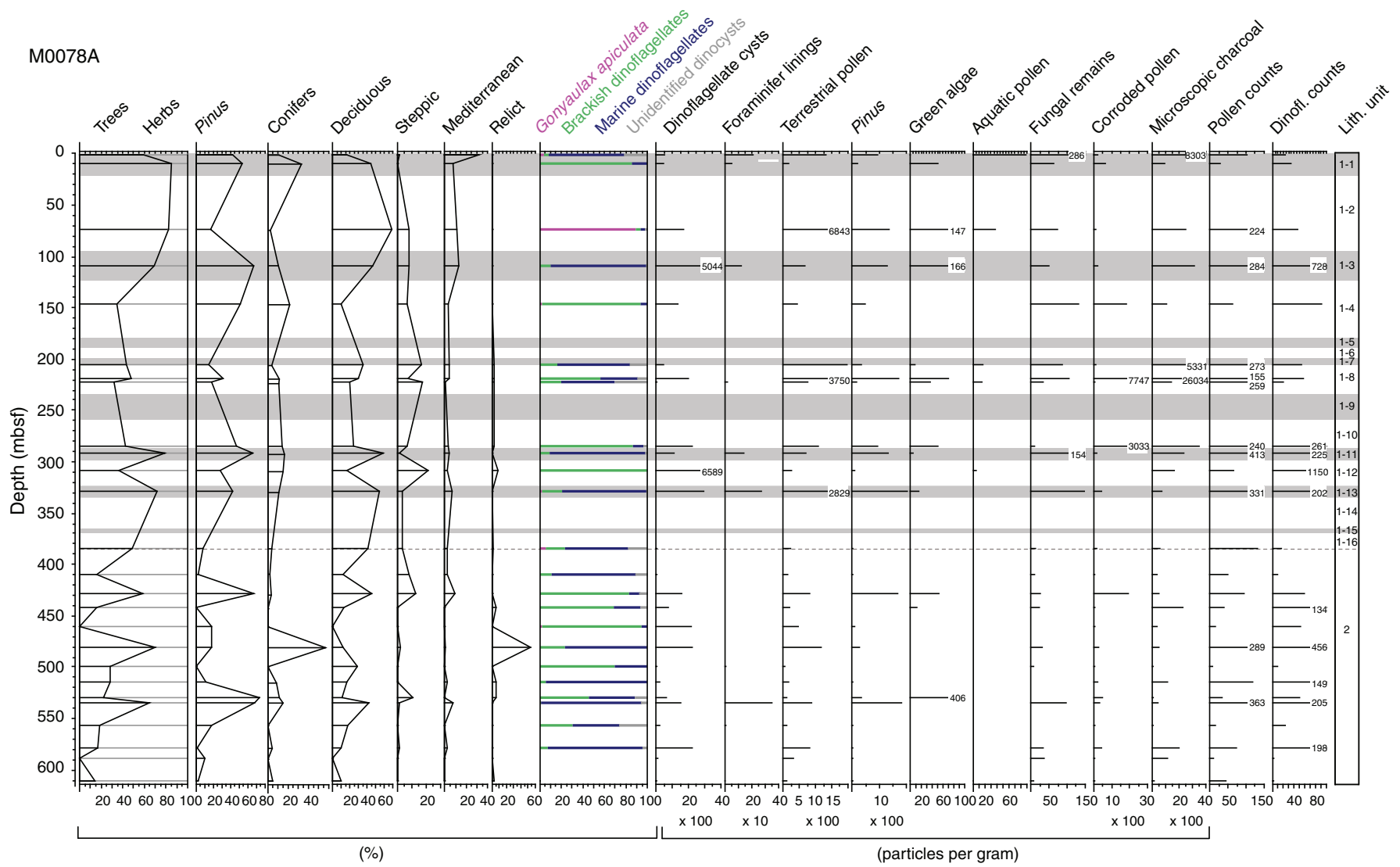

Table T13. Relative abundances of selected pollen grains, fern spores, dinoflagellate cysts, green algae coenobia and spores, fungal remains, foraminifer test linings, and microscopic charred particles, Site M0078. Download table in CSV format.

Table T14. Concentrations of selected pollen grains, fern spores, dinoflagellate cysts, green algae coenobia and spores, fungal remains, foraminifer test linings, and microscopic charred particles, Site M0078. Download table in CSV format. 
Table T15. Calcareous nannofossil biohorizons (low to middle latitudes) used to constrain age in Unit 1, Hole M0078A. NA = not available. FAD = first appearance datum, $L A D=$ last appearance datum, LDO = last downhole occurrence, $X=$ dominance crossover. Download table in CSV format.

\begin{tabular}{|c|c|c|c|c|c|c|c|}
\hline Occurrence & Biohorizon & $\begin{array}{l}\text { Age } \\
\text { (Ma) }\end{array}$ & $\begin{array}{c}\text { Nannofossil } \\
\text { zone }\end{array}$ & $\begin{array}{l}\text { Depth } \\
\text { (mbsf) }\end{array}$ & $\begin{array}{l}\text { Core, section, } \\
\text { interval }(\mathrm{cm})\end{array}$ & References & Note \\
\hline & & & & & 381-M0078A- & & \\
\hline$x$ & $\begin{array}{l}\text { Emiliania huxleyi to } \\
\text { Gephyrocapsa"small" }\end{array}$ & 0.07 & NN21/CNPL11 & $20.65-92.22$ & NA & $\begin{array}{l}\text { Anthonissen and Ogg, 2012; Backman } \\
\text { et al., 2012; Martini, } 1971\end{array}$ & Occurs in Subunit 1-2 \\
\hline LDO & Emiliania huxleyi & 0.29 & NN21/CNPL12 & 121.82 & $41 P-3,50-51$ & Backman et al., 2012; Martini, 1971 & LDO observed, not true FAD \\
\hline Single observation & Pseudoemiliania lacunosa & 0.43 & NN19/CNPL13 & 298.60 & $105 R-1,60$ & Backman et al., 2012 & Not true LAD \\
\hline
\end{tabular}

there appears to be a correlation between isolated/semi-isolated subunits and high corroded grain concentrations.

Fungal remains consisting of ascospores and fruit bodies, aquatic vascular plant grains and spores, and charred microscopic particles have a higher concentration in Unit 1. Terrestrial pollen concentration, including trees and herbs, is also higher in Unit 1 , with a mean value of 2500 grains/g, whereas Unit 2 has a mean value of 800 grains $/ g$. Green algae concentration, which is mainly composed of Botryococcus sp., Pediastrum spp., and Zygnemataceae, has a maximum of 400 coenobia/spores per gram in Unit 2 (Sample 156R-CC, 9 cm; 528.86 mbsf).

The trees versus herbs percentage curve shows alternating periods dominated by forests or herb vegetation (Figure F14). Tree and herb concentrations confirm the occurrence of forested and open landscapes in the borderlands of the Gulf of Corinth inferred by the percentages curves. It appears that some peaks in tree percentages may correspond to marine intervals; however, further research is required for confirmation. High pine percentages (calculated on the Pollen Sum including pines) in the samples studied correspond to high tree percentages. These findings suggest that pines are not overrepresented in the pollen spectra and most likely form a constituent element of the local vegetation. Nevertheless, pines are excluded from the Pollen Sum to ensure compatibility with other marine regional records (see Micropaleontology in the Expedition 381 methods chapter [McNeill et al., 2019b]).

Quercus spp. dominates the deciduous trees percentages in all samples examined, but other mesophilous trees such as Corylus, $\mathrm{Ul}$ mus, Carpinus, Tilia, and Acer are present. Pollen grains of Carya, Pterocarya, and Liquidambar (relict species curve on Figure F14) are encountered in both lithostratigraphic units in low abundances (see Table T13). Conifer relative percentages have a mean of $9.7 \%$; Cedrus is the dominant conifer species in Unit 2, and Abies is the dominant conifer species in Unit 1. In Sample 381-M0078A-146R-4, $9 \mathrm{~cm}$ (479.76 mbsf), Cedrus reaches a maximum of 50.7\%. Steppic elements (e.g., Artemisia and Ephedra), suggesting the occurrence of open landscape, are more abundant in Unit 1 and correspond to isolated/semi-isolated intervals. Mediterranean sclerophyllous vegetation increases toward the top of the record, reaching a maximum of $12.6 \%$ in Sample 381-M0078B-1P-1, 0 cm (0 mbsf). These findings depict the significant role of Mediterranean maquis in the modern vegetation surrounding the Gulf of Corinth.

Dinoflagellate cysts have a mean concentration of 1885 cysts/g in Unit 1 and 985 cysts/g in Unit 2, whereas species diversity varies significantly throughout the core. Samples with a high diversity of marine dinoflagellate species (e.g., halophilic Mediterranean Spiniferites sp., Nematosphaeropsis labyrinthus, Lingulodinium machaerophorum, and Operculodinium centrocarpum) suggest deposition under fully marine conditions (Mudie et al., 2010) (e.g., Samples 381-M0078A-37P-CC, $11 \mathrm{~cm}$ [108.75 mbsf]; 101R-CC, $17 \mathrm{~cm}$ [291.92 mbsf]; and 157R-4, $54 \mathrm{~cm}$ [534.33 mbsf]). Samples with lower dinocyst diversity dominated by low-salinity indicators, such as Pyxidinopsis psilata, Spiniferites cruciformis, and L. machaerophorum, with low processes suggest deposition under low-salinity (brackish) conditions (Mertens et al., 2012; Mudie et al., 2017) (e.g., Samples 99R-CC, $4 \mathrm{~cm}$ [283.81 mbsf], and 134R-CC, $1 \mathrm{~cm}$ [428.64 mbsf]). Cysts of the freshwater species Gonyaulax apiculata (Evitt et al., 1985; Kouli et al., 2001) have a maximum of 1500 cysts/g (Table T14) and an abundance of 89\% (Figure F14) in Sample 28H-CC, $10 \mathrm{~cm}$ (73.51 mbsf).

\section{Biostratigraphy summary}

Biostratigraphic age control is provided solely by calcareous nannofossils in Hole M0078A, and it should be applied cautiously given the complexity of the depositional environment (Table T15). Three biohorizons were recognized at this site. The first age datum is the crossover in dominance between E. huxleyi and Gephyrocapsa "small." This crossover has been observed in multiple locations (Thierstein et al., 1977; Raffi et al., 2006; Anthonissen and Ogg, 2012), including the Mediterranean region, where it is calibrated at 0.07 Ma in MIS 4 (Anthonissen and Ogg, 2012). If this datum can be applied accurately in Hole M0078A, then it occurs in Subunit 1-2.

The LDO of E. huxleyi in Sample 381-M0078A-41P-3, 50-51 $\mathrm{cm}$ (121.82 mbsf), likely does not represent the true FAD (0.29 Ma) because this species evolved during glacial MIS 8, a time when the Gulf of Corinth was presumably disconnected from the Mediterranean Sea.

The oldest marker, P. lacunosa (LAD at $0.43 \mathrm{Ma}$ ), was observed in Sample 381-M0078A-105R-1, 60 cm (298.6 mbsf). In addition to only being observed in one sample, this occurrence is likely not the true LAD because the extinction of $P$. lacunosa occurs in glacial MIS 12, a time when the Gulf of Corinth was presumably disconnected from the Mediterranean Sea.

\section{Micropaleontology summary}

Micropaleontology at Site M0078 revealed a high level of complexity both in individual microfossil groups and collectively. Unit 1 alternates primarily between marine and undetermined assemblages but also includes several intervals with mixed and nonmarine assemblages. Unit 2 is devoid of marine calcareous and silicate microfossils and contains only nonmarine diatoms and terrestrial and aquatic pollen, dinoflagellate cysts, green algae coenobia and spores, fungal remains, and foraminifer test linings. However, a distinct horizon in Unit 2 is characterized by a predominantly marine dinoflagellate cyst assemblage, and foraminifer test linings were more abundant. In both units, alternating periods of forested and open landscapes are inferred in the borderlands of the Gulf of Corinth. See Figures F15 and F16 for a summary of the microfossil assemblages in Holes M0078A and M0078B by subunit. 
Figure F15. Summary of micropaleontology assemblages by subunit, Hole M0078A. Blue = marine microfossil assemblages, green $=$ mixed microfossil assemblages, gray $=$ undetermined microfossil assemblages.

\begin{tabular}{|c|c|c|c|c|c|c|}
\hline Lith. unit & Subunit & Top depth (mbsf) & Base depth (mbsf) & Collective aquatic microfossil assemblage & Components of microfossil assemblage as of the OSP & Inferred dominant vegetation \\
\hline \multirow{16}{*}{1} & 1 & 0 & 20.78 & Marine assemblage & $\begin{array}{l}\text { Calcareous nannofossils, benthic foraminifers, } \\
\text { dinoflagellate cysts, green algae coenobia and spores, } \\
\text { foraminifer test linings, terrestrial and aquatic pollen } \\
\text { and spores, and fungal remains }\end{array}$ & $\begin{array}{l}\text { Mediterranean } \\
\text { schlerophyllous (top } \\
\text { horizon) }\end{array}$ \\
\hline & 2 & 20.78 & 94.14 & $\begin{array}{l}\text { Dominantly a mixed assemblage with } \\
\text { some undetermined and nonmarine } \\
\text { assemblages }\end{array}$ & $\begin{array}{l}\text { Calcareous nannofossils, nonmarine diatoms, } \\
\text { dinoflagellate cysts, green algae coenobia and spores, } \\
\text { terrestrial and aquatic pollen and spores, and fungal } \\
\text { remains }\end{array}$ & Mixed deciduous forest \\
\hline & 3 & 94.14 & 122.16 & $\begin{array}{l}\text { Dominantly a marine assemblage with } \\
\text { few undetermined intervals }\end{array}$ & $\begin{array}{l}\text { Calcareous nannofossils, planktonic and benthic } \\
\text { foraminifers, marine diatoms and other siliceous marine } \\
\text { microfossils, dinoflagellate cysts, green algae coenobia } \\
\text { and spores, terrestrial pollen and spores, and fungal } \\
\text { remains }\end{array}$ & Mixed deciduous forest \\
\hline & 4 & 122.16 & 180.14 & $\begin{array}{l}\text { Dominantly an undetermined assemblage } \\
\text { with one marine sample, one nonmarine } \\
\text { sample, and some mixed assemblages }\end{array}$ & $\begin{array}{l}\text { Dinoflagellate cysts combined with low concentrations } \\
\text { of calcareous nannofossils, marine and nonmarine } \\
\text { diatoms, planktonic and benthic foraminifers, terrestrial } \\
\text { pollen and spores, and fungal remains }\end{array}$ & Open/meadow vegetation \\
\hline & 5 & 180.14 & 188.18 & Marine assemblage & $\begin{array}{l}\text { Calcareous nannofossils, planktonic and benthic } \\
\text { foraminifers, and marine diatoms }\end{array}$ & \\
\hline & 6 & 188.18 & 199.14 & $\begin{array}{l}\text { Dominantly an undetermined assemblage } \\
\text { with one mixed assemblage sample }\end{array}$ & $\begin{array}{l}\text { Low concentrations of benthic and planktonic } \\
\text { foraminifers, calcareous nannofossils, and nonmarine } \\
\text { diatoms }\end{array}$ & \\
\hline & 7 & 199.14 & 206.40 & $\begin{array}{l}\text { Dominantly a marine assemblage with } \\
\text { one undetermined sample }\end{array}$ & $\begin{array}{l}\text { Calcareous nannofossils, planktonic and benthic } \\
\text { foraminifers, marine diatoms and other siliceous } \\
\text { microfossils, dinoflagellate cysts, green algae coenobia } \\
\text { and spores, terrestrial and aquatic pollen and spores, } \\
\text { and fungal remains }\end{array}$ & Mixed deciduous forest \\
\hline & 8 & 206.40 & 236.18 & $\begin{array}{l}\text { Dominantly an undetermined assemblage } \\
\text { with one marine sample }\end{array}$ & $\begin{array}{l}\text { Dinoflagellate cysts, green algae coenobia and spores, } \\
\text { and foraminifer test linings combined with low } \\
\text { concentrations of planktonic and benthic foraminifers, } \\
\text { calcareous nannofossils, and nonmarine diatoms, } \\
\text { terrestrial and aquatic pollen and spores, and fungal } \\
\text { remains }\end{array}$ & Grassland \\
\hline & 9 & 236.18 & 260.70 & $\begin{array}{l}\text { Dominantly a marine assemblage with } \\
\text { one undetermined sample }\end{array}$ & $\begin{array}{l}\text { Calcareous nannofossils, planktonic and benthic } \\
\text { foraminifers, marine diatoms, and other siliceous } \\
\text { microfossils }\end{array}$ & \\
\hline & 10 & 260.70 & 287.12 & $\begin{array}{l}\text { Dominantly an undetermined assemblage } \\
\text { with one mixed assemblage sample }\end{array}$ & $\begin{array}{l}\text { Dinoflagellate cysts, green algae coenobia and spores, } \\
\text { and nonmarine diatoms combined with low } \\
\text { concentrations of calcareous nannofossils, benthic and } \\
\text { planktonic foraminifers, terrestrial pollen and spores, } \\
\text { and fungal remains }\end{array}$ & Grassland \\
\hline & 11 & 287.12 & 298.84 & $\begin{array}{l}\text { Dominantly a marine assemblage with } \\
\text { two undetermined intervals }\end{array}$ & $\begin{array}{l}\text { Calcareous nannofossils, benthic and planktonic } \\
\text { foraminifers, dinoflagellate cysts, green algae coenobia } \\
\text { and spores, foraminifer test linings, terrestrial pollen } \\
\text { and spores, and fungal remains }\end{array}$ & Mixed deciduous forest \\
\hline & 12 & 298.84 & 322.35 & Undetermined microfossil assemblage & $\begin{array}{l}\text { Dinoflagellate cysts with low concentrations of } \\
\text { calcareous nannofossils, planktonic and benthic } \\
\text { foraminifers, and terrestrial pollen and spores }\end{array}$ & \\
\hline & 13 & 322.35 & 334.40 & $\begin{array}{l}\text { Dominantly a marine assemblage with } \\
\text { one undetermined interval }\end{array}$ & $\begin{array}{l}\text { Calcareous nannofossils, benthic foraminifers, } \\
\text { dinoflagellate cysts, green algae coenobia and spores, } \\
\text { and foraminifer test linings combined with low } \\
\text { concentrations of marine diatoms and other siliceous } \\
\text { microfossils, and terrestrial and aquatic pollen and } \\
\text { spores }\end{array}$ & Mixed deciduous forest \\
\hline & 14 & 334.40 & 366.49 & $\begin{array}{l}\text { Undetermined assemblage with one } \\
\text { nonmarine interval }\end{array}$ & $\begin{array}{l}\text { One nonmarine diatom bloom with low concentrations } \\
\text { of calcareous nannofossils, marine diatoms, planktonic } \\
\text { and benthic foraminifers, dinoflagellate cysts, and } \\
\text { terrestrial pollen and spores }\end{array}$ & \\
\hline & 15 & 366.49 & 369.66 & Marine assemblage & $\begin{array}{l}\text { Calcareous nannofossils, benthic and planktonic } \\
\text { foraminifers, marine diatoms, and other siliceous } \\
\text { microfossils }\end{array}$ & \\
\hline & 16 & 369.66 & 385.14 & Undetermined assemblage & $\begin{array}{l}\text { Low concentrations of calcareous nannofossils, } \\
\text { nonmarine diatoms, benthic and planktonic foraminifers, } \\
\text { and terrestrial and aquatic palynomorphs }\end{array}$ & Open/meadow vegetation \\
\hline 2 & & 385.14 & 610.43 & $\begin{array}{l}\text { Dominantly undetermined assemblages } \\
\text { with intervals of nonmarine and brackish } \\
\text { assemblages, and one marine sample }\end{array}$ & $\begin{array}{l}\text { Nonmarine diatoms, dinoflagellate cysts, green algae } \\
\text { coenobia and spores, foraminifer test linings, and } \\
\text { terrestrial pollen and spores }\end{array}$ & $\begin{array}{l}\text { Intervals with open-meadow } \\
\text { vegetation, Cedrus forest, } \\
\text { and mixed deciduous forest }\end{array}$ \\
\hline
\end{tabular}

Figure F16. Summary of micropaleontology assemblages by subunit, Hole M0078B. Blue = marine microfossil assemblages, green $=$ mixed microfossil assemblages.

\begin{tabular}{|c|r|r|r|r|l|l|}
\hline Lith. unit & Subunit & Top depth (mbsf) & Base depth (mbsf) & Collective aquatic microfossil assemblage & Components of microfossil assemblage as of the OSP & Inferred dominant vegetation \\
\hline 1 & 0 & 20.78 & Marine assemblage & $\begin{array}{l}\text { Calcareous nannofossils, benthic foraminifers, } \\
\text { dinoflagellate cysts, green algae coenobia and spores, } \\
\text { foraminifer test linings, terrestrial and aquatic pollen } \\
\text { and spores, and fungal remains }\end{array}$ & $\begin{array}{l}\text { Mediterranean } \\
\text { schlerophyllous (top } \\
\text { horizon) }\end{array}$ \\
\cline { 2 - 6 } & 2 & 20.78 & 94.14 & $\begin{array}{l}\text { Dominantly a mixed assemblage with } \\
\text { some undetermined and nonmarine } \\
\text { assemblages }\end{array}$ & $\begin{array}{l}\text { Calcareous nannofossils, nonmarine diatoms, and } \\
\text { benthic foraminifers }\end{array}$ & \begin{tabular}{l} 
No samples analyzed \\
\hline
\end{tabular} \\
\cline { 2 - 6 } & & & &
\end{tabular}




\section{Geochemistry}

\section{Interstitial water}

At Site M0078, 82 interstitial water samples were collected using Rhizon samplers and whole-round squeeze cakes from both holes. Rhizons were used from 0.01 to $18.81 \mathrm{mbsf}$, and squeeze cakes were used from 11.78 to $608.80 \mathrm{mbsf}$ in Hole M0078A. Hole M0078B penetrated $55.85 \mathrm{~m}$, and Rhizons successfully collected pore water from the sediment/water interface to $8.56 \mathrm{mbsf}$. Five additional squeeze cakes were used to collect pore water from 12.00 to 52.51 mbsf in Hole M0078B (Table T16). Fluid geochemical results from both holes closely match for all analytes and are generally discussed together except where noted. Additionally, 14 drilling mud fluid samples were collected from discrete depths between 11.88 and 586.01 mbsf (see Geochemistry in the Expedition 381 methods chapter [McNeill et al., 2019b]) to identify the presence of any potential drilling contamination. No contamination was observed, as discussed below.

Pore water chemical compositions at Site M0078 reflect environmental changes in basin water chemistry, type and rate of organic matter burial, and dissolution/precipitation reactions with sediment. Two distinct geochemical regions were observed above and below the unit boundary (see Lithostratigraphy) at 385.14 mbsf. Cyclicity in the pore water signals is apparent in Unit 1 and may represent successive sea level fluctuations and basin water body isolation in the Gulf of Corinth. Unit 2 is broadly characterized by increasing concentrations of most solutes to the deepest sampled interval. These regions are described in detail below.

\section{Salinity variations: salinity, sodium, and chloride}

Salinity at Site M0078 decreases below the sediment/water interface from seawater values to 7.55 at 42.50 mbsf. Deeper than $42.50 \mathrm{mbsf}$, salinity values gradually decrease to a minimum of 1.95 at $340.34 \mathrm{mbsf}$ then increase to 19.65 at $608.80 \mathrm{mbsf}$. These broad changes are superimposed by smaller scale fluctuations that coincide with identified lithologic changes (e.g., Figure F17A). Thus, these smaller scale changes are generally interpreted to be true geochemical signals rather than analytical scatter.

The chloride $\left(\mathrm{Cl}^{-}\right)$profile closely follows the salinity profile throughout Site $\mathrm{M} 0078 . \mathrm{Cl}^{-}$concentration is highest (610.72 mM) close to the sediment/water interface (Figure F17B). $\mathrm{Cl}^{-}$decreases in the upper $30.45 \mathrm{~m}$ to $176.68 \mathrm{mM}$, followed by a more gradual decrease to $34.65 \mathrm{mM}$ at $282.10 \mathrm{mbsf}$. This trend with depth may reflect the integrated result of varying basin water salinity conditions in the Gulf of Corinth. Deeper than $340.34 \mathrm{mbsf}, \mathrm{Cl}^{-}$increases to a maximum of $310.38 \mathrm{mM}$ at $604.27 \mathrm{mbsf}$. As seen in Table T16, mud fluid salinity values throughout Hole M0078A are markedly different from sediment interstitial fluids, implying no contamination.

Figure F17C illustrates that salinity determined by refractometer (see Geochemistry in the Expedition 381 methods chapter [McNeill et al., 2019b]) is comparable with salinity calculated from $\mathrm{Cl}^{-}$ (assuming a salinity of 35 has a $\mathrm{Cl}^{-}$concentration of $558 \mathrm{mM}$ ), which provides evidence that $\mathrm{NaCl}$ is the dominant dissolved salt and other salts are minor contributors to pore water salinity at Site M0078.

\section{Organic matter degradation: alkalinity, ammonium, boron, bromide, iron, manganese, $\mathrm{pH}$, phosphate, sulfate, inorganic carbon, and sulfide}

Microbial mineralization of organic matter leads to distinct changes in pore water geochemistry, reflecting ongoing diagenetic
Table T16. Interstitial water geochemistry results, Site M0078. Download table in CSV format.

Figure F17. Pore water (A) salinity, (B) chloride, and (C) $\mathrm{Cl}^{-}$-based salinity. Black $=$ Hole M0078A, red $=$ Hole M0078B Gray $=$ marine subunits, black line = Unit 1 (above)/2 (below) boundary.

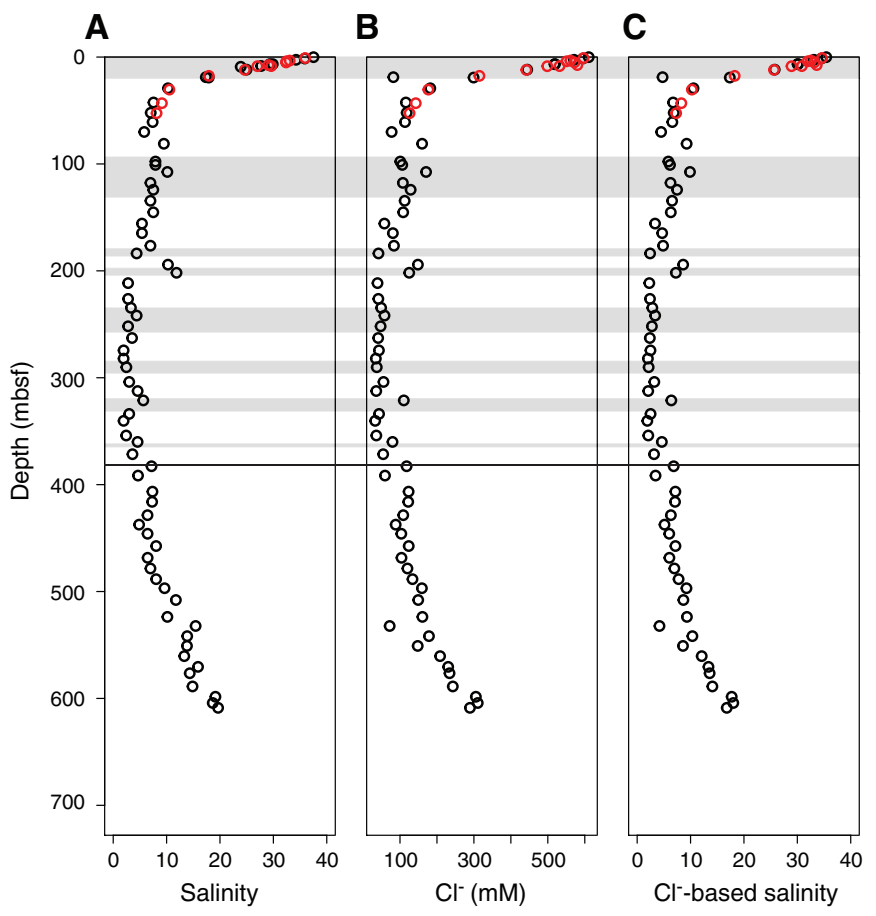

redox reactions (Berner, 1980; C.M. Miller et al., unpubl. data). Shallow pore water profiles in Hole M0078A suggest the typical sequence of organic matter degradation in marine sediments through microbial oxidation (Froelich et al., 1979). Elevated manganese $\left(\mathrm{Mn}^{2+}\right)$ concentration (as high as 67.04 $\mu \mathrm{M}$ ) indicates Mn oxide reduction in the upper $8.36 \mathrm{~m}$ of Holes M0078A and M0078B (Figure F18A). Dissolved iron $\left(\mathrm{Fe}^{2+}\right)$ concentration is elevated (as high as $172.25 \mu \mathrm{M}$ ) from 0.10 to $52.13 \mathrm{mbsf}$ in Hole M0078A, suggesting the reduction of $\mathrm{Fe}$ (oxy)hydroxides. However, in this interval, a zone of lower $\mathrm{Fe}^{2+}$ concentration occurs between 9.10 and 19.19 mbsf (Figure F18B). Sulfate $\left(\mathrm{SO}_{4}{ }^{2-}\right)$ concentration decreases from seawater values near the seafloor to $0.04 \mathrm{mM}$ at $11.78 \mathrm{mbsf}$, indicating $\mathrm{SO}_{4}{ }^{2-}$ reduction coupled to either organic matter degradation or anaerobic methane oxidation. Deeper than $11.78 \mathrm{mbsf}, \mathrm{SO}_{4}{ }^{2-}$ concentration generally stays between 0.02 and $4.85 \mathrm{mM}$, but multiple small peaks correspond to the previously described salinity fluctuations (Figure F18C). Sulfide $\left(\mathrm{HS}^{-}\right)$concentration values estimated by the difference between dissolved inorganic carbon (DIC) and alkalinity in Hole M0078A suggest the presence of $\mathrm{HS}^{-}$in the shallowest $200 \mathrm{~m}$ of the hole. $\mathrm{HS}^{-}$peaks at $\sim 40 \mathrm{mbsf}$ in Holes M0078A and M0078B and between 523.73 and 576.44 mbsf in Hole M0078A, where DIC is lower than alkalinity (Figure F19C).

Microbial processes of organic matter degradation release bicarbonate $\left(\mathrm{HCO}_{3}{ }^{-}\right)$, phosphate $\left(\mathrm{PO}_{4}{ }^{3-}\right)$, and ammonium $\left(\mathrm{NH}_{4}{ }^{+}\right)$to pore water. This process is apparent in the pore water results (Figure F19). $\mathrm{NH}_{4}{ }^{+}$concentration increases from seafloor values $(0.1 \mathrm{mM})$ to a local maximum of $2.6 \mathrm{mM}$ at $30.45 \mathrm{mbsf}$. $\mathrm{NH}_{4}{ }^{+}$then remains relatively constant (between 1.7 and $2.7 \mathrm{mM}$ ) to $211.47 \mathrm{mbsf}$ and then steadily increases to the base of Hole M0078A, with a maxi- 
Figure F18. Pore water (A) manganese, $(B)$ iron, and (C) sulfate. Black $=$ Hole M0078A, red $=$ Hole M0078B. Gray $=$ marine subunits, black line $=$ Unit 1 (above)/2 (below) boundary.

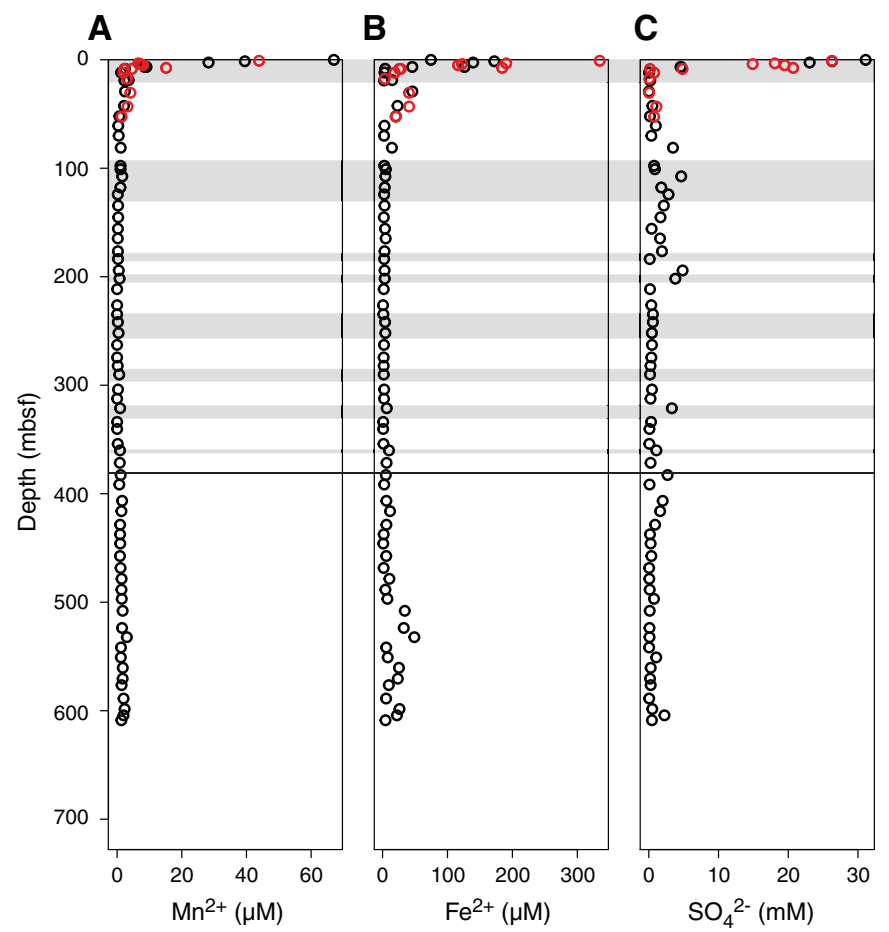

Figure F19. Pore water (A) ammonium, (B) phosphate, and (C) alkalinity and DIC (blue crosses). Black $=$ Hole M0078A, red $=$ Hole M0078B. Gray $=$ marine subunits, black line $=$ Unit 1 (above) $/ 2$ (below) boundary.

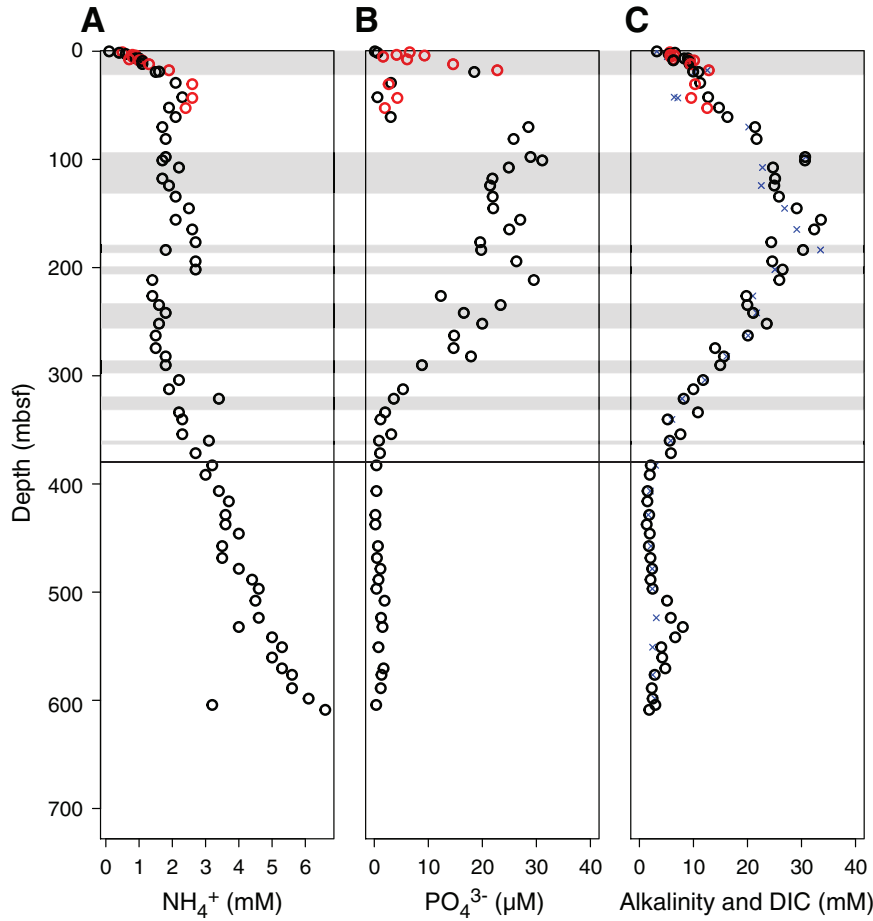

Figure F20. Pore water (A) $\mathrm{pH}$, (B) $\mathrm{B} / \mathrm{Cl}^{-}$ratio, and (C) $\mathrm{Br}^{-} / \mathrm{Cl}^{-}$ratio. Black $=$ Hole M0078A, red $=$ Hole M0078B. Gray = marine subunits, solid line $=$ Unit 1 (above)/2 (below) boundary. Dashed line = seawater values.

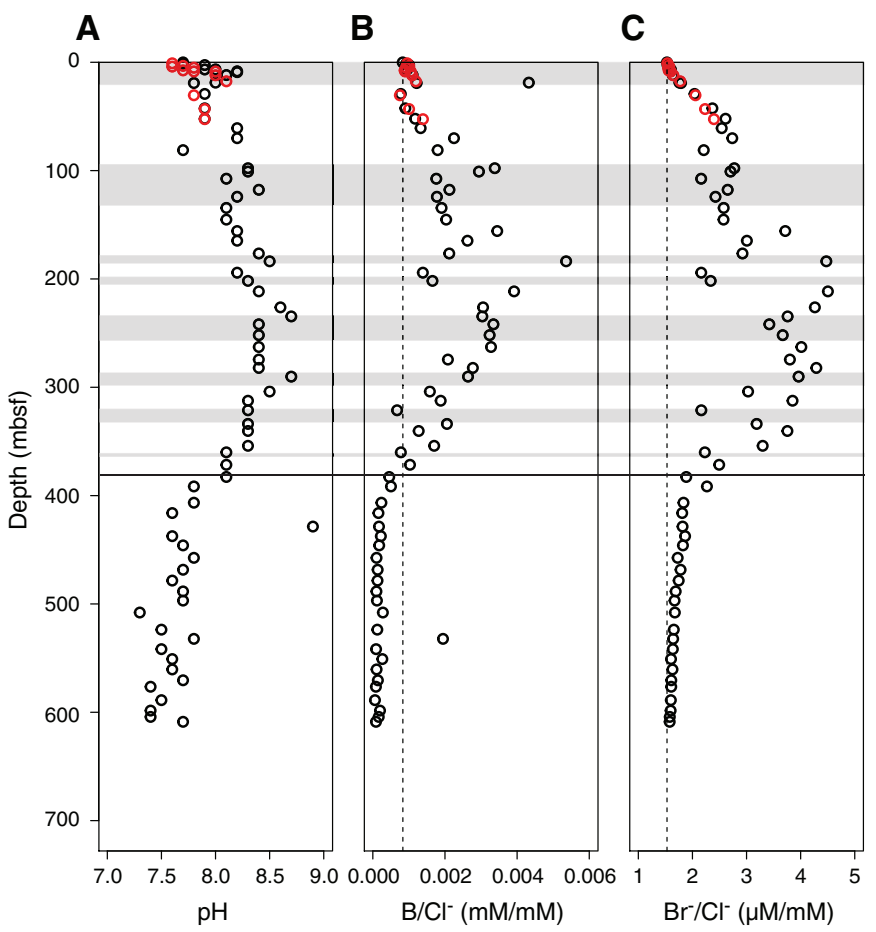

mum of $6.6 \mathrm{mM}$. In contrast to $\mathrm{NH}_{4}^{+}$, the $\mathrm{PO}_{4}{ }^{3-}$ increase in the uppermost portion of the core is more variable. Although $\mathrm{PO}_{4}{ }^{3-}$ concentration generally increases from $0.11 \mu \mathrm{M}$ at the sediment/water interface to $31.09 \mu \mathrm{M}$ at $100.91 \mathrm{mbsf}$, it is also low between 29.22 and $60.81 \mathrm{mbsf}$, which approximately corresponds to an isolated/semi-isolated subunit. At greater depths, $\mathrm{PO}_{4}{ }^{3-} \mathrm{de}-$ creases to $340.34 \mathrm{mbsf}$ and then remains consistently low to the base of the hole, fluctuating between 0.21 and $1.91 \mu \mathrm{M}$. $\mathrm{PO}_{4}{ }^{3-}$ concentration values are at their lowest at the base of the hole.

Similar to $\mathrm{PO}_{4}{ }^{3-}$, alkalinity increases with depth in the upper part of Hole M0078A, reaching a peak of $33.60 \mathrm{mM}$ at $155.77 \mathrm{mbsf}$ (Figure F19C). This peak is followed by decreasing alkalinity to 1.92 $\mathrm{mM}$ at $382.80 \mathrm{mbsf}$, approximately coincident with the lithostratigraphic Unit $1 / 2$ boundary. An additional front occurs from 523.73 to $550.88 \mathrm{mbsf}$, reaching a maximum of $8.04 \mathrm{mM}$. Broadly, the changes in alkalinity are reflected in $\mathrm{pH}$. Pore water $\mathrm{pH}$ at Site M0078 ranges from 7.0 to 8.9 with an average of 8.0 (Figure F20A). $\mathrm{pH}$ is generally higher above the Unit $1 / 2$ boundary, with a maximum at $234.58 \mathrm{mbsf}$ (deeper than the alkalinity peak), whereas $\mathrm{pH}$ is significantly lower below the unit boundary.

Boron (B) and bromide $\left(\mathrm{Br}^{-}\right)$accumulate in organic matter and are useful when compared with $\mathrm{Cl}^{-}$to determine relative contributions of seawater and organic carbon oxidation to pore water chemistry. Disparity of the $\mathrm{B} / \mathrm{Cl}^{-}$and $\mathrm{Br}^{-} / \mathrm{Cl}^{-}$ratios from seawater values can indicate production or removal of ions from solution. Both $\mathrm{B} / \mathrm{Cl}^{-}$and $\mathrm{Br}^{-} / \mathrm{Cl}^{-}$values broadly follow the $\mathrm{PO}_{4}{ }^{3-}$ profile with depth, including a change to lower values at the approximate location of the Unit $1 / 2$ boundary. The $\mathrm{B} / \mathrm{Cl}^{-}$and $\mathrm{Br}^{-} / \mathrm{Cl}^{-}$peak values 
are located deeper than the $\mathrm{PO}_{4}{ }^{3-}$ peak at 211.47 mbsf (Figures F19, F20). Drilling fluid concentrations of $\mathrm{Mn}^{2+}, \mathrm{NO}_{3}{ }^{-}, \mathrm{Fe}^{2+}, \mathrm{SO}_{4}{ }^{2-}$, $\mathrm{HCO}_{3}{ }^{-}, \mathrm{PO}_{4}{ }^{3-}, \mathrm{NH}_{4}{ }^{+}, \mathrm{B}$, and $\mathrm{Br}^{-}$are all dissimilar to those described above (Table T16), implying these samples are free of contamination.

\section{Mineral reactions}

Sodium, potassium, magnesium, calcium, strontium, and barium

Sodium $\left(\mathrm{Na}^{+}\right)$, potassium $\left(\mathrm{K}^{+}\right)$, magnesium $\left(\mathrm{Mg}^{2+}\right)$, and calcium $\left(\mathrm{Ca}^{2+}\right)$ are all major ions in seawater, and strontium $\left(\mathrm{Sr}^{2+}\right)$ and barium $\left(\mathrm{Ba}^{2+}\right)$ are minor components. Pore water solute concentration may be altered by ion exchange, mineral weathering, and formation of new minerals. The $\mathrm{Na}^{+}$and $\mathrm{K}^{+}$depth profiles resemble those of salinity and $\mathrm{Cl}^{-}$, indicating that salinity changes govern the overall pattern (Figure F21). However, the $\mathrm{Na}^{+} / \mathrm{Cl}^{-}$and $\mathrm{K}^{+} / \mathrm{Cl}^{-}$ratios show their concentrations may also be influenced by reactions with sediment because the ratios differ downhole and do not reflect the modern Gulf of Corinth seawater composition (vertical dashed lines, Figure F21). Between 60.84 and 290.15 mbsf, the $\mathrm{Na}^{+} / \mathrm{Cl}^{-}$and $\mathrm{K}^{+} / \mathrm{Cl}^{-}$ratios are higher than seawater, suggesting the release of $\mathrm{Na}^{+}$ and $\mathrm{K}^{+}$to the pore water. Deeper than $354.04 \mathrm{mbsf}$ (31 $\mathrm{m}$ above the Unit $1 / 2$ boundary), the $\mathrm{Na}^{+} / \mathrm{Cl}^{-}$and $\mathrm{K}^{+} / \mathrm{Cl}^{-}$ratios are lower than in seawater. $\mathrm{Ba}^{2+}$ shows opposing trends to salinity in the uppermost $30 \mathrm{mbsf}$, increasing from 0.31 to $18.00 \mu \mathrm{M}$. However, from 340.34

Figure F21. Pore water (A) sodium, (B) potassium, and (C) barium and (D) $\mathrm{Na}^{+} / \mathrm{Cl}^{-}$, (E) $\mathrm{K}^{+} / \mathrm{Cl}^{-}$, and (F) $\mathrm{Ba}^{2+} / \mathrm{Cl}^{-}$ratios. Black = Hole M0078A, red = Hole M0078B. Gray = marine subunits, solid line = Unit 1 (above)/2 (below) boundary. Dashed line = seawater values.
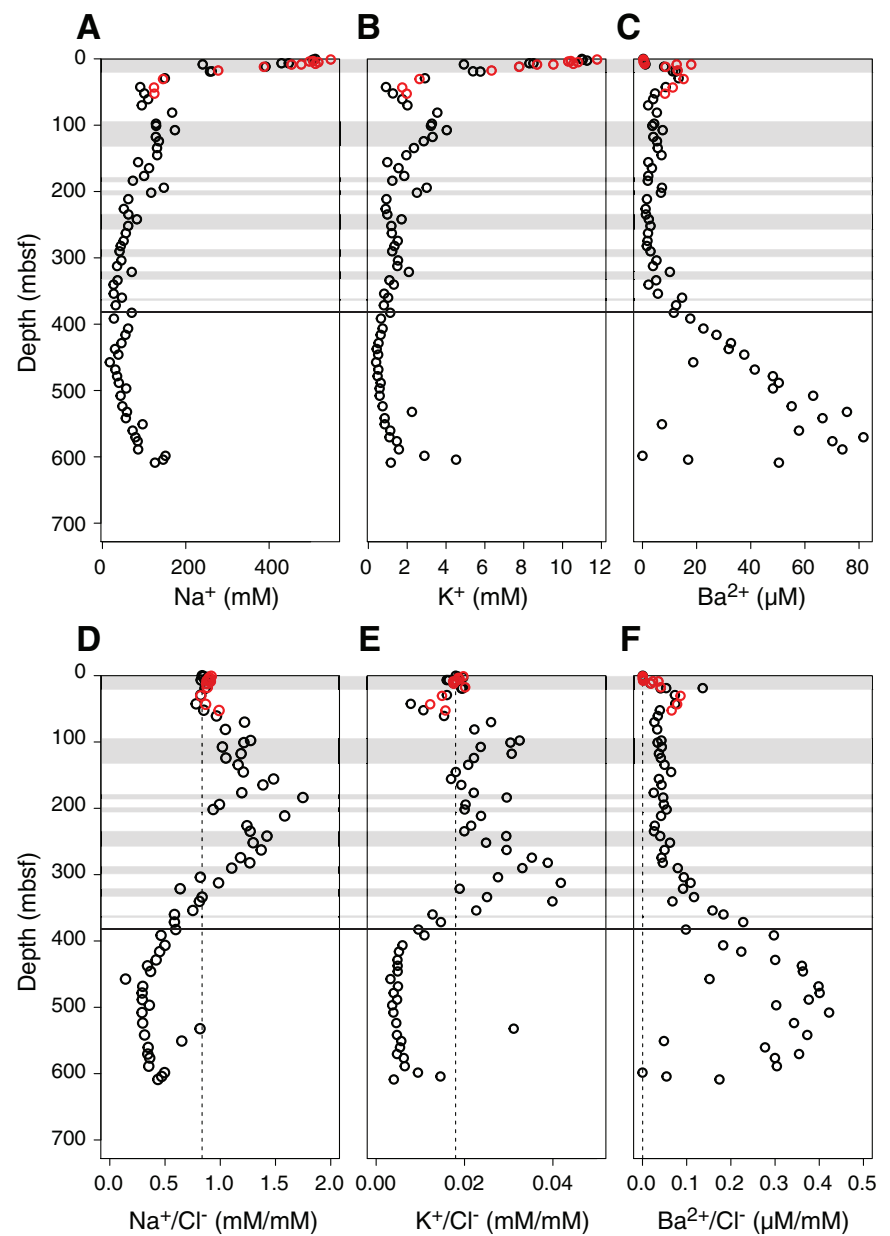

mbsf ( $45 \mathrm{~m}$ above the Unit $1 / 2$ boundary) downhole, $\mathrm{Ba}^{2+}$ increases alongside the increasing salinity to a maximum of $81.63 \mu \mathrm{M}$ at 570.46 mbsf. This increase deeper than 340.34 mbsf appears to not entirely be governed by salinity, as emphasized in the $\mathrm{Ba}^{2+} / \mathrm{Cl}^{-}$ratio, which is higher than modern Gulf of Corinth seawater composition.

The dissolved $\mathrm{Ca}^{2+}, \mathrm{Mg}^{2+}$, and $\mathrm{Sr}^{2+}$ depth profiles largely follow the $\mathrm{Cl}^{-}$curve (Figures F17B, F22A-F22C). $\mathrm{Ca}^{2+}$ decreases in the uppermost 11.78 mbsf from 9.37 to $1.83 \mathrm{mM}$. A peak at $30.45 \mathrm{mbsf}$ may indicate an additional source from the depth at which $\mathrm{Ca}^{2+}$ is released. Between 100.91 and $312.42 \mathrm{mbsf}, \mathrm{Ca}^{2+}$ concentration stays lower than $1.6 \mathrm{mM} . \mathrm{Mg}^{2+}$ also decreases from the top of Site M0078 and stays between 1.35 and $11.60 \mathrm{mM}$ from 100.91 to $312.42 \mathrm{mbsf}$. $\mathrm{Sr}^{2+}$ concentration also decreases in the upper $11.78 \mathrm{mbsf}$ but has the same additional peak as $\mathrm{Ca}^{2+}$ at $30.45 \mathrm{mbsf}^{2} \mathrm{Sr}^{2+}$ stays lower than $50 \mu \mathrm{M}$ in the 100.91-312.42 mbsf interval. Deeper than 340.34 mbsf, all profiles increase. At the base of Hole M0078A, $\mathrm{Mg}^{2+}$ concentration returns to approximate seawater values, whereas $\mathrm{Ca}^{2+}$ and $\mathrm{Sr}^{2+}$ concentrations increase to several times higher than modern seawater values (vertical dashed lines, Figure F22).

The $\mathrm{Ca}^{2+} / \mathrm{Cl}^{-}$and $\mathrm{Mg}^{2+} / \mathrm{Cl}^{-}$ratios are mostly lower than seawater values from the sediment/water interface to $303.93 \mathrm{mbsf}$ (Figure F22D-F22E). The $\mathrm{Sr}^{2+} / \mathrm{Cl}^{-}$ratio stays close to the seawater ratio in the upper $303.93 \mathrm{mbsf}$ (Figure F22F). Deeper than $303.93 \mathrm{mbsf}$, the $\mathrm{Ca}^{2+} / \mathrm{Cl}^{-}, \mathrm{Mg}^{2+} / \mathrm{Cl}^{-}$, and $\mathrm{Sr}^{2+} / \mathrm{Cl}^{-}$ratios increase to values much

Figure F22. Pore water (A) calcium, (B) magnesium, and (C) strontium and (D) $\mathrm{Ca}^{2+} / \mathrm{Cl}^{-}$, (E) $\mathrm{Mg}^{2+} / \mathrm{Cl}^{-}$, and ( $\left.\mathrm{F}\right) \mathrm{Sr}^{2+} / \mathrm{Cl}^{-}$ratios. Black $=$Hole M0078A, red = Hole M0078B. Gray = marine subunits, solid line $=$ Unit 1 (above)/2 (below) boundary. Dashed line = seawater values.
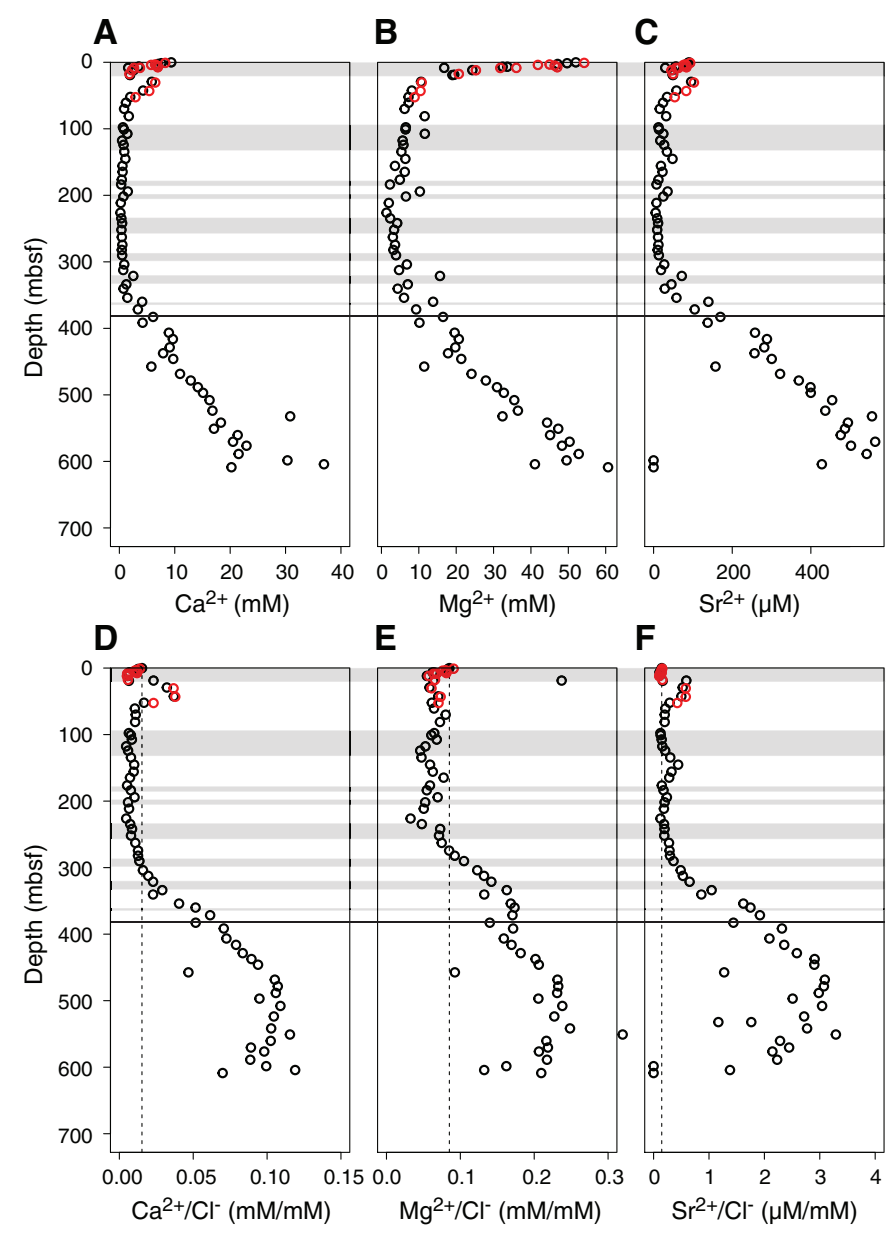
higher than seawater, suggesting a source for $\mathrm{Ca}^{2+}, \mathrm{Mg}^{2+}$, and $\mathrm{Sr}^{2+}$ ions deeper than the cored section.

\section{Silica and lithium}

Silica accumulates in sediments from terrigenous silicate minerals and the remnants of siliceous organisms living in the water column (dominantly diatoms and radiolarians). Therefore, dissolved silica $\left(\mathrm{H}_{4} \mathrm{SiO}_{4}\right)$ is typically released to pore water through dissolution of sediment components. $\mathrm{H}_{4} \mathrm{SiO}_{4}$ concentration is between 124.34 and $274.00 \mu \mathrm{M}$ from below the sediment/water interface to $11.78 \mathrm{mbsf}$ at Site M0078 (Figure F23A). Between 18.81 and 371.54 mbsf, $\mathrm{H}_{4} \mathrm{SiO}_{4}$ is higher with a maximum of $1227.88 \mu \mathrm{M}$ at 97.74 mbsf. In this zone, dissolved Si content fluctuates, which may be a result of varying initial silicate content in the sediment. Between 382.80 and 468.43 mbsf, concentration is low (between 133.20 and $198.52 \mu \mathrm{M})$ and relatively steady before increasing again to higher values at $478.43 \mathrm{mbsf}$. In this lower portion of the hole, fluctuations are comparable in magnitude with those visible between 18.17 and 371.54 mbsf. Lithium $\left(\mathrm{Li}^{+}\right)$concentration is consistently low above the Unit $1 / 2$ boundary and increases gradually below the boundary to $480.44 \mu \mathrm{M}$ in the deepest sample (604.27 mbsf) (Figure F23B). This increase with depth suggests chemical weathering of the sediment.

\section{Sediment}

\section{Carbon content}

At Site M0078, 127 total carbon (TC) and total organic carbon (TOC) content samples were collected and analyzed. Total inorganic carbon (TIC) was obtained by subtracting TOC from TC. The results are presented in Table T17 and plotted against depth in Figure F24. Site M0078 TC varies between 4.54 and $10.62 \mathrm{wt} \%$ with an average of $7.54 \mathrm{wt} \%$. Values below the Unit $1 / 2$ boundary are significantly higher, which is confirmed by the energy dispersive X-ray fluorescence (ED-XRF) discussed below and by XRD measurements (see Lithostratigraphy). TOC varies between 0.08 and 0.89 wt $\%$ with an average of $0.31 \pm 0.12 \mathrm{wt} \%$ (standard deviation). Peaks in TOC at 104.70, 180.86, 203.08, 220.40, 236.91-253.79, 291.67, 325.1 , and 368.7 mbsf correspond to the interpreted marine subunits (see Lithostratigraphy; gray bars, Figure F24B).

\section{ED-XRF}

The concentrations of 24 elements were measured in the same 127 sediment samples collected for TC, TIC, and TOC from Site M0078 (109 samples from Hole M0078A and 18 samples from Hole M0078B). For 11 elements (Al, Ca, Fe, K, Mg, Mn, Si, Sr, Zr, Ni, and $\mathrm{Rb}$ ), quantitative contents were measured (Table T17; Figures F25, F26, F27, and F28). For the other elements, either contents were too low or the measurement was imprecise because of interferences of the spectra. Hence, no precise, reliable results could be given for these elements. For all elements, considerable differences between Units 1 and 2 are apparent.

The highest elemental content was measured for calcium (Figure F25A). At Site M0078, an average Ca concentration of 214.3 $\mathrm{g} / \mathrm{kg}$ was measured. Large differences were apparent between the two lithostratigraphic units: the average concentration in Unit 1 is $194 \mathrm{~g} / \mathrm{kg}$, whereas significantly higher values $(289.3 \mathrm{~g} / \mathrm{kg})$ are detected in Unit 2 . The second most abundant measured element was $\mathrm{Si}($ mean $=119.7 \mathrm{~g} / \mathrm{kg})$ (Figure F26A). The Spearman Rho correlation between these two major elements shows an almost ideal negative correlation $(R=-0.95, p<0.05)$. Very strong positive correlations $(R>0.84)$ also exist between $\mathrm{Si}$ and $\mathrm{Al}, \mathrm{K}, \mathrm{Rb}, \mathrm{Zr}, \mathrm{Fe}$,
Figure F23. Pore water (A) dissolved silica and (B) lithium. Black $=$ Hole M0078A, red $=$ Hole M0078B. Gray $=$ marine subunits, black line $=$ Unit 1 (above)/2 (below) boundary.

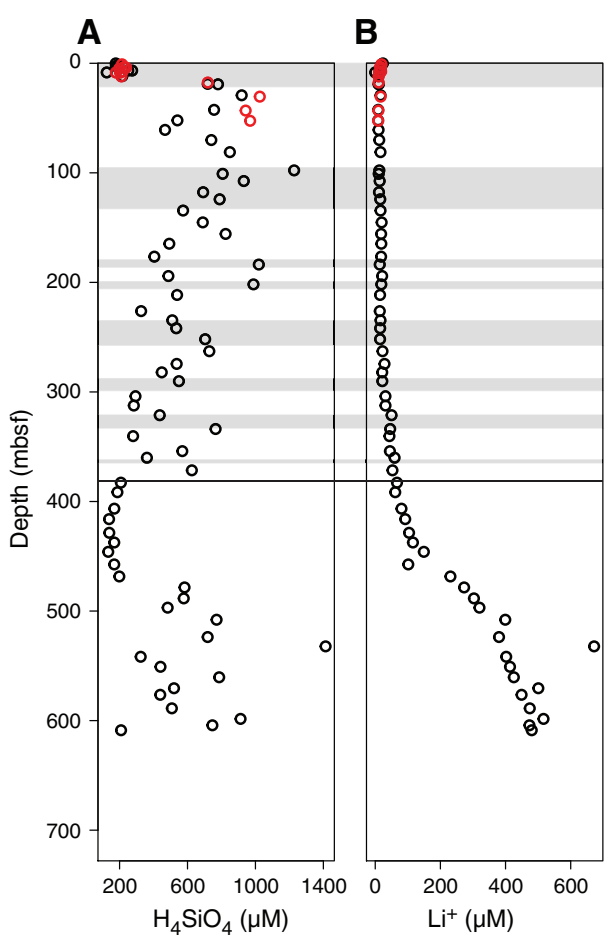

Table T17. Bulk sediment TOC and XRF elemental results, Site M0078. Download table in CSV format.

Figure F24. Solid-phase (A) TC, (B) TOC, and (C) TIC. Black = Hole M0078A, red $=$ Hole M0078B. Gray = marine subunits, black line $=$ Unit 1 (above) $/ 2$ (below) boundary.

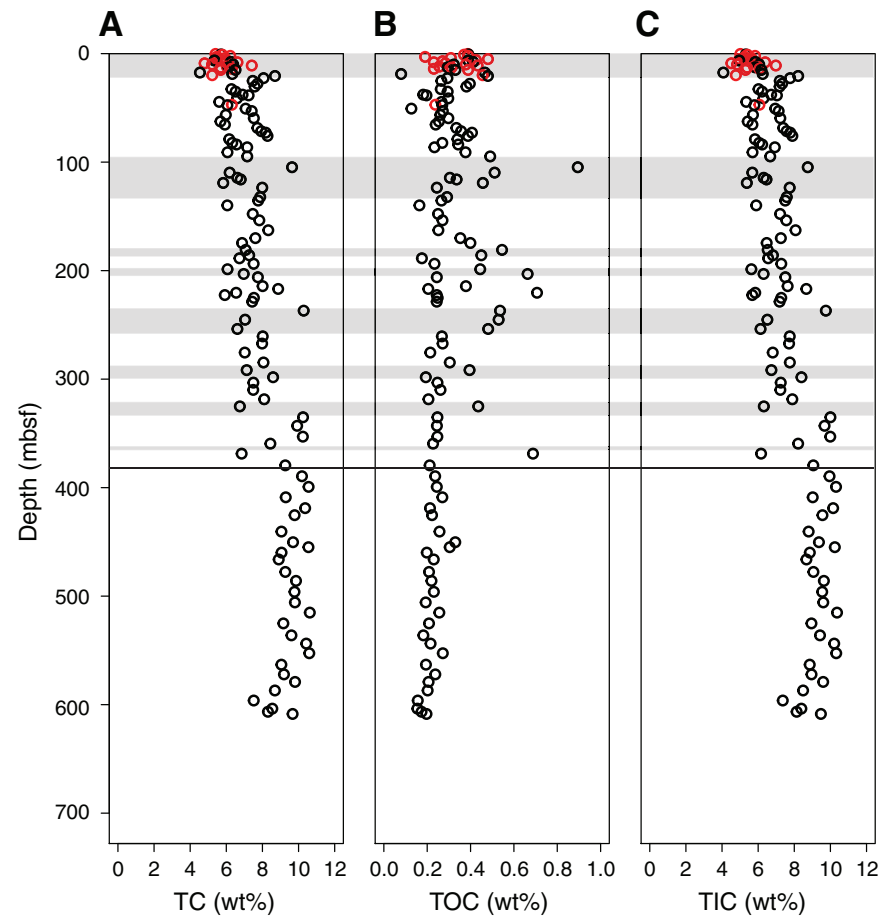


Figure F25. Solid-phase (A) calcium, (B) strontium, and (C) magnesium. Black $=$ Hole M0078A, red $=$ Hole M0078B. Gray $=$ marine subunits, black line $=$ Unit 1 (above)/2 (below) boundary.

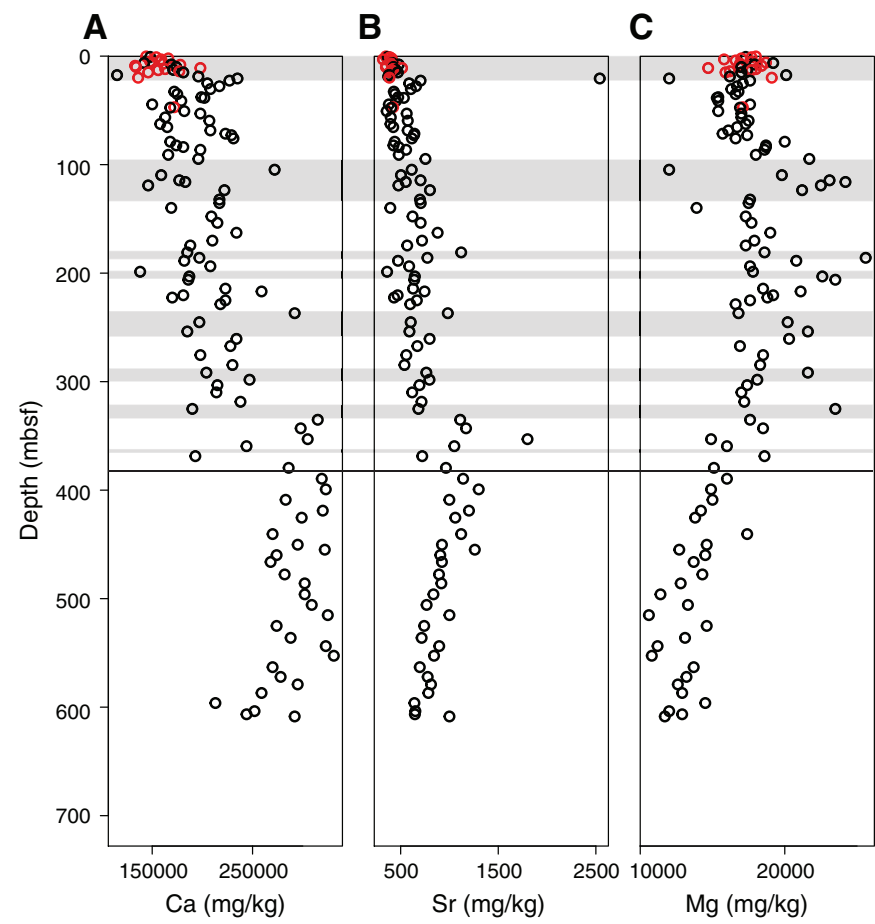

Figure F26. Solid-phase (A) silicon, (B) aluminum, and (C) potassium. Black = Hole M0078A, red $=$ Hole M0078B. Gray $=$ marine subunits, black line $=$ Unit 1 (above)/2 (below) boundary.

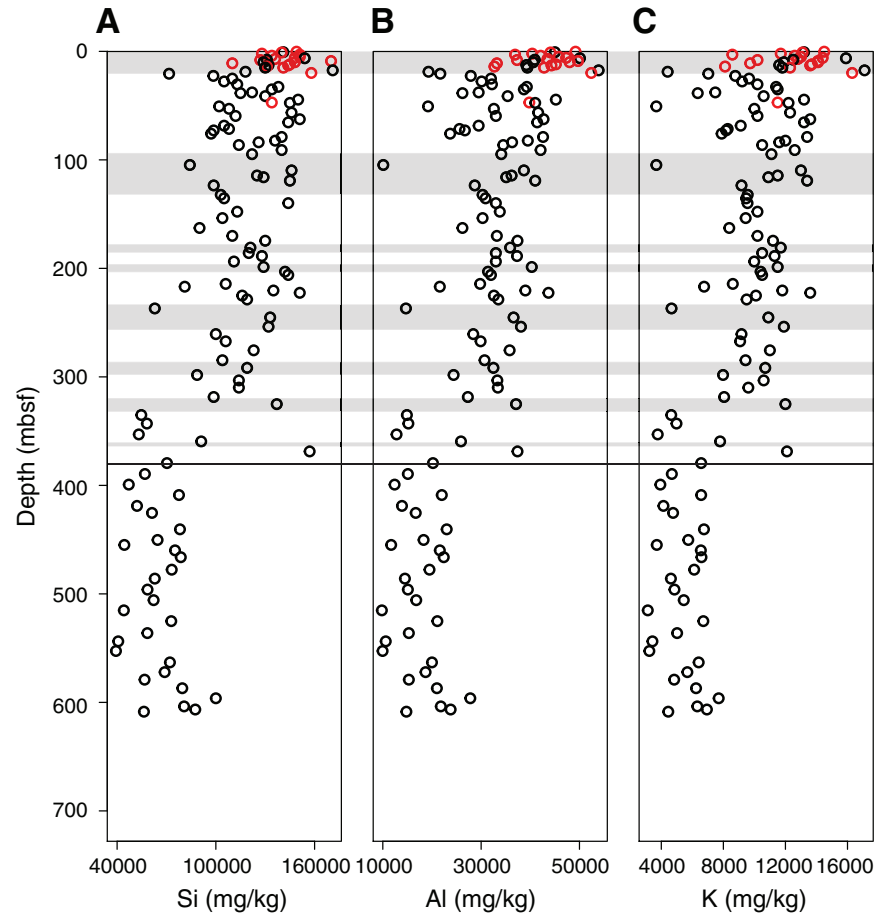

and Mn (Figures F26, F27, F28). The contents of these elements are all lower in Unit 2.

$\mathrm{Mg}$ and $\mathrm{Ni}$, elements that do not show a strong correlation with $\mathrm{Si}$, are also present at lower concentrations below the Unit $1 / 2$
Figure F27. Solid-phase $(A)$ rubidium and (B) zirconium. Black $=$ Hole M0078A, red $=$ Hole M0078B. Gray $=$ marine subunits, black line $=$ Unit 1 (above)/2 (below) boundary.

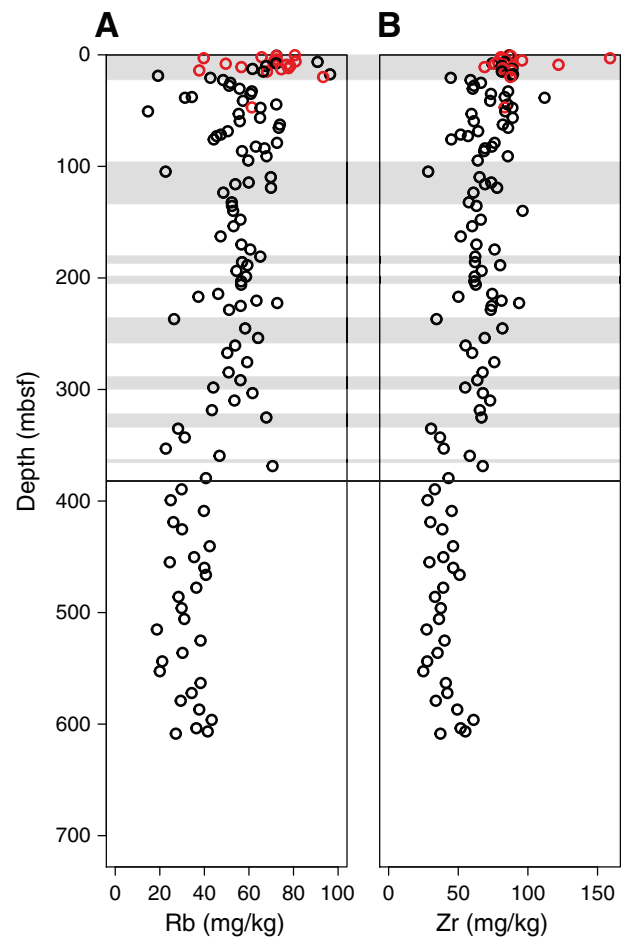

Figure F28. Solid-phase (A) manganese, (B) iron, and (C) nickel. Black $=$ Hole M0078A, red $=$ Hole M0078B. Gray $=$ marine subunits, black line $=$ Unit 1 (above)/2 (below) boundary.

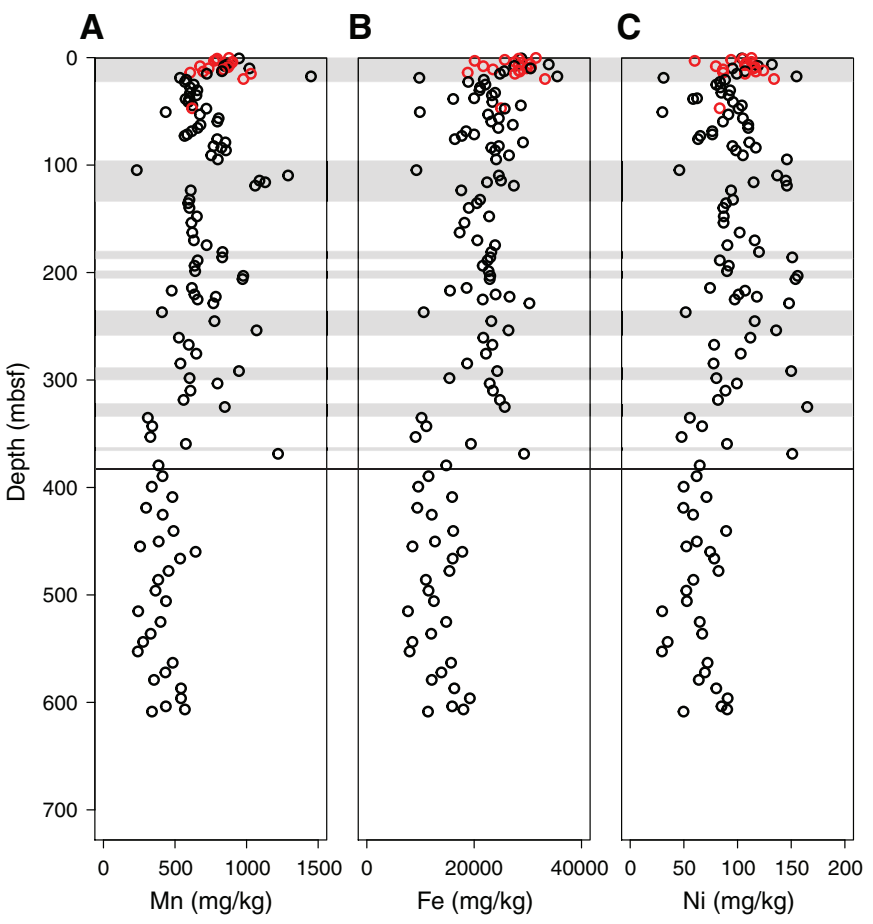

boundary (Figures F25, F28). Sr, which is commonly associated with carbonates, increases below the unit boundary, similar to $\mathrm{Ca}$ (Figure F25). Thus, an overall trend that is evident from the XRF data at Site M0078 is an increase in elements associated with car- 
bonate minerals with depth, especially below the unit boundary, whereas elements normally associated with terrigenous input decrease with depth.

\section{Physical properties}

This section summarizes the preliminary physical properties results from Site M0078. Most data sets were collected at the sampling rates defined in Physical properties in the Expedition 381 methods chapter (McNeill et al., 2019b), except for $P$-wave velocity, thermal conductivity, and shear strength, where the nature of the sediment limited data acquisition (details below). Overall, the data sets collected reflect good correlations with changes in lithology and paleoenvironment, especially magnetic susceptibility, NGR, density, and color reflectance. A synthesis of physical properties for Hole M0078A is presented in Figures F29 and F30.

\section{Shear strength}

Sediment strength for Holes M0078A and M0078B was measured offshore using a handheld penetrometer and a temperature $\mathrm{CPT}$ and onshore using a fall cone and shear vane. Penetrometer and temperature CPT measurements were taken approximately every 20 and $100 \mathrm{~m}$, respectively, whereas fall cone and shear vane measurements were taken one per core section and one per core, respectively.

The derived data using the four different methods differ significantly (Figure F31). Shallower than 400 mbsf, cone resistance derived from offshore handheld penetrometer measurements is consistently larger than other measurements, with a slight increase with depth from 1000 to $\sim 4000 \mathrm{kPa}$ at the base of Hole M0078A. Deeper than $400 \mathrm{mbsf}$, penetrometer values approximately coincide with fall cone shear strength values. CPT measurements provide

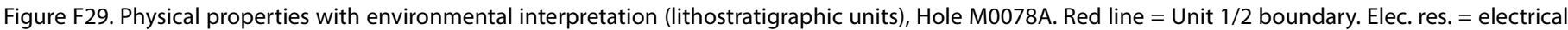
resistivity. $\mathrm{cps}=$ counts per second. Thermal conductivity values are not corrected to in situ conditions.
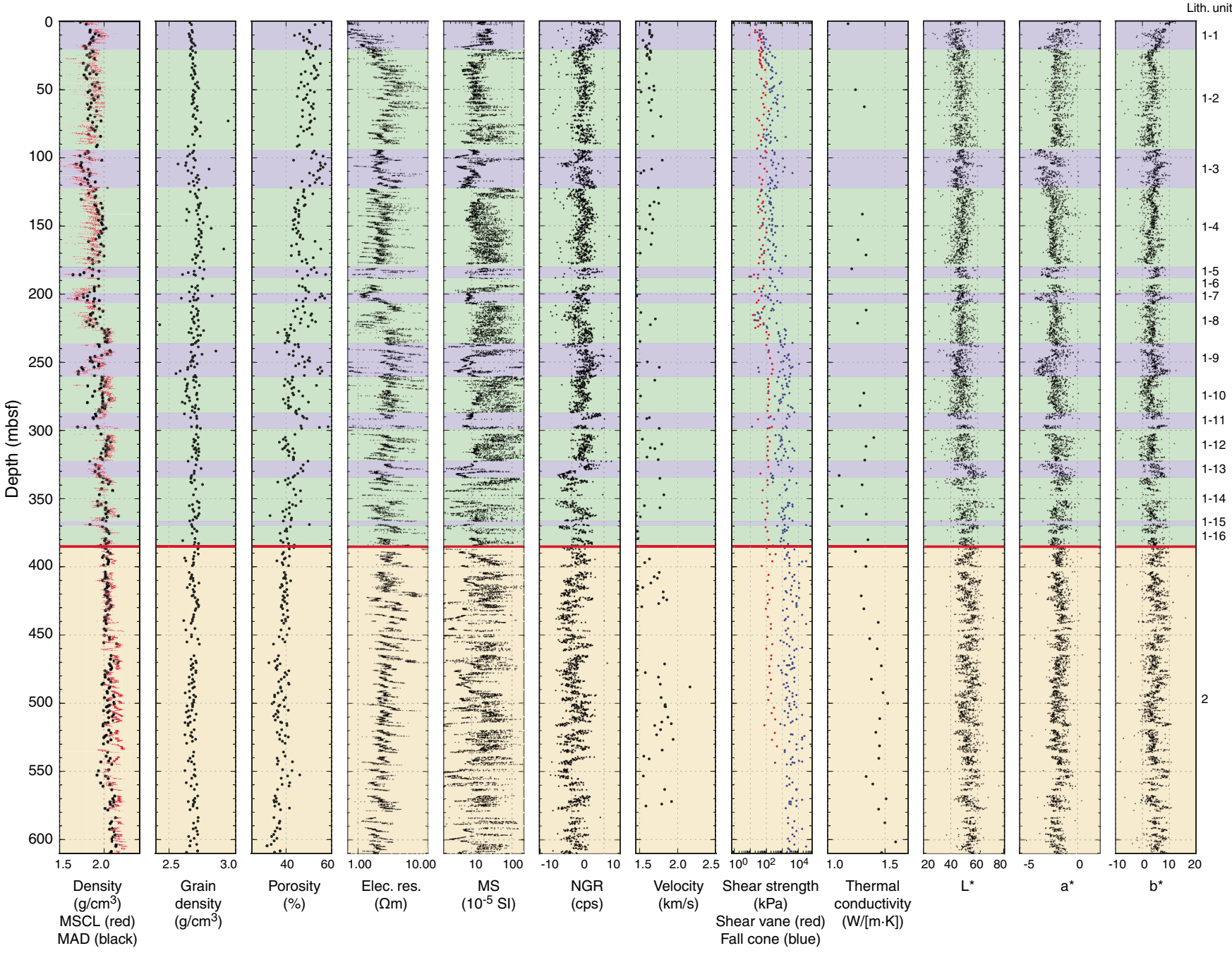
Figure F30. Physical properties with facies associations, Hole M0078A. Red line $=$ Unit 1/2 boundary. Thermal conductivity values are not corrected to in situ conditions. Elec. res. = electrical resistivity.

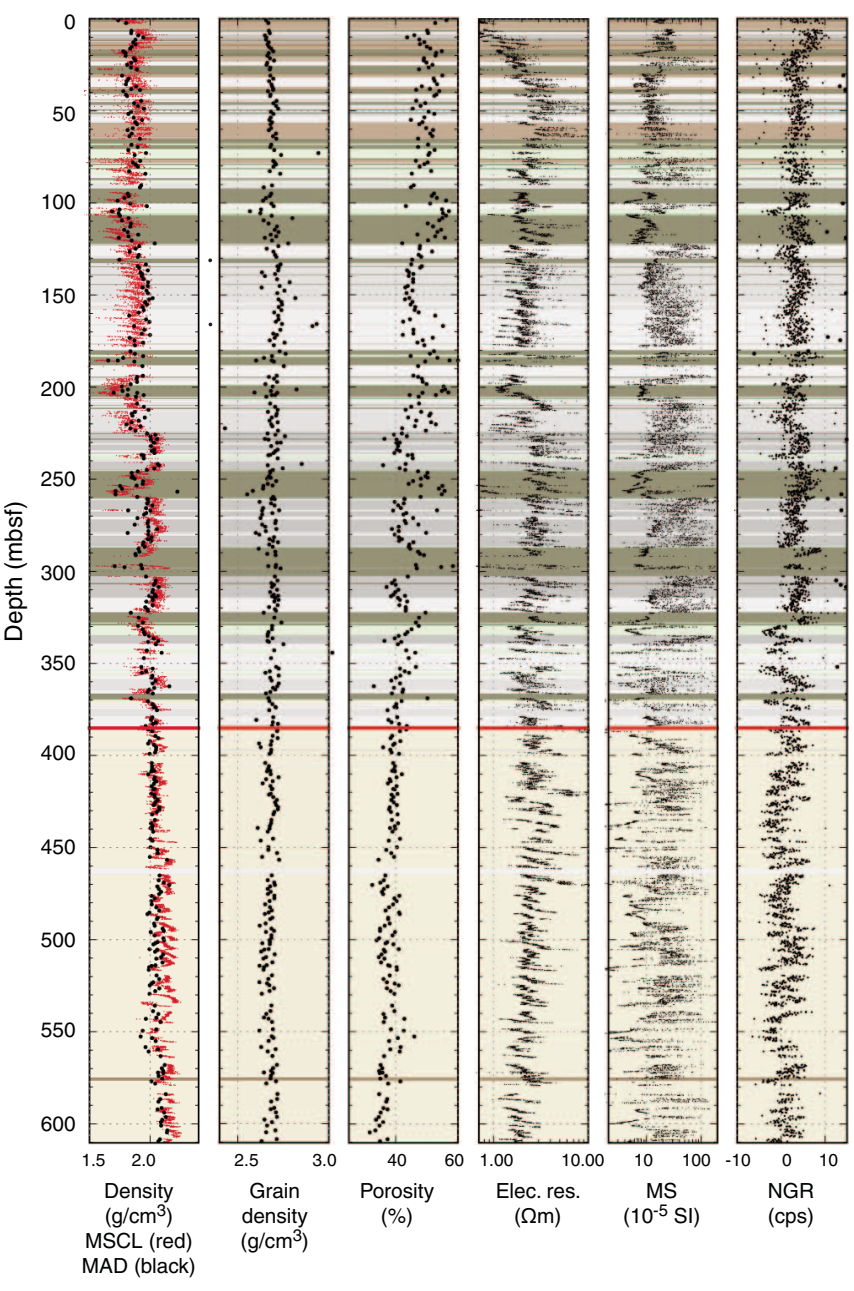

minimum and maximum shear strength values (between the steady and peak state of cone resistivity) that increase from $\sim 460 \mathrm{kPa}$ at $102.64 \mathrm{mbsf}$ to $\sim 700 \mathrm{kPa}$ at $303.03 \mathrm{mbsf}$, similar to fall cone measurements.

Shear strength values derived from fall cone measurements vary over five orders of magnitude (Figure F31). In Hole M0078A, shear strength values increase from 0 to $\sim 30 \mathrm{mbsf}$ and remain relatively constant from $\sim 30$ to $\sim 220$ mbsf. At $\sim 220$ mbsf, shear strength increases sharply. Shear strength measured with the fall cone then increases downhole from $\sim 1000 \mathrm{kPa}$ at $\sim 220 \mathrm{mbsf}$ to $\sim 6000 \mathrm{kPa}$ at the bottom of the hole.

Shear strength values derived from shear vane measurements are much lower than those from fall cone measurements. In the upper 40 mbsf of Hole M0078A, spring stiffness was progressively increased, which had no impact on the measured shear strength. Deeper than 40 mbsf in both Holes M0078A and M0078B, the stiffest spring (4) was used (see Physical properties in the Expedition 381 methods chapter [McNeill et al., 2019b]). In Hole M0078A, shear strength values increase in the upper $30 \mathrm{mbsf}$ and then remain relatively constant to $\sim 225 \mathrm{mbsf}$, where they increase sharply. Deeper than 225 mbsf, shear strength values remain relatively constant to $400 \mathrm{mbsf}$ and then increase downhole. Shear vane measurements were stopped at $526.88 \mathrm{mbsf}$ (Section 156R-2), where

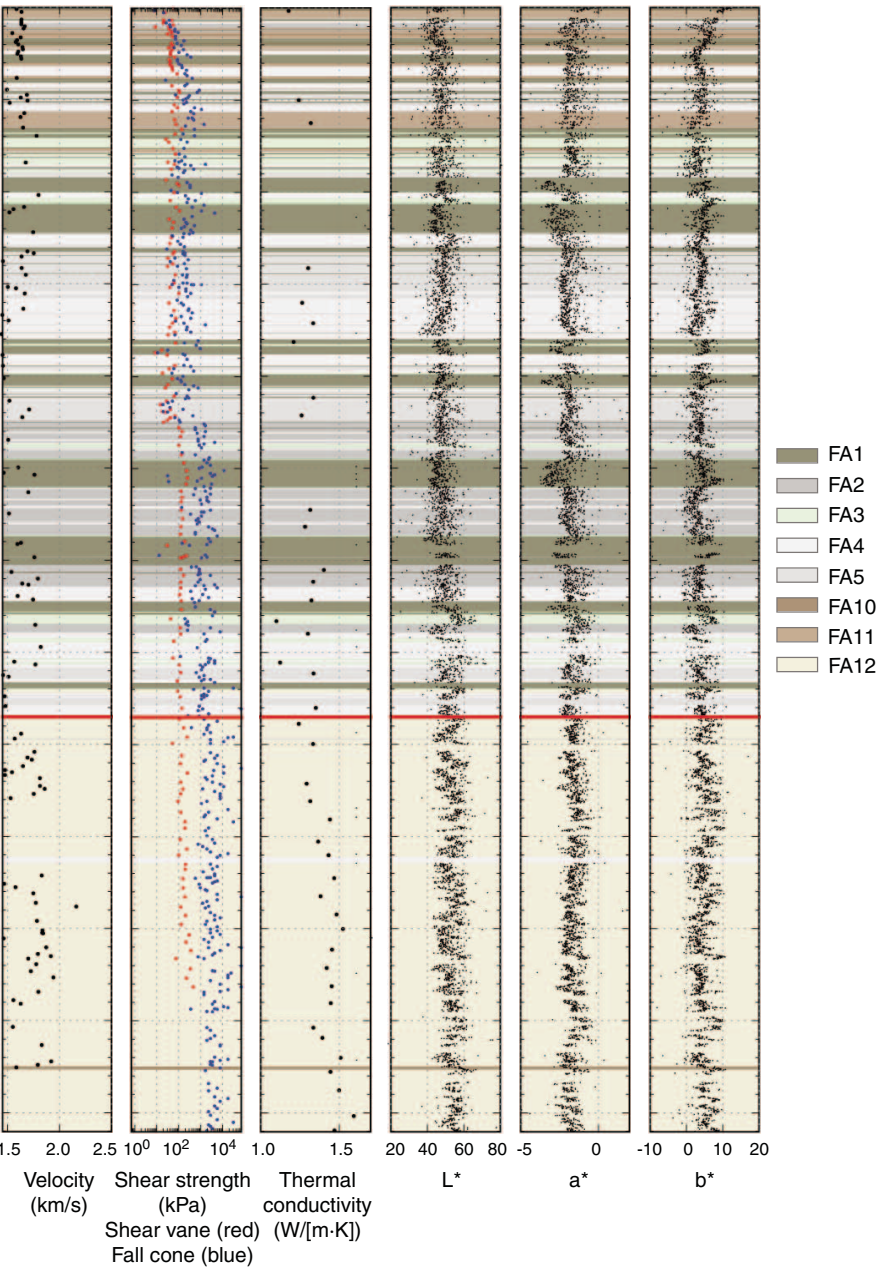

sediment strength exceeded the applied force capacity of the shear vane apparatus.

Shear strength values are lower in Hole M0078B than in Hole M0078A (Figure F31), although they exhibit a similar relationship between fall cone, shear vane, and penetrometer measurements and the same steady increase with depth.

The high cone resistance values $(\sim 1000 \mathrm{kPa})$ recorded by the handheld penetrometer may be misleading, especially in the shallower sections of Holes M0078A and M0078B, because the values are similar to the shear strength expected for extremely weak to very weak rocks. In all these sections, the shear vane could easily be inserted; hence, the sediment can be described as no stronger than stiff clay. Therefore, the maximum expected shear strength is $\sim 500$ $\mathrm{kPa}$.

Shear vane measurements provide more realistic strength values than fall cone measurements. However, fall cone and shear vane measurements (taken at spots $<10 \mathrm{~cm}$ apart) are correlated (Figure F32), indicating that fall cone measurements do provide a reliable indication of relative variations in shear strength.

Despite the different ranges in shear strength values that the three measurements provide, they all follow similar patterns and indicate a general trend of increasing sediment strength with depth. The most abrupt increase occurs at approximately $228 \mathrm{mbsf}$ (Sec- 
Figure F31. Shear strength measurements, Holes M0078A and M0078B.

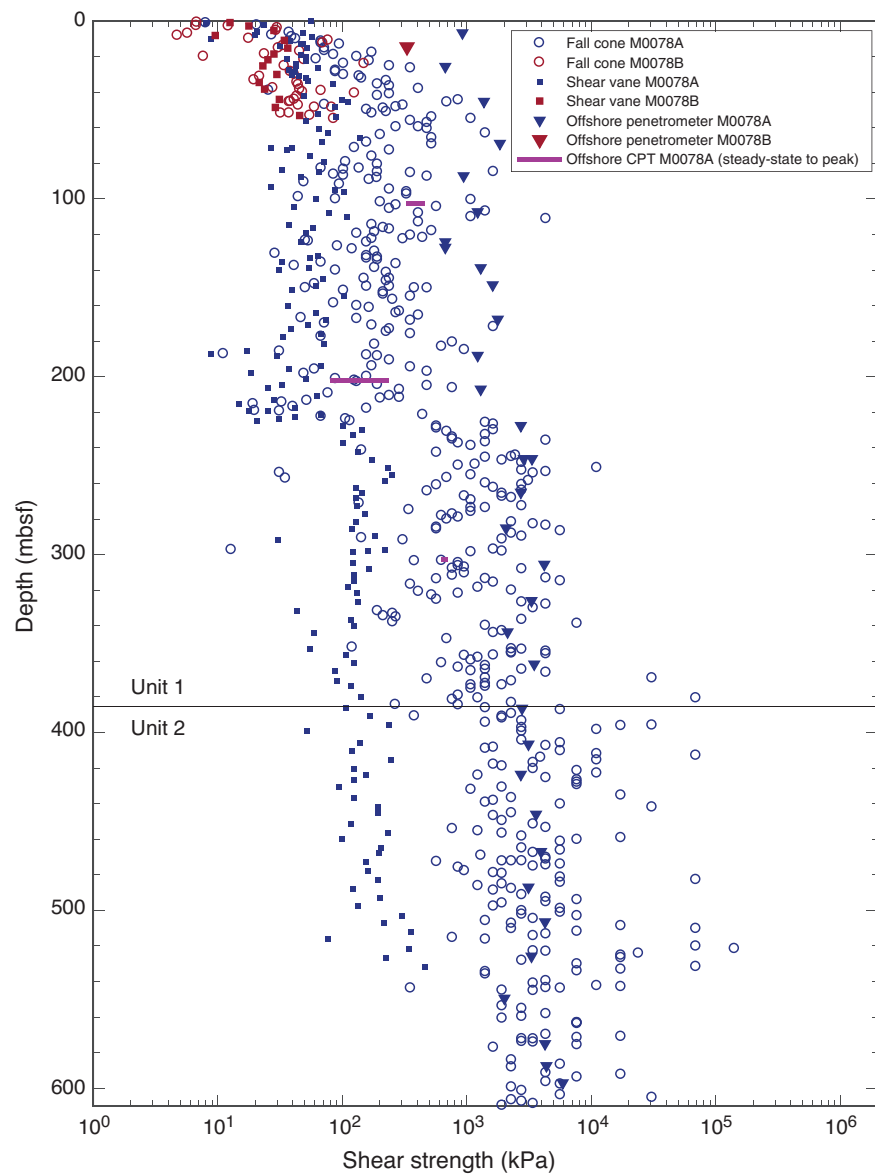

Figure F32. Fall cone and shear vane data correlations, Holes M0078A and M0078B.

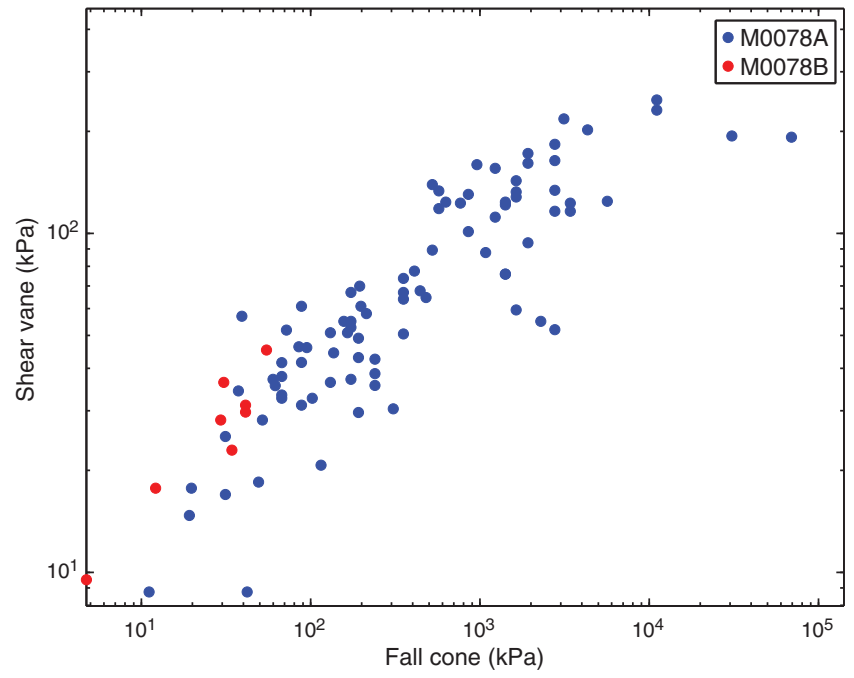

tion 381-M0078A-85R-2) and was observed in both fall cone and shear vane measurements (Figure F31). This strength increase, as well as an increase in density and electrical resistivity at a similar depth (Figure F29), coincides with both a change in coring method and with lithologic changes marked by a change in facies association. The coincidence with the change from FA5 to FA2 suggests an abrupt transition to more consolidated sediment driven by lithology change.

\section{Natural gamma radiation}

Overall low NGR values at Site M0078 indicate that K, Th, and $\mathrm{U}$ concentrations are depleted in the mud-dominated cores (Figures F29, F30). Note that the negative values result from the removal of the background during data processing, which was determined at the beginning of the expedition. Despite these negative values, gamma ray data acquired during downhole logging at other sites compare well with trends measured in cores from the same holes, suggesting these data faithfully capture NGR trends in the hole.

A significant change in the NGR trend occurs at $330 \mathrm{mbsf}, 55 \mathrm{~m}$ above the Unit $1 / 2$ boundary (Figure F33). The section shallower than 330 mbsf has on average distinctly higher values than the section deeper than 330 mbsf (Figure F34). Shallower than 330 mbsf, NGR values average 3.61 counts/s with a minimum of -6.44 counts/s and a maximum of 15.28 counts/s. NGR values in the marine intervals shallower than 330 mbsf often appear to be high (mean $=3.54$ counts $/ \mathrm{s})$ relative to values in the isolated $/ \mathrm{semi}$-isolated intervals (mean $=0.89$ counts $/ \mathrm{s}$ ).

Deeper than 330 mbsf, NGR values average 0.92 counts/s with a minimum of -6.51 counts/s and a maximum of 14.71 counts/s (Figure F34). Variations in NGR deeper than 330 mbsf appear to occur at the scale length of $\sim 10 \mathrm{~m}$ (Figure F33). Lithostratigraphic Unit 2 is associated with FA12 (light gray to gray homogeneous mud), has abundant bioturbation, and may be responsible for the variability in NGR values.

At 104 mbsf, a low in NGR occurs that is associated with FA3 (light gray/white thin laminations [calcite/aragonite] alternating with mud/silt beds). XRD results confirm that the total concentration of muscovite, K-feldspar, smectite, illite, and kaolinite in this layer is $\sim 5 \%$, whereas this concentration is typically $>10 \%$ in the uppermost $200 \mathrm{~m}$ of the hole. At $330 \mathrm{mbsf}$, a low NGR value occurs in a section that is also associated with FA3 (Figure F33).

\section{Magnetic susceptibility}

Magnetic susceptibility appears to be a good indicator for lithology and basin environment at Site M0078 (Figure F29). In Unit 1, magnetic susceptibility values range from $\sim 0$ to $\sim 200 \times 10^{-5}$ SI. One of the distinct features of magnetic susceptibility is that it decreases abruptly in marine intervals/subunits (mostly associated with FA1; Figure F30), averaging $20 \times 10^{-5} \mathrm{SI}$, and is higher but scattered in Unit 1 isolated/semi-isolated intervals/subunits (Figure F35). The scattered magnetic susceptibility behavior in isolated/semi-isolated intervals may be due to change in the terrigenous input during sedimentation, fluctuations in the quantity of fine detrital particles, and/or diagenetic processes. The thickness of lower value intervals associated with marine subunits increases upsection. Going downhole in Unit 1, sharp drops are seen in the magnetic susceptibility data at 98, 200, 238, and $253 \mathrm{mbsf}$, where the facies association changed from FA1 (homogeneous mud) to FA4 (laminated greenish gray to gray mud).

In Unit 2, 10 m thick intervals with values typically below $10 \times$ $10^{-5} \mathrm{SI}$ alternate with $10-20 \mathrm{~m}$ thick intervals, similar to NGR (Figure F33), with higher values ranging from $\sim 10 \times 10^{-5}$ to $\sim 200 \times 10^{-5}$ SI. 
Figure F33. MSCL NGR and magnetic susceptibility trends from 300 to 500 mbsf, Hole M0078A. Left two panels include environmental interpretation (Unit 1 subunits: blue $=$ marine, green $=$ isolated $/$ semi-isolated; yellow $=$ Unit 2, red line $=$ Unit $1 / 2$ boundary); right two panels include facies associations $($ white $=$ no recovery).
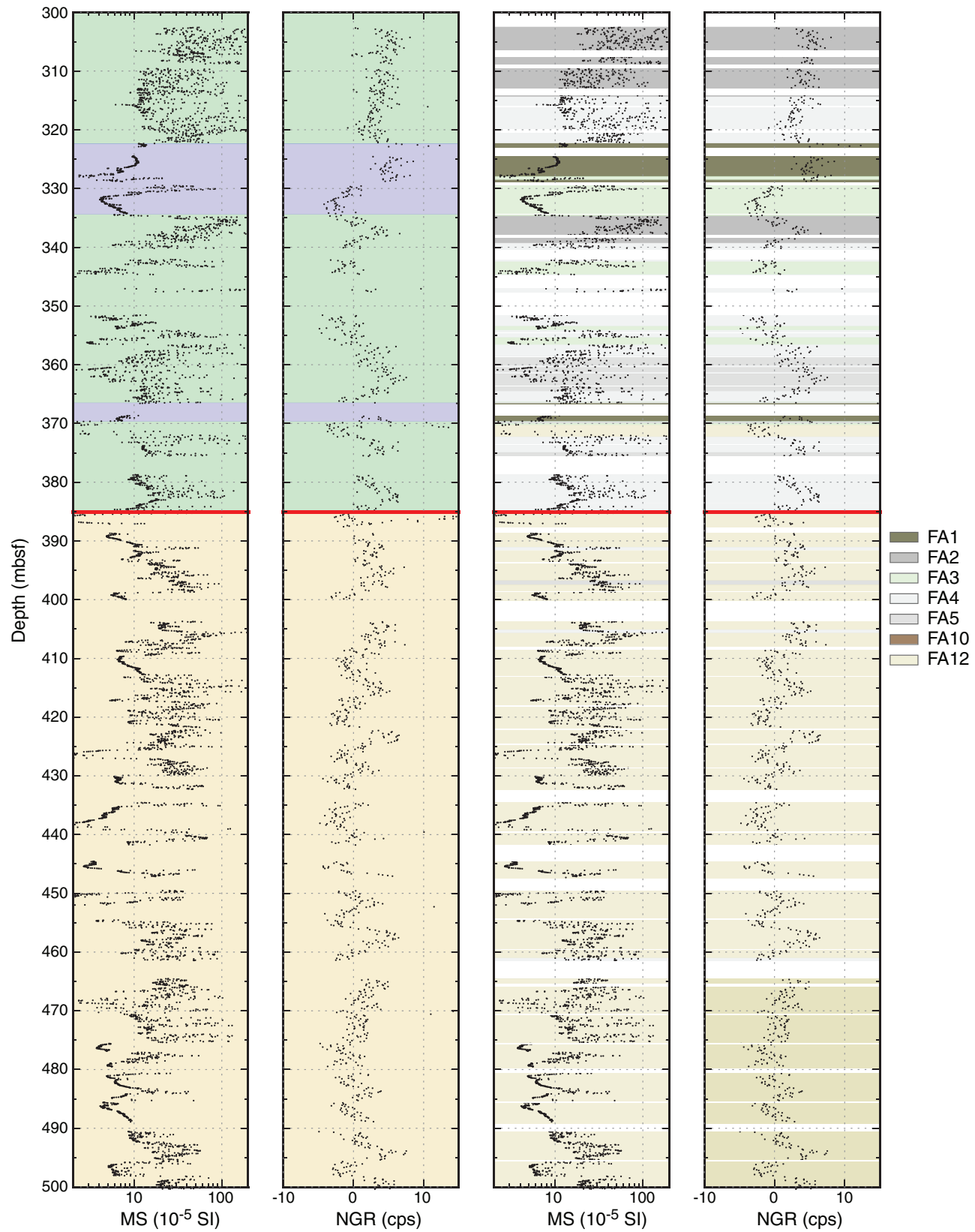

Magnetic susceptibility values sometimes drop below 0 SI (Figure F35). These values reflect sensor drift on some sections and are likely closer to 0 .

\section{$P$-wave velocity}

$P$-wave velocity measurements were collected offshore using a Geotek MSCL. Onshore, they were collected on split cores using the MSCL track and on discrete samples using a Geotek $P$-wave logger for discrete samples (see Physical properties in the Expedition 381 methods chapter [McNeill et al., 2019b]).

Core quality (coring disturbances, the variable fill space between the sediment and the core liner, voids between and in the sediment layers, and/or the presence/absence of fluids in the core liner)

strongly affected $P$-wave velocity measurements performed with the MSCL both onshore and offshore. Realistic values were only collected offshore in the upper few meters for both Holes M0078A and $\mathrm{M} 0078 \mathrm{~B}$ (0-12 and 0-10 mbsf, respectively), and they range between 1500 and $1515 \mathrm{~m} / \mathrm{s}$ (Figure F36). P-wave velocity measurements on discrete samples were also strongly affected by the unconsolidated nature of the core samples in the upper part of Holes M0078A and M0078B. Downhole in Hole M0078A, the increase in stiffness led to more brittle behavior, and cracks in the samples likely affected $P$-wave signals, decreasing the reliability of velocity measurements. Realistic $P$-wave velocity values are between 1500 and $2161 \mathrm{~m} / \mathrm{s}$ in Hole M0078A and between 1500 and $1769 \mathrm{~m} / \mathrm{s}$ in Hole M0078B. In Hole M0078A, velocity values in- 
Figure F34. MSCL NGR box and whisker plots grouped by subunits, Expedition 381. Top and bottom of boxes correspond to 1st and 3rd quartiles, solid line in middle of box shows the median, dashed line shows the mean. Ends of whiskers indicate minimum and maximum values. $\mathrm{l} / \mathrm{SI}=\mathrm{isolated} / \mathrm{semi}-\mathrm{isolated}$
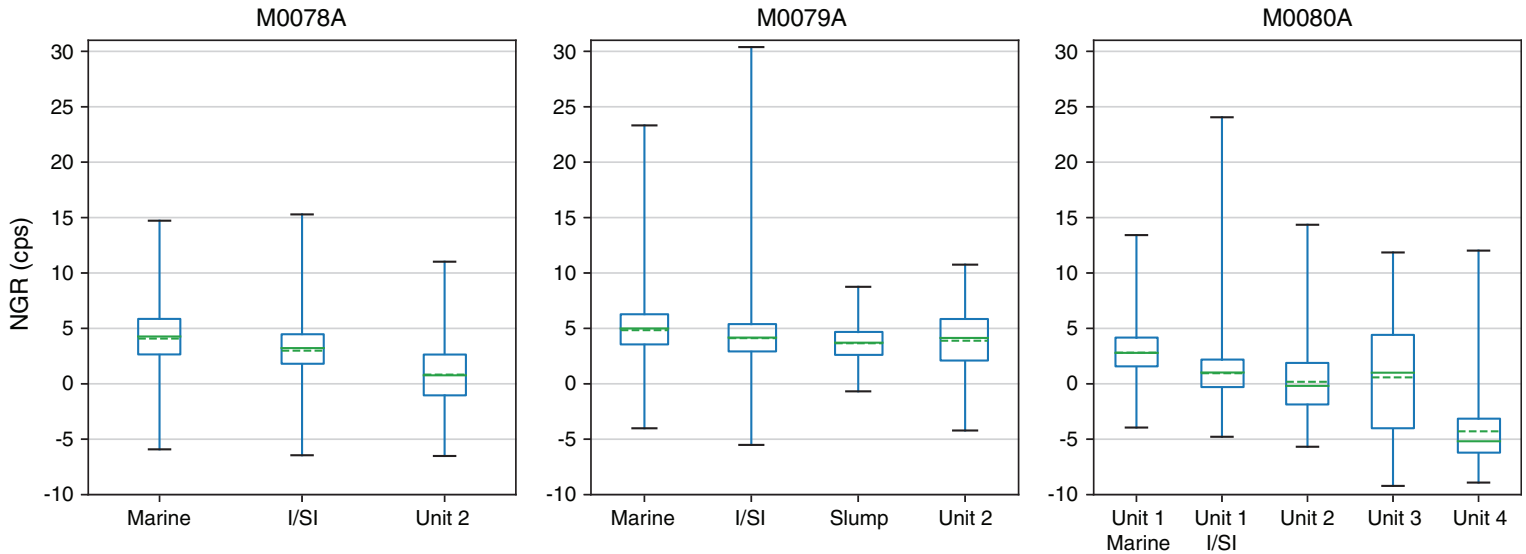

Figure F35. MSCL magnetic susceptibility box and whisker plots grouped by subunits, Expedition 381. Top and bottom of boxes correspond to 1 st and 3rd quartiles, solid line in middle of box shows the median, dashed line shows the mean. Ends of whiskers indicate minimum and maximum values. $\mathrm{I} / \mathrm{SI}=\mathrm{iso}-$ lated/semi-isolated.
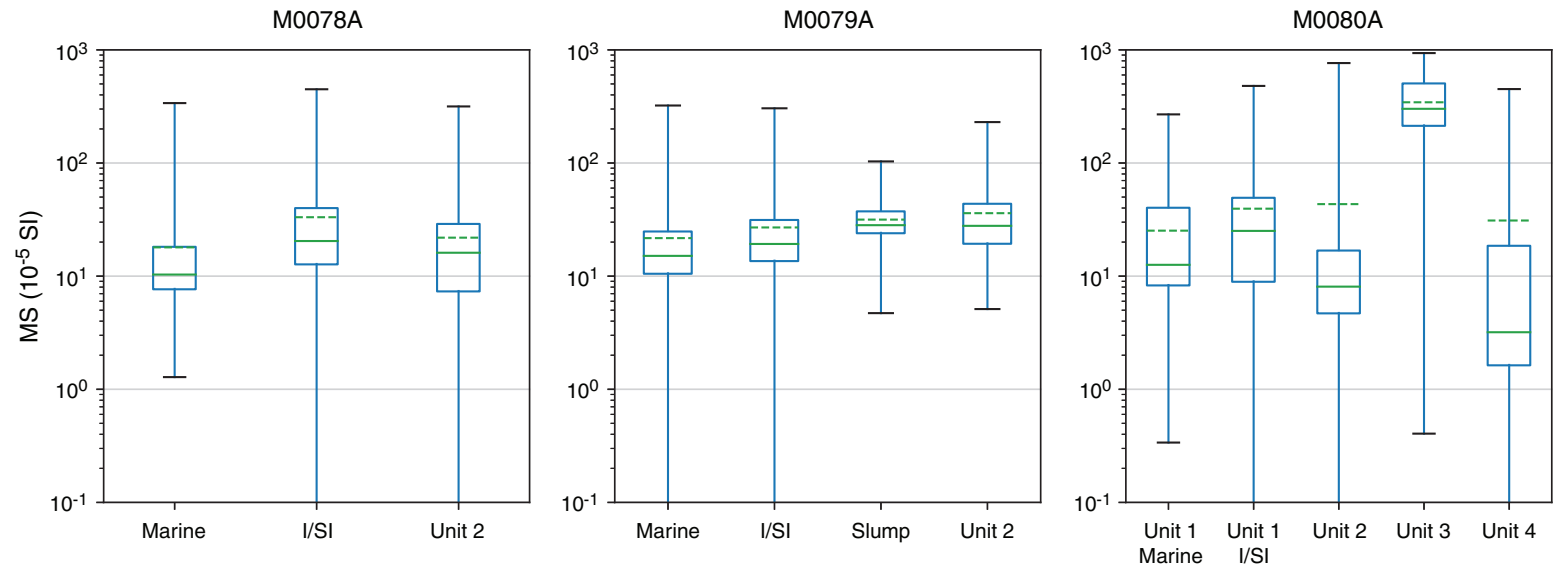

crease slightly with depth. However, these values are still smaller than what would be expected at 600 mbsf (see Core-log-seismic integration for velocity discussion). Low velocity values collected from discrete samples might also be due to the material not being in situ. $P$-wave velocity values are sparsely distributed with depth, so it was not possible to identify any potential downhole trends.

\section{Density}

Offshore, density data (bulk density) were obtained using the gamma ray attenuation (GRA) technique on the MSCL, whereas onshore, density data (bulk and grain density) were obtained using the moisture and density (MAD) analysis technique on discrete samples.

MSCL bulk density values range from 1 to $2.26 \mathrm{~g} / \mathrm{cm}^{3}$ with $~ 96 \%$ above $1.70 \mathrm{~g} / \mathrm{cm}^{3}$ (Figure F29). The results show a general increase in density with depth in Hole M0078A punctuated by a few intervals with drops in density that are followed by a return to the previous average values. The average MSCL density value is $1.97 \mathrm{~g} / \mathrm{cm}^{3}$. Two notable increases in density occur at approximately 225 and 450 mbsf. The increase at 225 mbsf is relatively better defined and appears to occur at the same depth as an increase in shear strength. The average density is $1.84 \mathrm{~g} / \mathrm{cm}^{3}$ from 0 to $225 \mathrm{mbsf}, 2.0 \mathrm{~g} / \mathrm{cm}^{3}$ from 225 to $450 \mathrm{mbsf}$, and $2.12 \mathrm{~g} / \mathrm{cm}^{3}$ from 450 to $610 \mathrm{mbsf}$. Re- duced density correlates with (parts of) the marine intervals/subunits (e.g., 195-205, 240-260, 290-300, 322-335, and 370 mbsf).

Discrete bulk density values and trends from the MAD analysis match well with the MSCL data, ranging from 1.41 to $2.50 \mathrm{~g} / \mathrm{cm}^{3}$ with $98 \%$ above $1.70 \mathrm{~g} / \mathrm{cm}^{3}$, and generally increase with depth. The average density value from the MAD analysis is $1.96 \mathrm{~g} / \mathrm{cm}^{3}$. Notable increases in density occur at approximately 136, 227, and 455 mbsf. The largest decreases in discrete bulk density are associated with the marine subunits, as is the case with MSCL GRA bulk density (in the same intervals noted above).

Sediment grain density values calculated from the MAD analysis range from 1.88 to $3.14 \mathrm{~g} / \mathrm{cm}^{3}$ with an average of $2.6 \mathrm{~g} / \mathrm{cm}^{3}$, and $93 \%$ of the values are between 2.6 and $2.8 \mathrm{~g} / \mathrm{cm}^{3}$. These grain density values are between pure sandstone and pure limestone (Kennedy, 2015). Grain density generally increases with increasing bulk density and decreasing porosity. As with bulk density, low grain density correlates with some marine intervals/subunits (Figure F29).

\section{Porosity}

Porosity values calculated from the MAD analysis range from $14 \%$ to $65 \%$ with an average of $43 \%$. Average porosity values in Units 1 and 2 are $46 \%$ and $38 \%$, respectively. Porosity decreases with depth from an average of $50 \%$ in the uppermost $10 \mathrm{~m}$ of the hole to 
Figure F36. $P$-wave velocity data, Holes M0078A and M0078B.

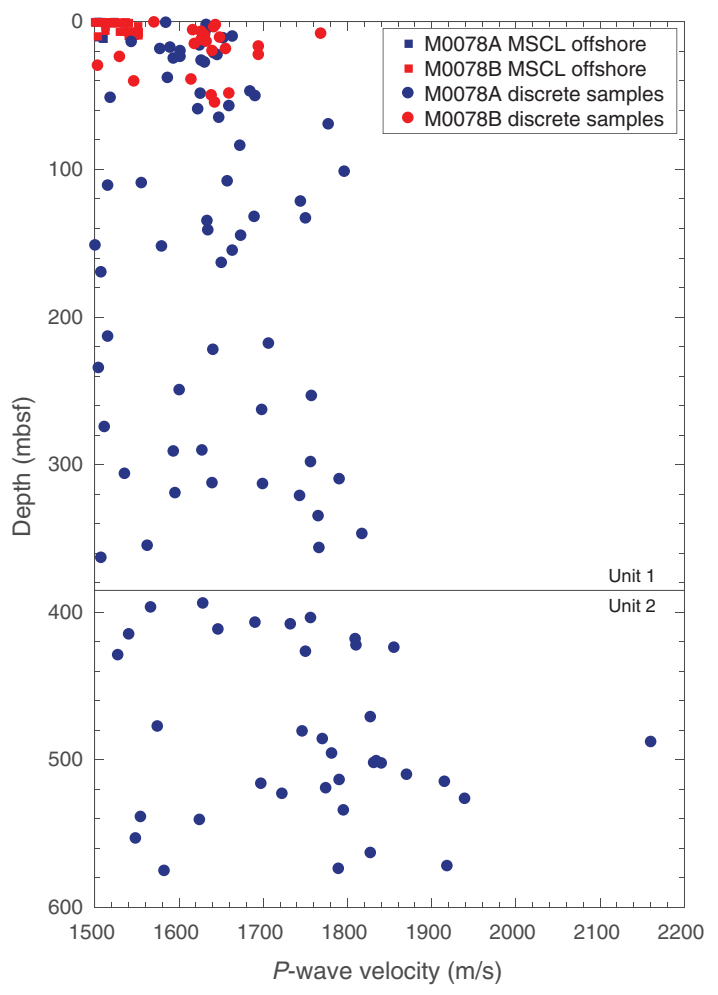

an average of $32 \%$ in the lowermost $10 \mathrm{~m}$ of the hole. Notable intervals of increased porosity with depth (e.g., 195-205, 250, and $\sim 322-335 \mathrm{mbsf}$ ) correspond to noted intervals of decreased density that are associated with interpreted marine environments. Porosity decreases at $\sim 224$ mbsf, which coincides with an increase in density, resistivity, and shear strength and may be associated with a coring method change or increased consolidation linked to lithologic change, coincident with a facies association change (see Shear strength; Figures F29, F30). A further decrease occurs in Unit 2 at $\sim 450 \mathrm{mbsf}$, also coincident with increased density. These two changes divide the borehole into three sections: 0-224 mbsf (average porosity $=48 \%$ ), 224-450 mbsf (average porosity $=42 \%$ ), and $450-610 \mathrm{mbsf}$ (average porosity $=37 \%$ ).

\section{Resistivity}

For Site M0078, electrical resistivity was measured offshore using the MSCL. The resistivity measured is low, ranging from 0.1 to $30 \Omega \mathrm{m}$ (Figure F37). The mean resistivity is $2.64 \Omega \mathrm{m}$ with a standard deviation of $1.45 \Omega \mathrm{m}$.

In each core, resistivity tends to increase from the top to the base, with a corresponding increase in density, especially in Unit 2 (Figure F38C, F38D). This tendency suggests an effect of drillinginduced disturbance. Electrical resistivity correlates well between Holes M0078B and M0078A, indicating reduced variations related to drilling disturbance in the shallow section of both holes (Figure F38).

Low resistivity values are recorded in the shallower part of the hole, with an exponential increase with depth to $50 \mathrm{mbsf}$ (note log scale on Figures F29 and F38). The mean resistivity value then remains almost constant to $380 \mathrm{mbsf}$, with values of $1-3 \Omega \mathrm{m}$ and larger variability in nonmarine subunits. Deeper than $400 \mathrm{mbsf}$, electrical resistivity decreases from 3 to $1 \Omega \mathrm{m}$ (Figure F29). This de- crease, which is related to a decrease in porosity, suggests an increase in fluid conductivity at the bottom of the hole.

The low resistivity values recorded at Site M0078 are compatible with the values derived from the Archie equation for a porosity in the range of $35 \%-50 \%$ and a fluid conductivity equal to that of seawater.

\section{Thermal conductivity}

Thermal conductivity values range from 1.09 to $1.59 \mathrm{~W} /(\mathrm{m} \cdot \mathrm{K})$ with an average of $1.35 \mathrm{~W} /(\mathrm{m} \cdot \mathrm{K})$. Thermal conductivity averages $1.27 \mathrm{~W} /(\mathrm{m} \cdot \mathrm{K})$ in Unit 1 and $1.42 \mathrm{~W} /(\mathrm{m} \cdot \mathrm{K})$ in the underlying Unit 2. Increases in thermal conductivity occur at 62.5 and $440 \mathrm{mbsf}$, dividing the data downhole into three distinct sections. The average thermal conductivity is $1.21 \mathrm{~W} /(\mathrm{m} \cdot \mathrm{K})$ from 0 to $62.5 \mathrm{mbsf}, 1.29$ $\mathrm{W} /(\mathrm{m} \cdot \mathrm{K})$ from 62.5 to $440 \mathrm{mbsf}$, and $1.45 \mathrm{~W} /(\mathrm{m} \cdot \mathrm{K})$ from 440 to 610 mbsf. Thermal conductivity is lowest in intervals correlating with FA5 (light gray to white submillimeter laminations of calcite or aragonite alternating with mud-silt beds; see Lithostratigraphy). Relatively higher thermal conductivity values consistently occur in Unit 2. Laboratory values were corrected to in situ conditions because thermal conductivity is affected by temperature and pressure; the in situ thermal conductivity values range from 1.14 to 1.71 $\mathrm{W} /(\mathrm{m} \cdot \mathrm{K})$ and show a similar trend to the laboratory measurements (Figures F29, F39C). The correction to in situ conditions was done following Hyndman et al. (1974) (see Physical properties in the Expedition 381 methods chapter [McNeill et al., 2019b]).

\section{Formation temperature and heat flow}

Temperature measurements were collected offshore at four depths and plotted against depth to estimate the geothermal gradient (Figure F39C). The geothermal gradient is approximately $8^{\circ} \mathrm{C} / \mathrm{km}$, which like the temperature values is very low.

The temperature data were used with thermal conductivity to estimate heat flow using the Bullard method, which plots the thermal resistance against temperature (Figure F39B) and calculates heat flow from the slope of the best fitting line (see Physical properties in the Expedition 381 methods chapter [McNeill et al., $2019 \mathrm{~b}])$. The calculated heat flow is $\sim 11 \mathrm{~mW} / \mathrm{m}^{2}$.

The temperature at the seafloor can be determined from the intercept of a plot of temperature against depth using the three temperature measurements at 102.8, 202.8, and 303 mbsf (Figure F39A). The seafloor temperature estimated from temperature CPT data is $13.31^{\circ} \mathrm{C}$, which is lower than the $13.75^{\circ} \mathrm{C}$ measured. Using this seafloor temperature of $13.31^{\circ} \mathrm{C}$, the calculated geothermal gradient is $9^{\circ} \mathrm{C} / \mathrm{km}$ and the heat flow from the Bullard plot is $\sim 12$ $\mathrm{mW} / \mathrm{m}^{2}$.

\section{Color reflectance}

The mean color reflectance values \pm standard deviations and minimum/maximum values of all depths in Hole M0078A are (Figure F40) $50 \pm 7$ and $0 / 77$, respectively, for $L^{*},-1.8 \pm 0.9$ and $-10.9 / 0.7$, respectively, for $\mathrm{a}^{*}$, and $4.0 \pm 3.0$ and $-20 / 29$, respectively, for $b^{*}$. The main change in color reflectance occurs around 330-350 mbsf. Shallower than 330-350 mbsf, $\mathrm{L}^{*}, \mathrm{a}^{*}$, and $\mathrm{b}^{*}$ values average 48 , -2.0 , and 3.4, respectively, and deeper than 330-350 mbsf, they average $53,-1.7$, and 4.6 , respectively. This division occurs above the Unit $1 / 2$ boundary at 385.14 mbsf (Figures F29, F30).

Some color reflectance values deviate from the mean values for Hole M0078A when they occur in specific sedimentary facies associations (Figure F30). Most notable changes in color reflectance values occur mainly in two sedimentary facies associations. FA1 
Figure F37. MSCL electrical resistivity box and whisker plots grouped by subunits, Expedition 381. Top and bottom of boxes correspond to 1st and 3rd quartiles, solid line in middle of box shows the median, dashed line shows the mean. Ends of whiskers indicate minimum and maximum values. $\mathrm{l} / \mathrm{SI}=\mathrm{isolated} / \mathrm{semi}$ isolated.
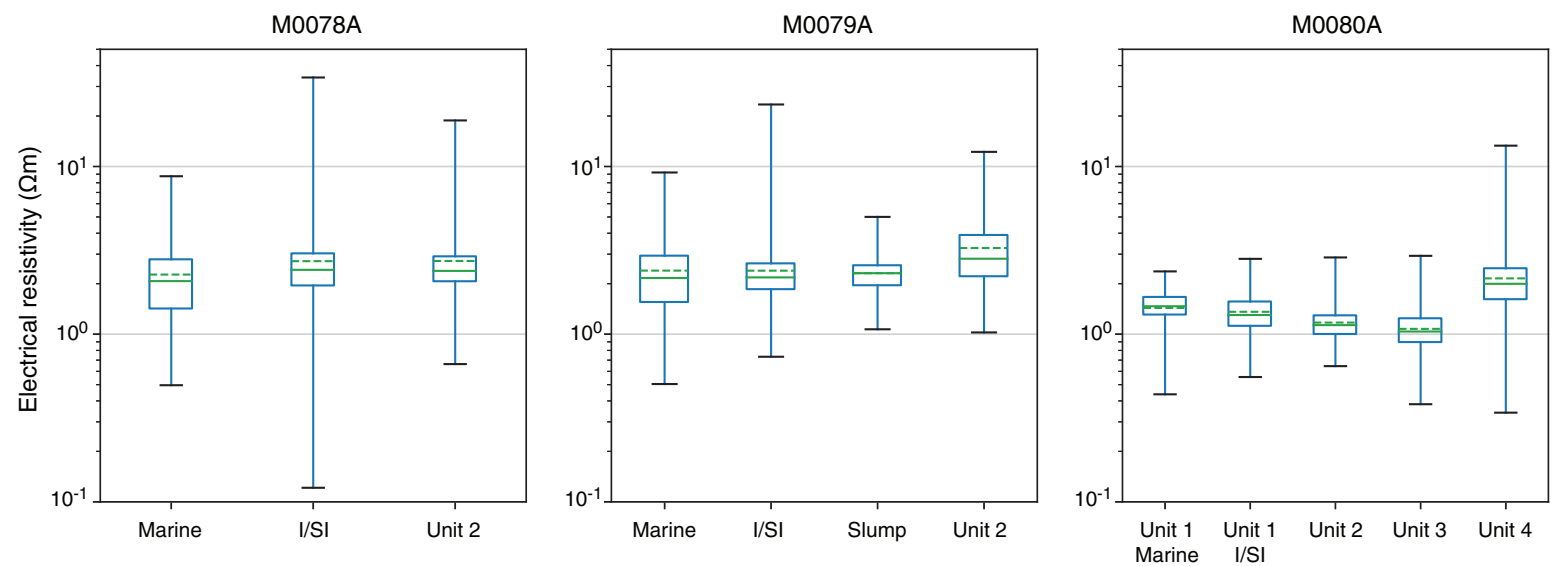

Figure F38. Resistivity and density trends observed in cores, Holes M0078A and M0078B.

\section{A}
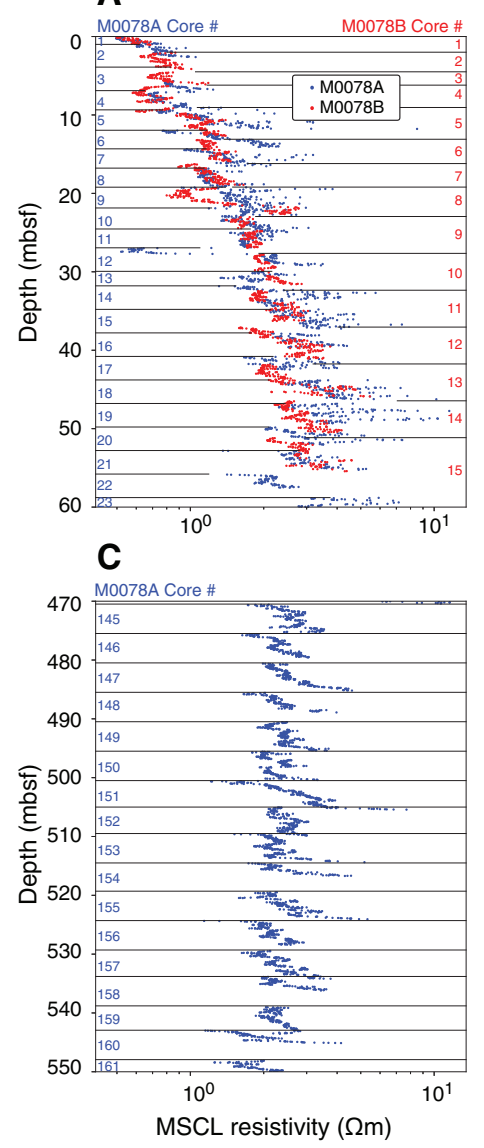

\section{B}

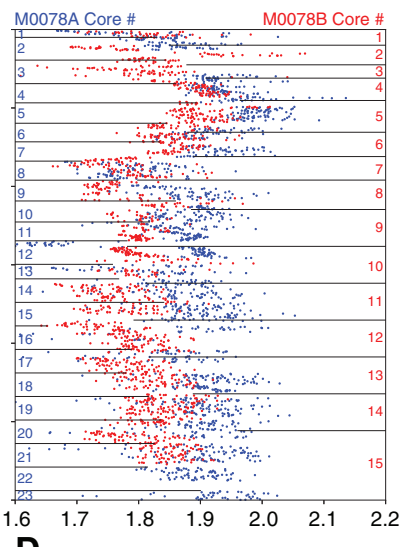

D
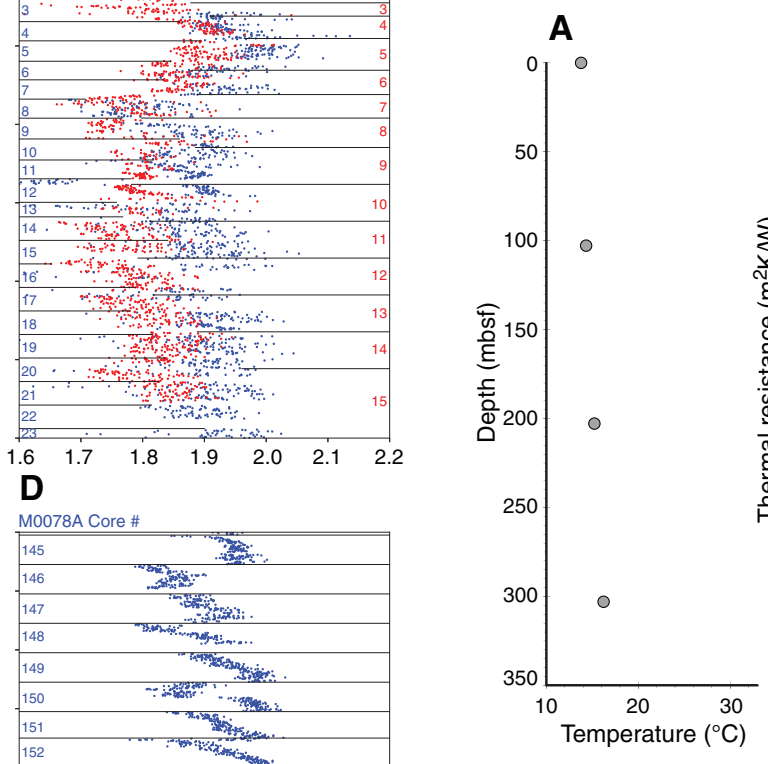

Figure F39. Temperature and thermal conductivity data, Hole M0078A. A. Seafloor and CPT temperature data. B. Thermal resistance vs. temperature derived from Bullard method. C. Thermal conductivity (corrected to in situ conditions). Note that $\mathrm{A}$ and $\mathrm{C}$ are plotted against depth (different depth intervals), and $B$ is plotted against thermal resistance.

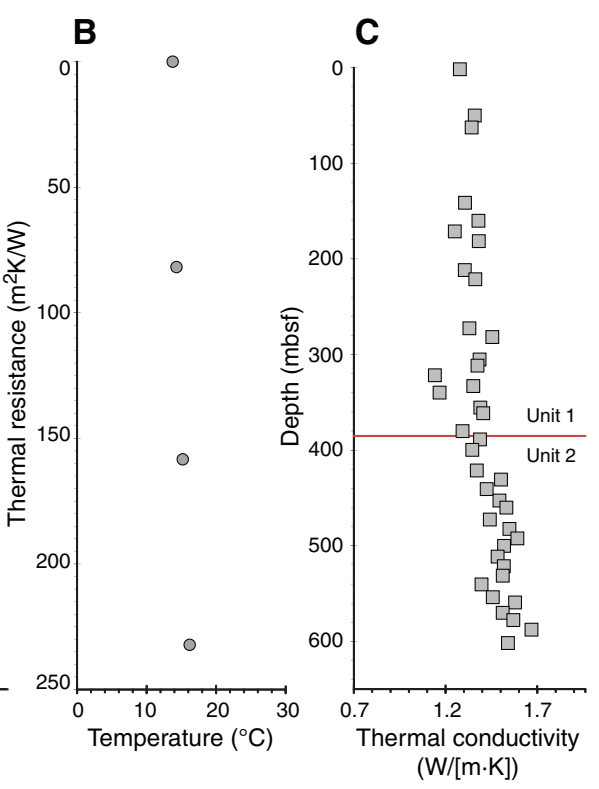

FA1 (4.1). This facies association and the associated color changes occur mainly in Unit 2. Color changes observed in FA10 and FA3 are similar to the changes observed in FA12 but are less prominent because they are thin and alternate with other facies associations, mainly in Unit 1.

Four sedimentary facies associations include $L^{*}$ values that are lower than the mean value for the hole: FA5 (greenish gray mud with dark gray to black [organic rich?] silty to sandy beds [centimeter scale]), FA2 (greenish gray mud with homogeneous centimeterthick gray mud beds), FA11 (interbedded mud/silt and centimeterthick sand beds), and FA4 (laminated greenish gray to gray mud with mud beds) (Figure F30). These facies associations are mostly confined to Unit 1.

Color reflectance values also vary between the two subunit environments (marine and isolated/semi-isolated) (Figures F29, F40). 
Figure F40. $\mathrm{L}^{*} \mathrm{a}^{*} \mathrm{~b}$ * color reflectance data box and whisker plots gathered by units, Expedition 381. Top and bottom of boxes correspond to 1 st and 3rd quartiles, solid line in middle of box shows the median, dashed line shows the mean. Ends of whiskers indicate minimum and maximum values. $\mathrm{l} / \mathrm{SI}=\mathrm{isolated} / \mathrm{semi}$ isolated.
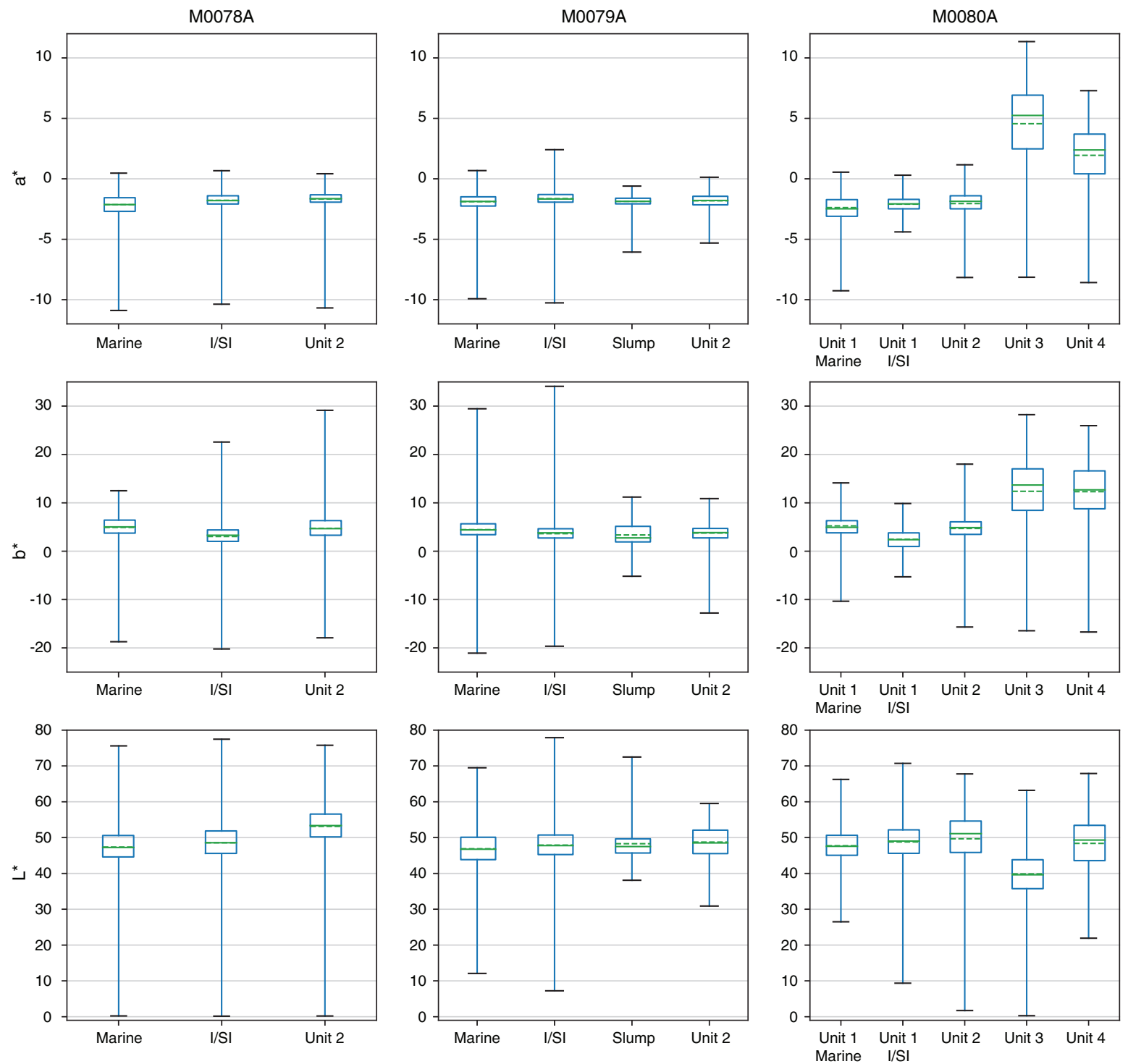

The marine subunits have lower mean $L^{*}$ and $\mathrm{a}^{*}$ values $(47$ and -2.2 , respectively) than the overall hole (50 and -1.9 , respectively) and a higher mean $b^{*}$ value (4.7) than the overall hole (3.9). These values are similar to those associated with sedimentary FA1. The isolated/semi-isolated subunits have higher mean $L^{*}$ and a* values $(51$ and -1.8 , respectively) than the overall hole (50 and -1.9 , respectively) and a lower mean $b^{*}$ value (3.7) than the overall hole (3.9). The reduced $L^{*}$ values in FA1 and marine subunits correlate with reduced magnetic susceptibility values (Figure F41; also see Magnetic susceptibility). However, no strong correlation exists between other physical properties and color reflectance. Both magnetic susceptibility and NGR values show a change in variability and values at about 330 mbsf, which is slightly shallower than the observed change in color reflectance values at about $350 \mathrm{mbsf}$ and above the Unit $1 / 2$ boundary at 385.14 mbsf. 
Figure F41. Comparison of magnetic susceptibility, $\mathrm{L}^{*}$, and $\mathrm{a}^{*}$ from 60 to $150 \mathrm{mbsf}$ interval, Hole M0078A. Left plots include environmental interpretation (lithostratigraphic units; blue $=$ marine, green $=$ isolated/semi-isolated); right plots include facies associations (white $=$ no recovery).

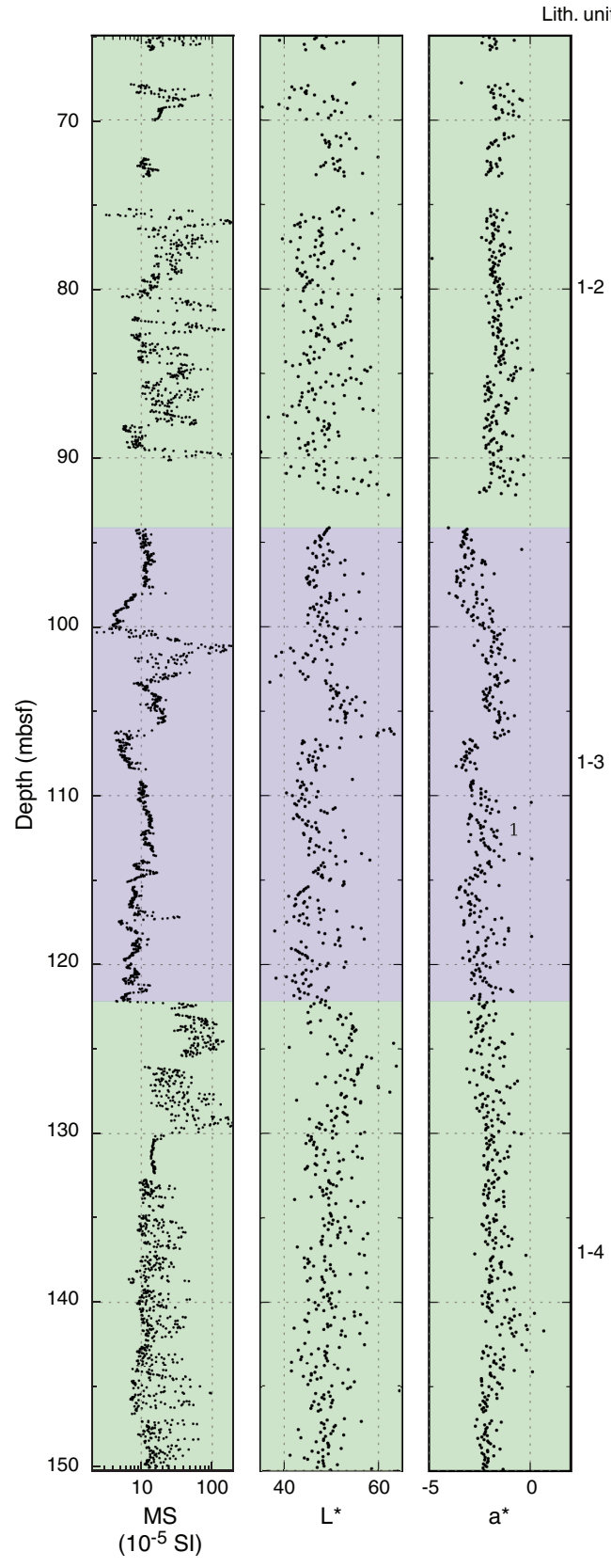

\section{Paleomagnetism}

\section{Magnetic susceptibility}

A total of 454 and 47 discrete samples were analyzed from Holes M0078A and M0078B, respectively. Frequency distribution diagrams of magnetic susceptibility $(k)$ from Hole M0078A and M0078B discrete samples, together with shipboard MSCL continuous data ( $2 \mathrm{~cm}$ interval) from whole core sections, are shown in Figure F42. Magnetic susceptibility in both Holes M0078A and M0078B shows a unimodal distribution with values that range between approximately $10 \times 10^{-6}$ and $1000 \times 10^{-6} \mathrm{SI}$. The maximum frequency of susceptibility values is between 50 and $100 \times 10^{-6} \mathrm{SI}$ (Figure F42B, F42C). A similar trend occurs in MSCL susceptibility data, where the most frequent values range between 50 and $150 \times$

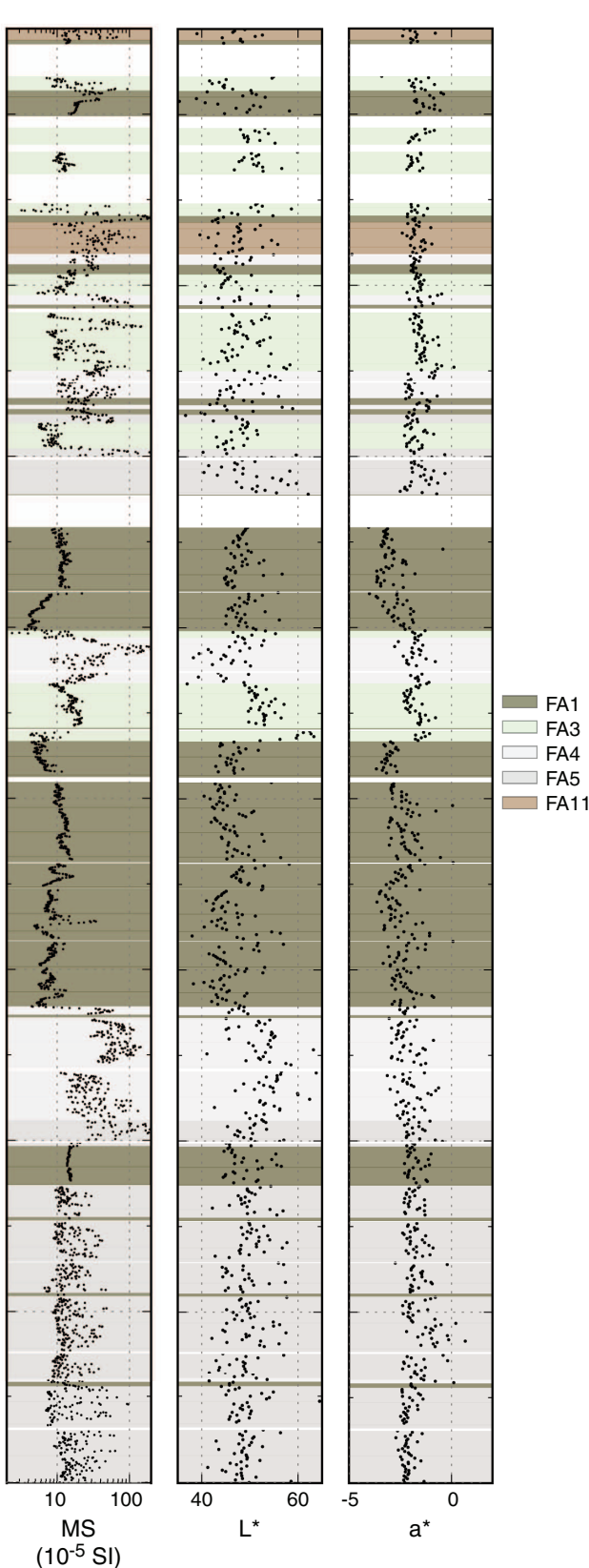

$10^{-6}$ SI (Figure F42A). Downhole distribution of magnetic susceptibility in Hole M0078A (Figure F43) shows a low variability to $\sim 300$ mbsf with values around $\sim 100 \times 10^{-6}$ SI (excluding a few samples with higher or lower susceptibility). Hole M0078B shows similar trends (Figure F44). Much higher variability occurs in Hole M0078A below $~ 300$ mbsf, where susceptibility spans two orders of magnitude from $10 \times 10^{-6}$ to $1000 \times 10^{-6} \mathrm{SI}$. This trend is much clearer when onshore discrete and shipboard continuous susceptibility data are plotted together versus depth (Figure F43E). The increased scatter in magnetic susceptibility below $\sim 300 \mathrm{mbsf}$ observed at Site M0078 may be related to changes in concentration (possibly related to compaction), nature, or grain size of the magnetic minerals or to any combination of these factors. 
Figure F42. Magnetic susceptibility frequency distribution from (A) shipboard whole core sections (MSCL) and OSP discrete samples for (B) Hole M0078A and (C) Hole M0078B.
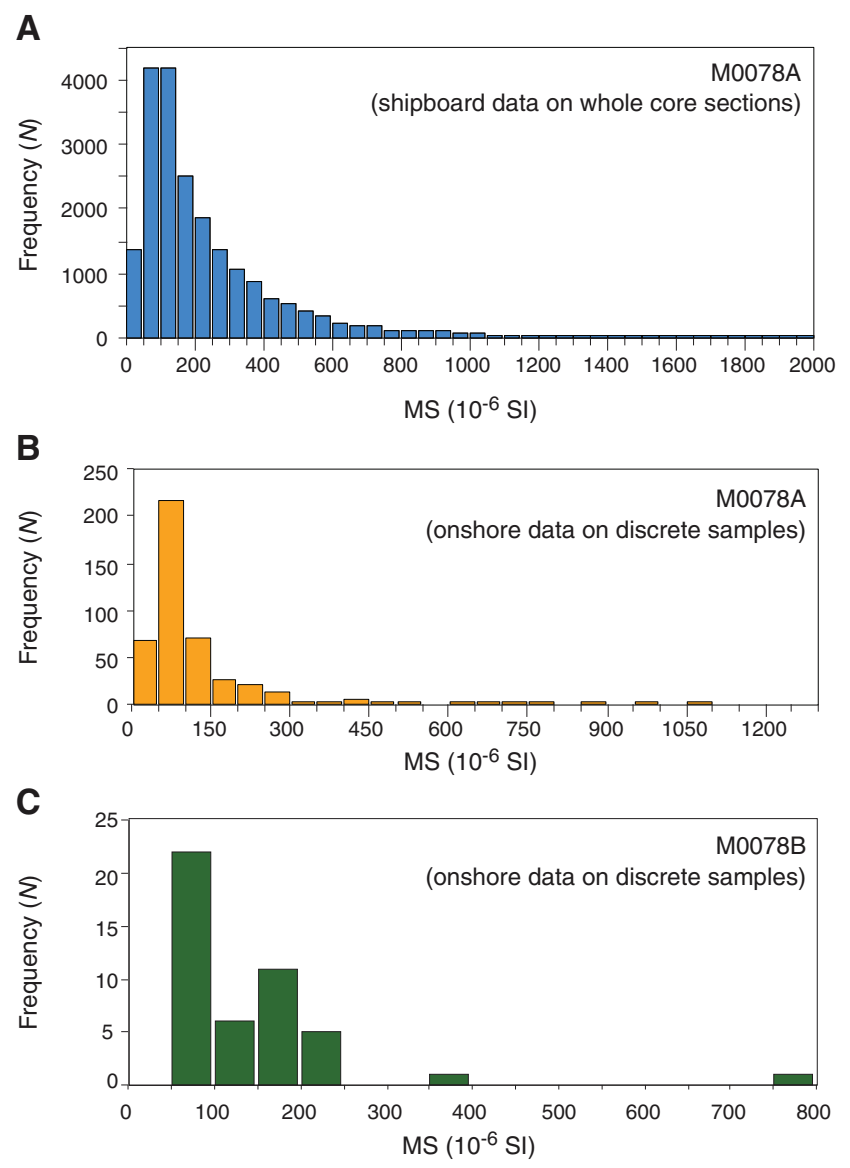

Both magnetic susceptibility and natural remanent magnetization (NRM) change in a similar fashion downhole (Figures F43, F44), suggesting a correlation between these two parameters that is clearly demonstrated by the linear trend described by the data from Site M0078 when plotted on an NRM/k diagram (Figure F45). The direct relationship between NRM and $k$ suggests that the susceptibility variation is mainly (but perhaps not exclusively) controlled by the change in concentration of a single magnetic phase in the sediment. However, the relationship between NRM and susceptibility in lithostratigraphic Unit 1 (red dots, Figure F45A) is perhaps more complex and forms both a linear trend and a small cluster localized at NRM intensity values $<10^{-3} \mathrm{~A} / \mathrm{m}$ and susceptibility values approximately between $50 \times 10^{-6}$ and $80 \times 10^{-6} \mathrm{SI}$. The samples belonging to this cluster appear to be mostly from the marine intervals/subunits of the sedimentary succession. Conversely, NRM and $k$ follow a relatively well defined linear trend in lithostratigraphic Unit 2 (interpreted to be nonmarine), which is characterized by lower NRM values compared with Unit 1 .

\section{Magnetic mineralogy}

Thermal variation of low-field magnetic susceptibility was measured for five representative samples from Hole M0078A at the University of Hawaii (USA) prior to the OSP.

Susceptibility was measured during heating-cooling cycles from room temperature to $700^{\circ} \mathrm{C}$ and back to room temperature. No argon gas was used for these experiments. A heating-cooling rate of $9^{\circ} \mathrm{C} / \mathrm{min}$ was used in all experiments. Figure $\mathbf{F} 46$ shows the results of the thermomagnetic experiments, revealing a wide range of Curie temperatures ranging between $171^{\circ}$ and $630^{\circ} \mathrm{C}$. However, most of the samples show a primary Curie temperature of $518^{\circ}-$ $577^{\circ} \mathrm{C}$, indicating the occurrence of Ti-poor titanomagnetite. Other Curie temperatures around $320^{\circ}-405^{\circ} \mathrm{C}$ may suggest the occurrence of iron sulfides (likely greigite). The variable magnetic susceptibility of greigite may be the cause of part of the observed downhole scatter in the magnetic susceptibility data.

\section{Natural remanent magnetization}

NRM direction and intensity of discrete samples were measured using the SRM 755-4000 cryogenic magnetometer (2G-Enterprises) at the University of Bremen (Germany). A total of 454 and 47 discrete cubic samples were analyzed from Holes M0078A and M0078B, respectively. All samples were stepwise demagnetized by alternating fields (AFs), and magnetization was measured after each demagnetization step. Magnetization decays steadily to nearly complete removal at the maximum AF $(100 \mathrm{mT})$ in most of the samples (Figure F47A, F47B), indicating the occurrence of low-coercivity magnetic minerals, such as magnetite or titanomagnetite. Some samples still retain $\sim 15 \%-20 \%$ of their initial magnetization after the application of the highest demagnetizing field (100 mT) (Figure F47C). In a few samples ( $<15 \%)$, remanence progressively decreased as larger demagnetizing fields were applied. Minimum values were reached at 50-60 $\mathrm{mT}$, and then values increased again at higher demagnetizing fields (Figure F47D, F47E). This behavior is typical of sediment carrying diagenetic greigite $\left(\mathrm{Fe}_{3} \mathrm{~S}_{4}\right)$.

Orthogonal demagnetization diagrams show that demagnetizing fields of 10-15 $\mathrm{mT}$ are sufficient to remove the weak viscous remanent magnetization and other secondary magnetization components. After removing these overprints, the samples displayed varied responses to the sequential demagnetization with two principal categories. Category 1 indicates the presence of NRM carried by magnetic minerals with high coercivity (median destructive field $>40 \mathrm{mT}$ ). Category 1 samples occur in the upper $400 \mathrm{~m}$ of Hole M0078A and are characterized by magnetization vectors decaying toward the origin after the $10-15 \mathrm{mT}$ AF step and more than $50 \%$ of the NRM intensity removed at $100 \mathrm{mT}$. Category 1 samples show both positive and negative inclinations (i.e., normal and reversed polarity) (Figure F47A, F47C). Category 2 samples show a relatively high susceptibility, a median destructive field of $60-70 \mathrm{mT}$, and about $20 \%$ of the initial magnetization still retained at the $100 \mathrm{mT}$ AF step. The demagnetization diagrams for Category 2 samples form lines pointing toward the origin of the axes above the 10-15 $\mathrm{mT}$ AF step, and above $40 \mathrm{mT}$ the data veer into a plane that is perpendicular to the last applied demagnetization axis (Figure F47D, F47E). This behavior is known as gyroremanent magnetization and is indicative of the occurrence of diagenetic greigite. A very small number of samples $(<2 \%)$ do not belong to these two categories because they carry more complex magnetizations (Figure F47F) whose different components could not be straightforwardly interpreted, likely because of the occurrence of a mixture of different magnetic phases.

Samples do not seem to be strongly affected by drilling-induced magnetizations commonly present in cored sediments. This component is vertical, points downward, and is typically removed at 5$10 \mathrm{mT}$. NRM directions from Holes M0078A and M0078B do not carry this vertical component. Not only are these directions not vertical (or close to vertical), they are also close to the expected magnetic field inclination at the sampling locality $\left(I=57.5^{\circ}\right)$ (Figure 
Figure F43. (A) NRM intensity, (B) magnetic susceptibility, (C) NRM on log scale, (D) magnetic susceptibility on log scale, (E) magnetic susceptibility from MSCL (gray) and onshore discrete samples (red), and (F) lithostratigraphic unit/subunit boundaries (blue = marine, white $=$ isolated/semi-isolated), Hole M0078A.
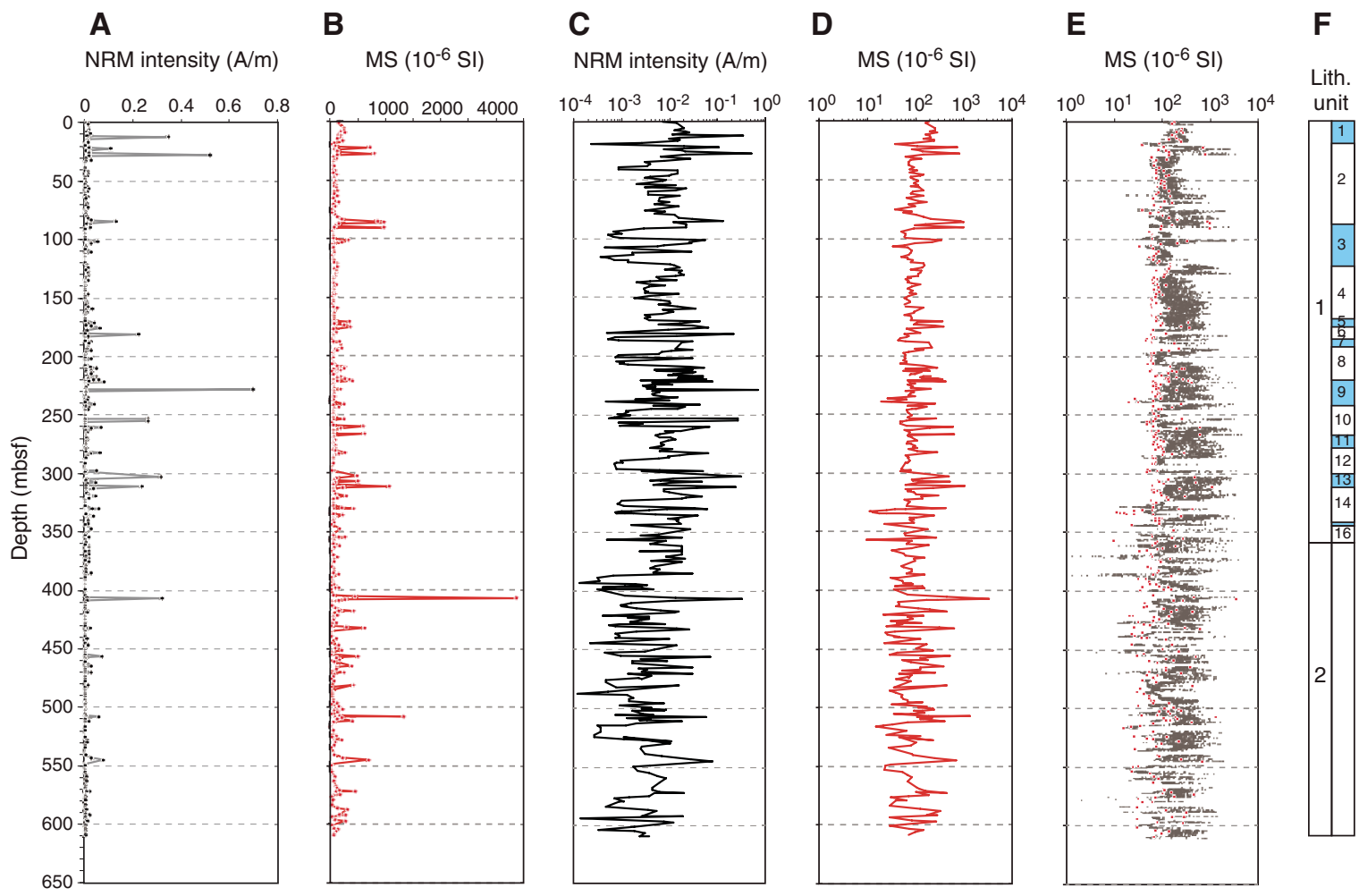

Figure F44. (A) NRM intensity, (B) magnetic susceptibility, (C) NRM on log scale, (D) magnetic susceptibility on log scale, (E) magnetic susceptibility from MSCL (gray) and onshore discrete samples (red), and (F) lithostratigraphic unit/subunit boundaries (blue = marine, white = isolated/semi-isolated), Hole M0078B.

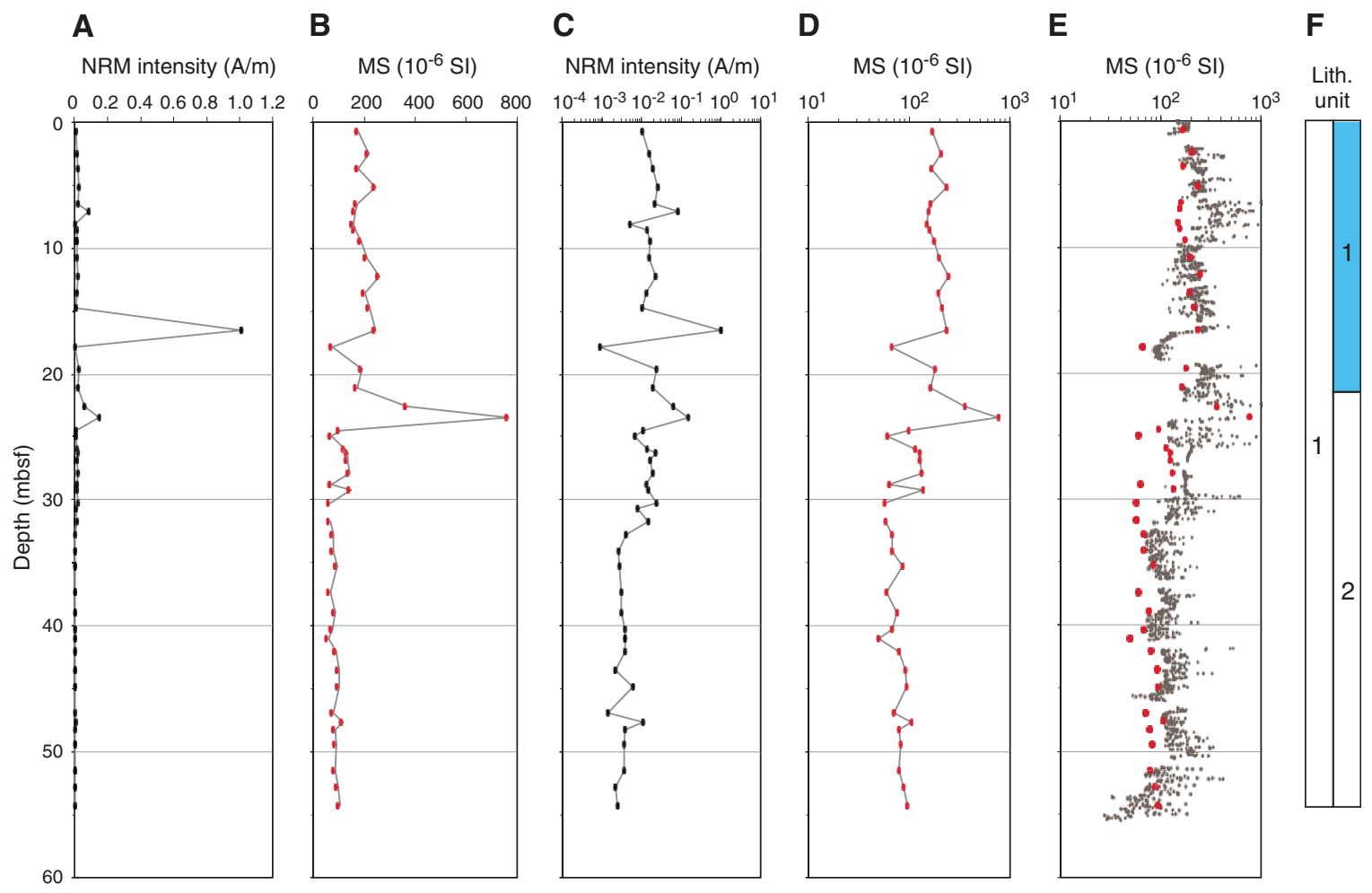


Figure F45. NRM intensity vs. magnetic susceptibility, (A) Hole M0078A and (B) Hole M0078B.
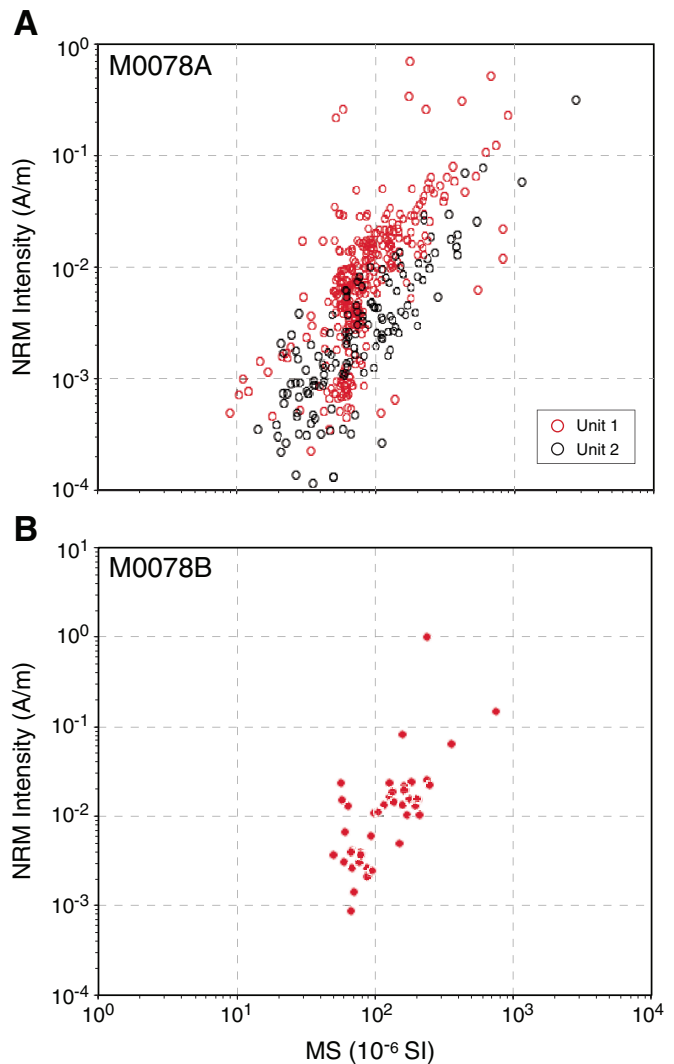

F48). After demagnetization at $40 \mathrm{mT}$, secondary magnetization components were removed in all the analyzed samples. For this reason, the remanence direction (declination and inclination) after demagnetization at $40 \mathrm{mT}$ can be considered parallel to the characteristic remanent magnetization (ChRM) component in each sample.

The remanence inclination after demagnetization at $40 \mathrm{mT}$ is consistent with the expected inclination in both Holes M0078A and M0078B (Figure F49). These data suggest that the ancient geomagnetic field has reliably been recorded by these sediments.

\section{Magnetostratigraphy}

Inclination values of the remanence after demagnetization at 40 $\mathrm{mT}$ (used here as representative of the ChRM components) show a downhole change from positive (normal polarity) to negative (reversed polarity) consistent with the expected magnetic field inclination values at the sampling latitude. Some of these inclination variations may represent geomagnetic field excursions rather than true reversals. One of the main objectives for the OSP paleomagnetic work was to produce magnetostratigraphic logs of the sedimentary sequences from Sites M0078, M0079, and M0080. The excellent magnetic stability of all the specimens will allow a potentially reliable magnetostratigraphic reconstruction. Figure F49 shows the inclination data for Holes M0078A and M0078B together with a preliminary magnetostratigraphy and its interpretative correlation with the geomagnetic instability timescale (GITS) of Singer (2014) (dashed lines with question marks). The produced magnetostratigraphy shows a predominantly normal polarity in the upper $385.11 \mathrm{~m}$ (Sample 381-M0078A-125R-2, 12-14 cm). Just below this
Figure F46. Low-field susceptibility vs. temperature $(k-T)$ experiment results for five samples obtained before the onshore phase, Hole M0078A. Red = heating path, blue $=$ cooling path .
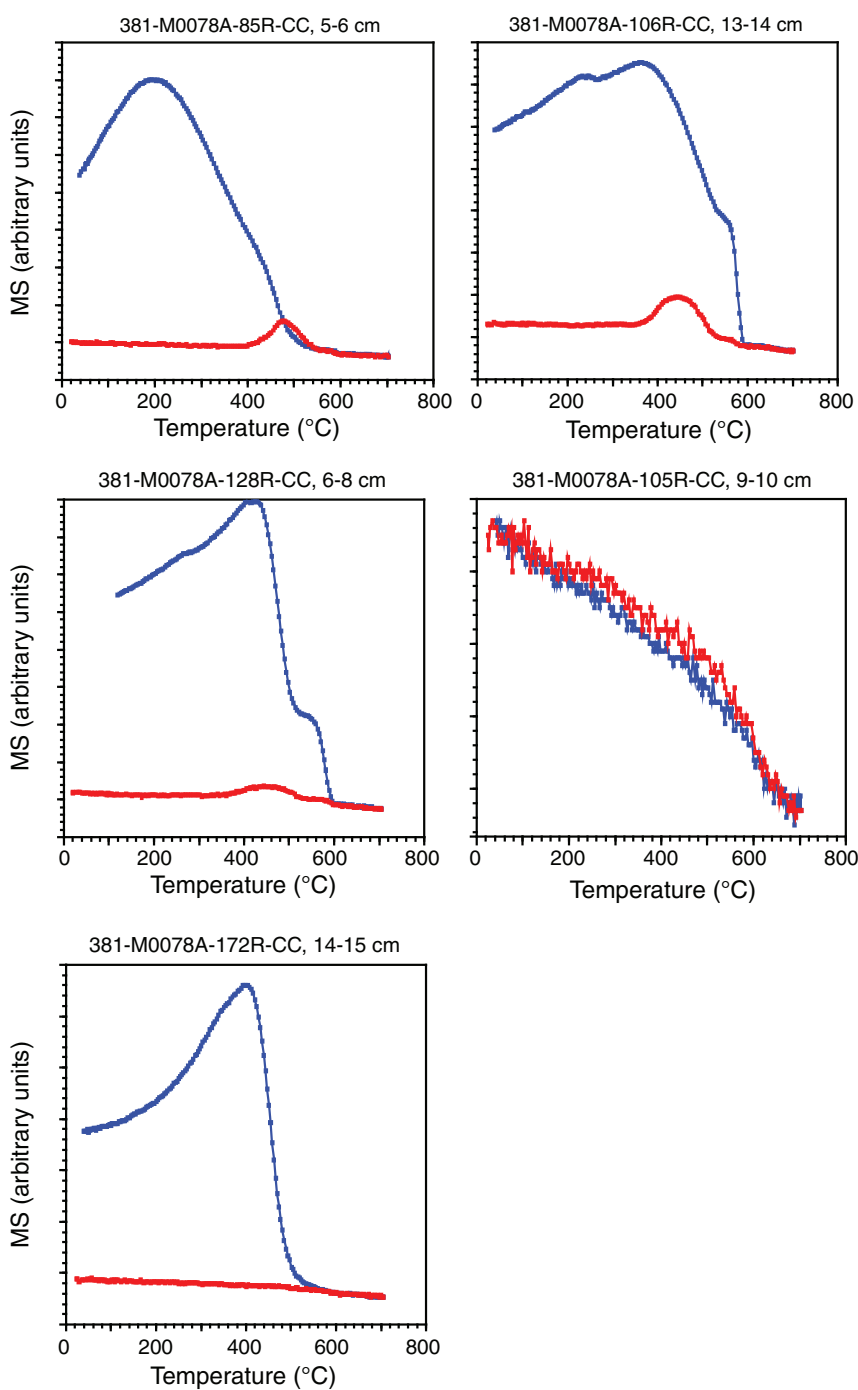

sample at 385.14 mbsf, a major change in lithologic and chemical features marks the transition to Unit 2 (see Lithostratigraphy). In this uppermost interval characterized by a normal polarity, six Hole M0078A samples and one Hole M0078B sample have a reversed polarity consistent with the expected geomagnetic field inclination (i.e., $-57.5^{\circ}$ ). These anomalous inclinations are marked with white lines in the magnetostratigraphic columns in Figure F49C. These samples may have recorded some of the geomagnetic field excursions that occurred during the Brunhes Chron (e.g., Singer, 2014). Additional rock magnetic experiments and biostratigraphic constraints will, however, be necessary to establish whether and which one of these inclination changes are actual magnetic field excursions.

From the "shipboard" work, two biomarkers were defined with moderate confidence in Unit 1 that could be used to tighten the proposed magnetostratigraphic correlations with the GITS. The LDO of E. huxleyi (FAD at $0.29 \mathrm{Ma}$ ) was observed at $121.82 \mathrm{mbsf}$, and the LAD of P. lacunosa (0.43 Ma) was observed at $298.6 \mathrm{mbsf}$ (see Micropaleontology) (Figure F49). It is important to note that $P$. lacunosa was only observed in a single sample, and because of the 
Figure F47. (Top) Orthogonal projections (Zijderveld diagrams; solid symbols = projection onto horizontal plane, open symbols = projection onto vertical plane) and (Bottom) relative decay paths of remanence during demagnetizations for six representative samples, Hole M0078A. Red = data used to compute the characteristic component (blue line).

\section{A}

381-M0078A-126R-1, 11-13 cm
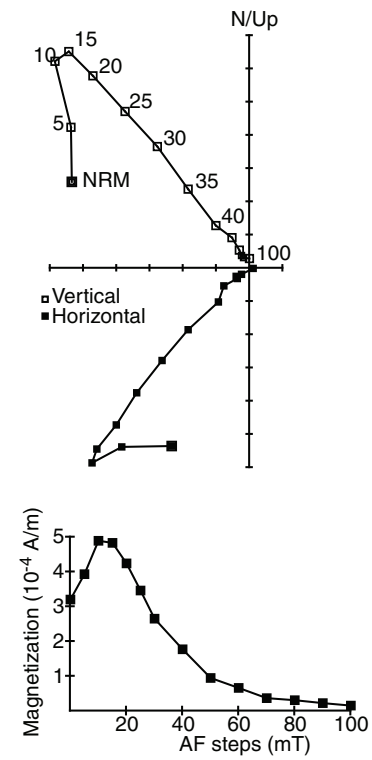

D

381-M0078A-107R-2, 15-17 cm
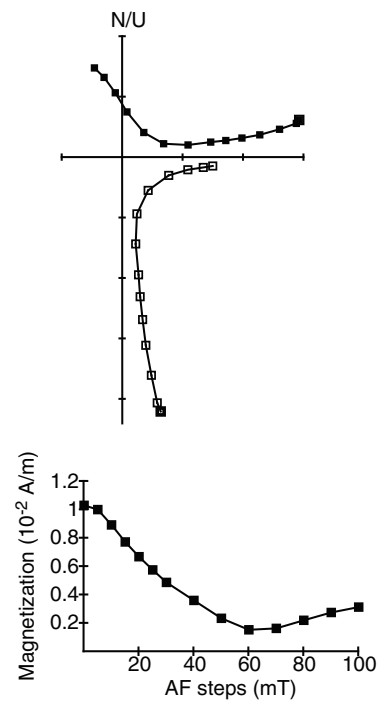

B

381-M0078A-108R-1, 36-38 cm
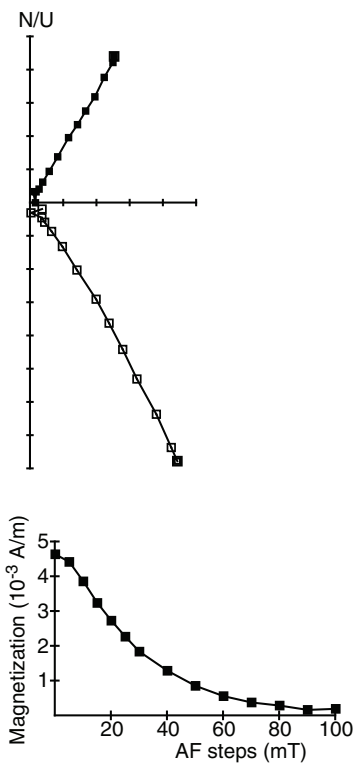

E

381-M0078A-111R-2, 5-7 cm
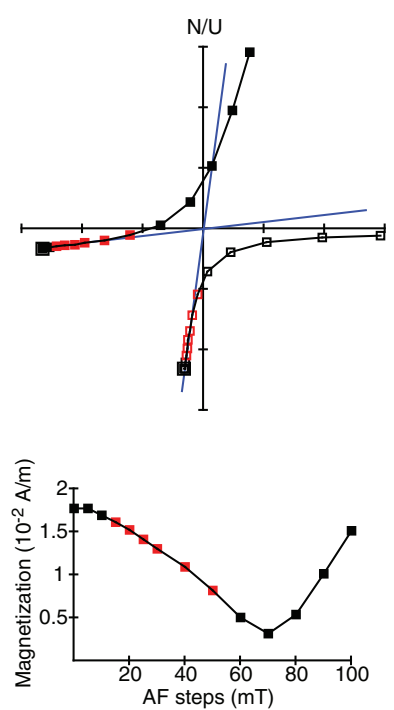

C

$381-\mathrm{M} 0078 \mathrm{~A}-12 \mathrm{H}-1,35-37 \mathrm{~cm}$
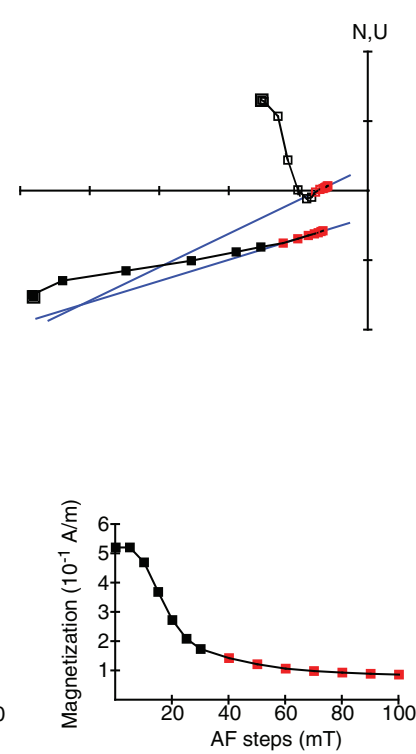

$\mathbf{F}$

381-M0078A-26H-2, 25-27 cm
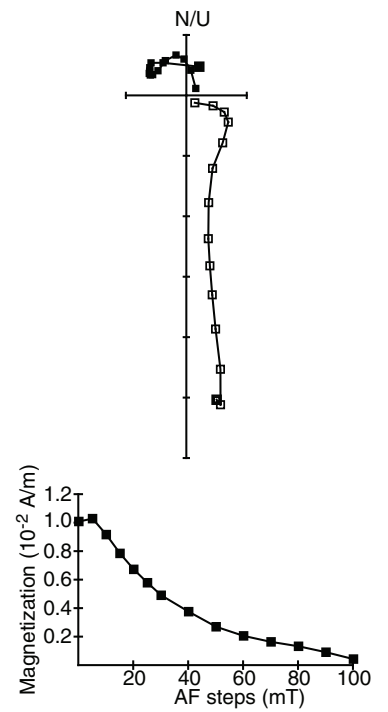

punctuated nature of marine environments in the Corinth basin, the precision of both biohorizons is inherently low. These two biomarkers would suggest that the sediment shallower than 121.82 mbsf and deeper than 298.6 mbsf cannot be older than 0.29 Ma or younger than $0.43 \mathrm{Ma}$, respectively. These biomarkers would therefore imply that the potential excursion observed at $12.28 \mathrm{mbsf}$ in Hole M0078A and 7.02 mbsf in Hole M0078B (Figure F49C), if indicative of true excursions, may only be correlated with one of the excursions younger than Pringle Falls (211 ka; Singer, 2014). Similarly, the potential excursion observed at 307.06 mbsf in Hole M0078A may only be correlated with one of the excursions older than West Eifel 5 (528 ka; Singer, 2014). However, given the lack of firm biostratigraphic constraints from Holes M0078A and M0078B, any correlation between the potential excursions observed in Holes M0078A and M0078B and those from the GITS currently remains highly speculative.

Sample 381-M0078A-125R-2, 100-102 cm (385.99 mbsf), at the top of Unit 2 yields a negative inclination (reversed polarity) and marks the boundary with a longer reversed polarity interval below. This major polarity transition might represent the Brunhes/Matuyama boundary (0.773 Ma; Singer, 2014). The interpretation of this polarity transition as the Brunhes/Matuyama boundary remains speculative. Below 385.99 mbsf, a number of samples with normal polarity occur too, including a relatively long normal polarity interval at $519.32-574.72 \mathrm{mbsf}$. The lack of biostratigraphic constraints from Unit 2, however, prevents us from drawing definitive 
Figure F48. Lower hemisphere equal-area stereographic projections of NRM directions from Hole M0078A and M0078B samples. Red dashed circle $=$ geocentric axial dipole expected inclination (i.e., $57.5^{\circ}$ ) for the site latitude. Solid dots $=$ directions with a positive (normal polarity) inclination, open dots $=$ directions with a negative (reversed polarity) inclination.
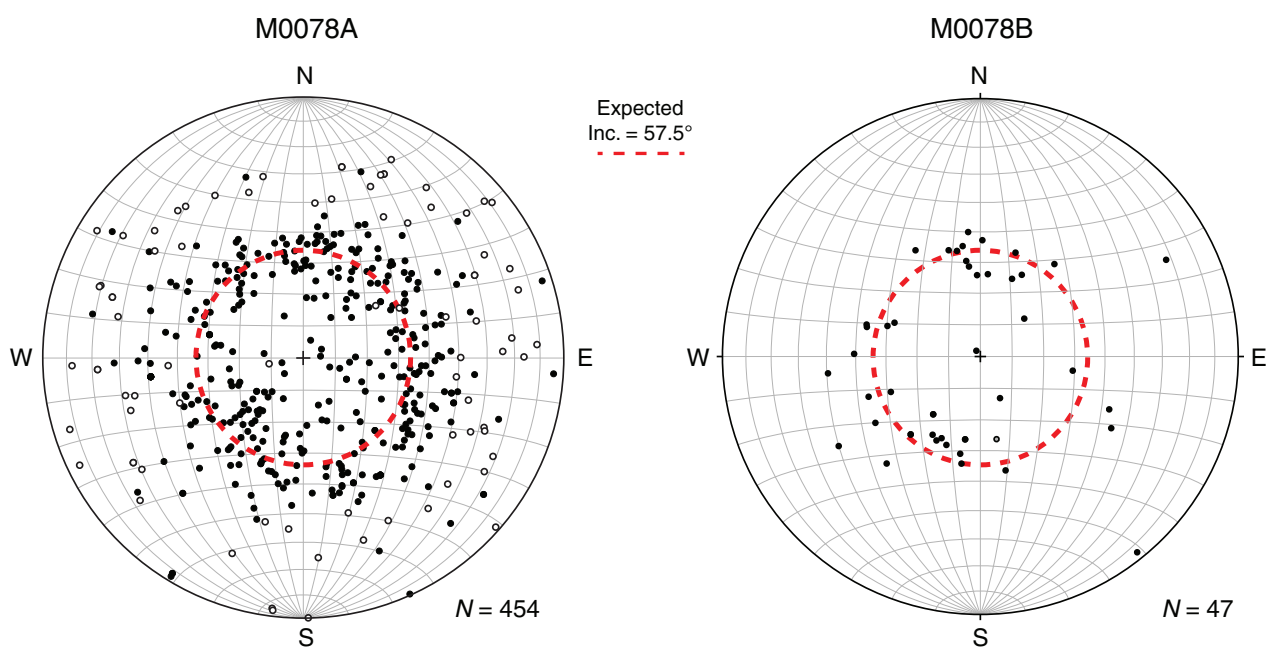

Figure F49. Inclination of remanence after demagnetization at $40 \mathrm{mT}$ with unit/subunit boundaries, (A) Hole M0078A and (B) Hole M0078B. Red dotted lines = expected inclination at the site latitude (i.e., $57.5^{\circ}$ ). Subunits: blue $=$ marine, white $=$ isolated/semi-isolated. C. Magnetostratigraphic logs based on inclination data in $\mathrm{A}$ and $\mathrm{B}$ showing intervals characterized by normal (black) and reversed (white) polarity. Loosely constrained $E$. huxleyi first appearance and $P$. lacunosa last occurrence from calcareous nannofossil analyses (see Micropaleontology). Dashed lines with question marks indicate correlation between site magnetostratigraphy (polarity reversals) and GITS, and they are speculative at this time. $M / B=$ Matuyama/Brunhes.

A

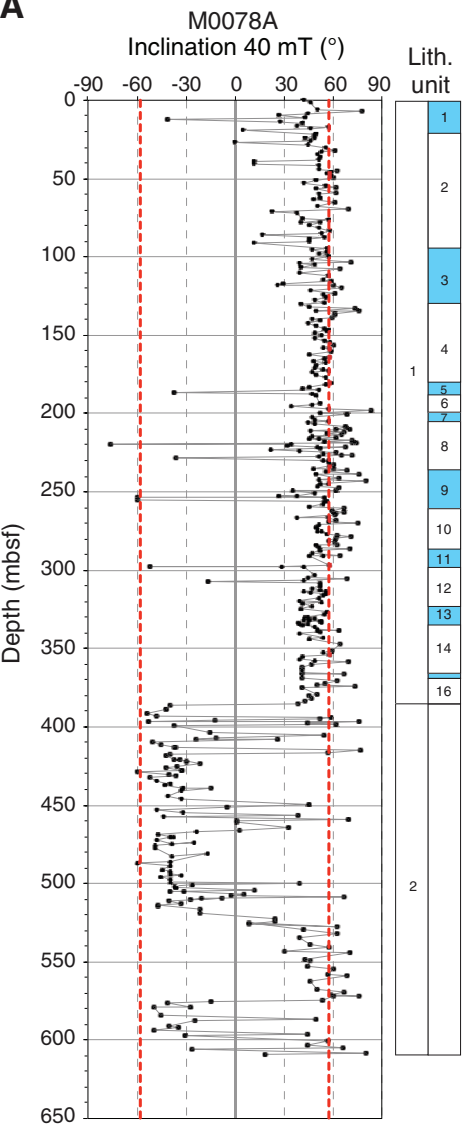

B

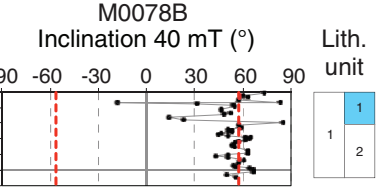

C

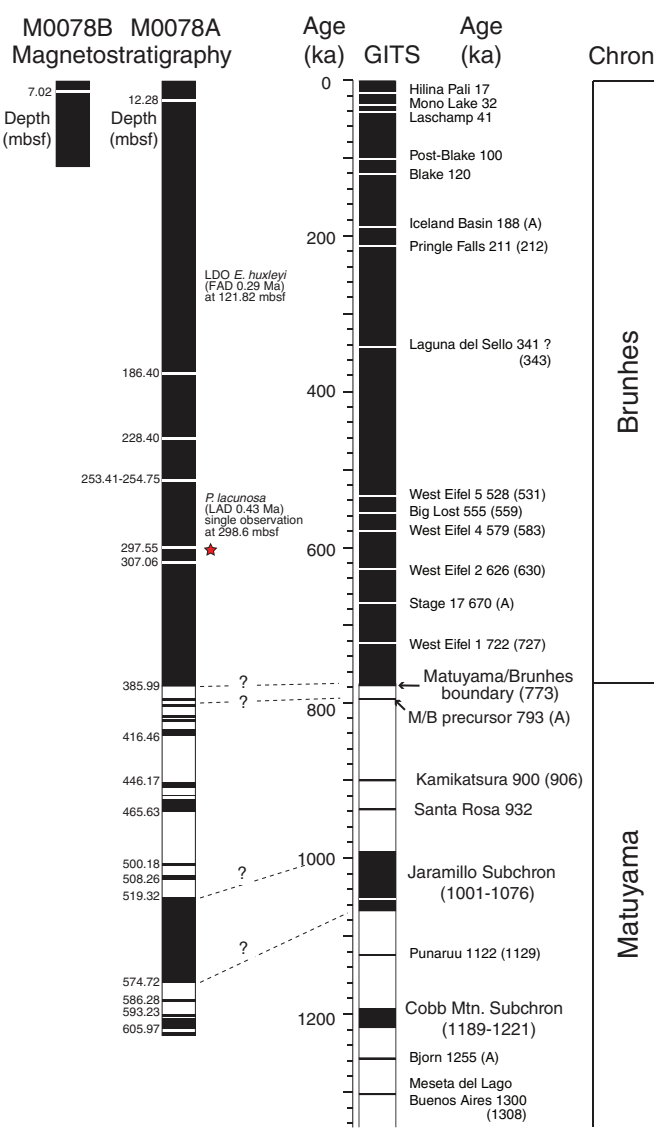


conclusions on the real nature and age of the major polarity change at 385.99 mbsf or any of the deeper reversals observed. Between 519.32 and $574.72 \mathrm{mbsf}$, a relatively long interval characterized by a normal polarity occurs that might represent the Jaramillo Subchron (1.00-1.08 Ma).

\section{Core-log-seismic integration}

In the absence of new velocity information at Site M0078 from downhole logging or core measurements, MSCL density and a linear velocity function based on seismic data were used to generate synthetic seismograms. Unfortunately, neither MSCL nor discrete $V_{\mathrm{P}}$ measurements produced reliable velocity data for Site M0078 (Figure F50), and downhole logging was not successful at this site. Therefore, the linear velocity model developed prior to the expedition (see Figure F18 in the Expedition 381 methods chapter [McNeill et al., 2019b]) and a slightly modified version from offshore core-seismic integration were used as a starting point for onshore synthetic seismograms. MSCL density values from Holes M0078A and M0078B were combined and thoroughly quality checked and filtered using the approach described in Core-log-seismic integration in the Expedition 381 methods chapter (McNeill et al., 2019b). The resulting density log was depth shifted to sea level (Figure F51; Table T18).

Despite a lack of new downhole velocity information, the synthetic seismograms can be reliably tied to the seismic data with limited adjustments to the initial velocity profile (Figure F51). The main high-reflectivity horizons in seismic Unit 2 (lithostratigraphic Unit 1) match with the seismic data remarkably well. The lower reflectivity sequences in seismic Unit 1 (lithostratigraphic Unit 2) proved to be more challenging to match because of the lack of impedance contrasts in the core and seismic records. However, at least two low-reflectivity horizons in seismic Unit 1 can be potentially traced in the synthetic seismogram and tied to seismic data.

The output velocity profile from the synthetics generation ( $\mathrm{Ta}-$ ble T19) suggests that $V_{\mathrm{P}}$ often deviates from the linear velocity model but does not exhibit consistent variations with respect to the lithostratigraphic subunits (Figure F52). The resulting time-depth conversion function is shown in Figure F53, and the time-depth relationship (TDR) for the high-reflectivity seismic horizons is listed in Table T20 (full TDR is in M0078_TDR.xlsx in CLSI in Supplementary material).

One of the largest uncertainties in positioning seismic horizons in depth and correlating them with the core record proved to be the finite resolution of the seismic data. The interpretation by Nixon et al. (2016) placed seismic unit and sequence boundaries at the peak amplitude of a seismic reflection, whereas our analysis of synthetic seismograms indicates that the first break of a reflection provides a better estimate of the depth to the corresponding impedance contrast. Converted to depth, the time difference between picking "zero crossing" (wherever possible to identify) and the peak of a wavelet can reach 10-15 m, introducing significant uncertainty for coreseismic integration (Figure F53; Table T20). An estimated calculation of the vertical resolution for these seismic data agrees with this estimation. For example, the peak frequency of the source wavelet extracted from the data around the site is $30-40 \mathrm{~Hz}$ (see Figure F17 in the Expedition 381 methods chapter [McNeill et al., 2019b]). Assuming a vertical resolution of roughly a quarter of the wavelength (e.g., Widess, 1973) and an average velocity of $2000 \mathrm{~m} / \mathrm{s}$, this translates to a vertical resolution of $12-17 \mathrm{~m}$.
Figure F50. Shore-based discrete sample $V_{\mathrm{p}}$ measurements compared with initial pre-expedition linear velocity model (see Core-log-seismic integration in the Expedition 381 methods chapter [McNeill et al., 2019b] for details) and interval $V_{p}$ from offshore core-log-seismic integration (CLSI), Site M0078. Discrete $V_{P}$ measurements significantly underestimate $P$-wave velocity (except for a small subset of measurements above $\sim 150 \mathrm{mbsf}$ ) and cannot be used for building synthetic seismograms.

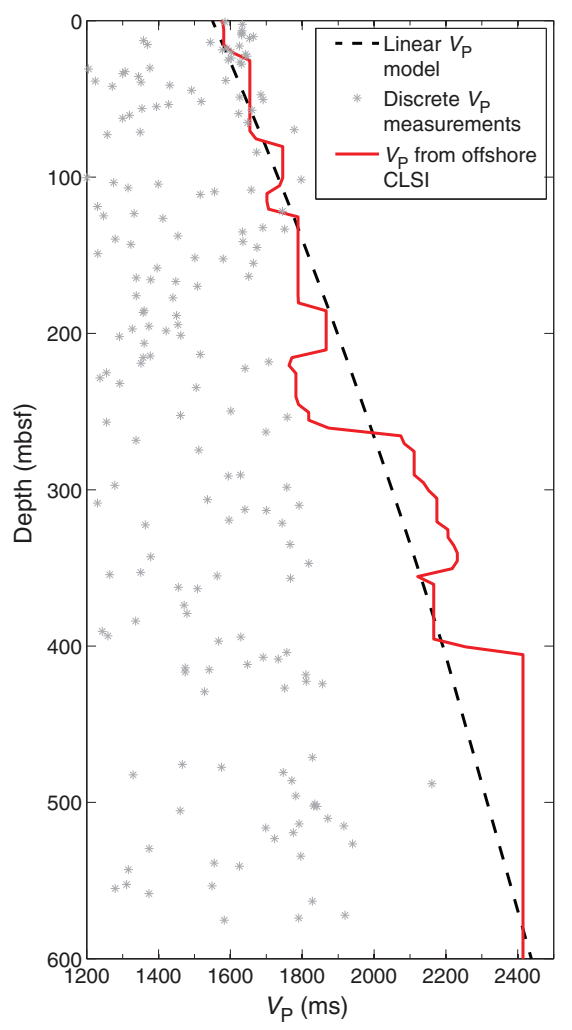

The TDR established with synthetic seismograms at Site M0078 allows for direct comparison of major lithologic boundaries identified in the cores with the seismic data. Figure F54 shows a section of the seismic profile crossing Site M0078, the synthetic traces, and the unit and subunit boundaries identified from a combination of lithologic and paleontological observations. High-reflectivity horizons in the seismic profile clearly correspond to marine subunits in the core, confirming the interpretation of Nixon at el. (2016) and others before. For example, seismic Horizon $\mathrm{H} 2$ top and bottom clearly correspond to the lithostratigraphic Subunit 1-3 (marine) boundaries, and seismic Horizon H3 top and bottom correspond to thin marine intervals in Subunits 1-5 and 1-7, respectively. However, the subunit boundaries predominantly map onto the first break of a given seismic reflection, not the peak (Figure F53).

Below 250 mbsf, correlating seismic reflectors with subunit boundaries in Hole M0078A becomes more challenging because subunits are thinner and may be incomplete at the base of Unit 1 at this site. In this depth range, some of the seismic phases that correspond to the boundaries between the marine and isolated/semi-isolated subunits are different from the interpreted horizons (Figures F53, F54). For example, the Horizon H5 top corresponds to the top of isolated/semi-isolated lithostratigraphic Subunit 1-12, not a marine interval.

The depth of the unit boundary/unconformity (U) in the seismic data directly matches the lithostratigraphic Unit $1 / 2$ boundary. 
Figure F51. Final synthetic seismogram as seen in Petrel synthetic generation window showing true vertical depth (TVD) below sea level, TWT, input density and velocity curves, computed reflection coefficient series, ten traces of R/V Maurice Ewing Line 42 north-south profile crossing Site M0078 (Figure F2), synthetic seismogram, ten more traces of the same seismic line, and final velocity profile resulting from tying the synthetic to the seismic data. mbsl = meters below sea level.

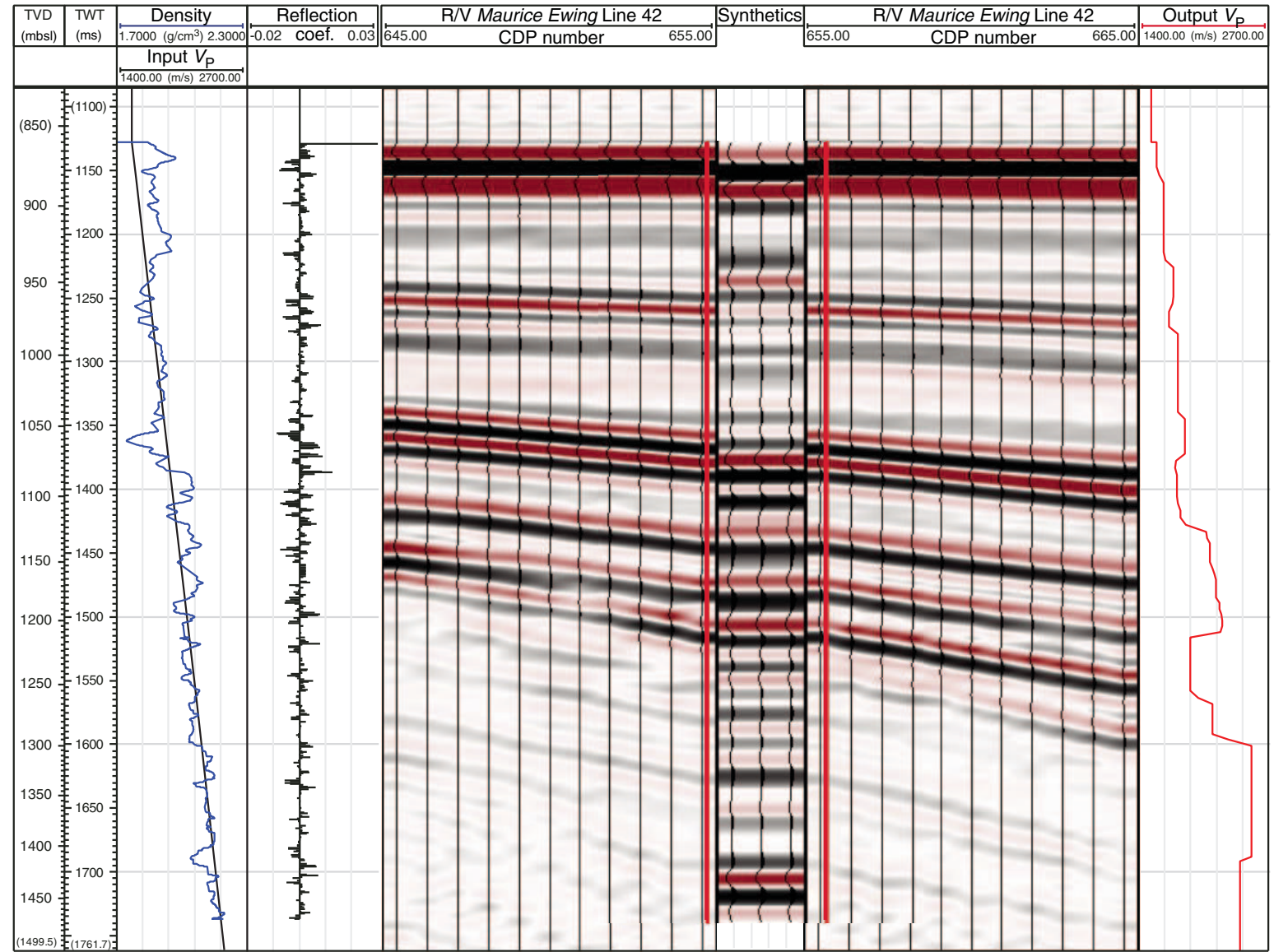

Therefore, we interpreted seismic Unconformity $U$ to represent the lithostratigraphic unit boundary identified in the core. Below the Unit $1 / 2$ boundary, no bright reflectors were observed in the seismic record, consistent with the lack of lithostratigraphic boundaries in the core. However, two low-amplitude reflectors clearly correspond to changes in density and magnetic susceptibility at 480 and $\sim 545$ mbsf. These boundaries may potentially correspond to paleoenvironmental changes, as suggested by preliminary "shipboard" micropaleontology, but the nature of these transitions and their ex-
Table T18. Density profile used for synthetics generation at Site M0078 derived from filtered MSCL data, combined for Holes M0078A and M0078B. Download table in CSV format.

Table T19. Output velocity profile from synthetics generation, Site M0078. Download table in CSV format.

pression in the sedimentary record and/or physical properties are not yet well characterized. 
Figure F52. Final onshore CLSI $V_{\mathrm{p}}$ profile compared with initial pre-expedition linear velocity model and offshore CLSI results, Site M0078. Core-based onshore lithostratigraphic unit and subunits are also shown. Unit 1 subunits: blue $=$ marine, green $=$ isolated $/$ semi-isolated. Blue line $=$ Unit $1 / 2$ boundary . Yellow = Unit 2.

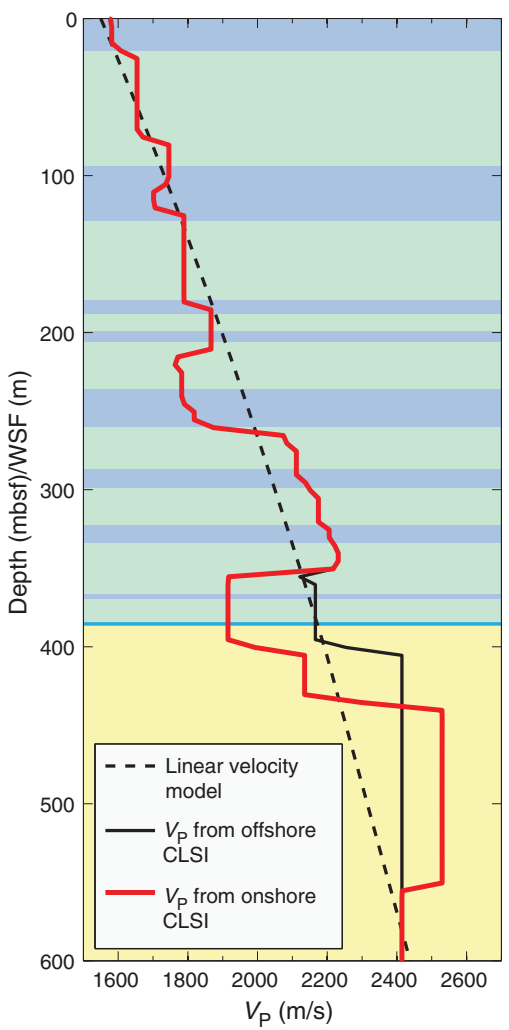

Figure F53. Time-depth conversion function generated by onshore CLSI and the range of depths and time picks for the main seismic horizons $(\mathrm{H} 1-\mathrm{H} 6)$, Site M0078. $t=$ top, $b=$ bottom, $U=$ seismic unit boundary (which corresponds to lithostratigraphic Unit $1 / 2$ boundary). Maximum values correspond to the peak of a seismic reflector and minimum values correspond to the first break of the same reflector (wherever it was possible to identify one in the seismograms). Core-based lithostratigraphic unit and subunits are also shown. Unit 1 subunits: blue $=$ marine, green $=$ isolated $/$ semi-isolated. Blue line $=$ Unit $1 / 2$ boundary. Yellow $=$ Unit 2 . The illustrated potential difference in depth of seismic boundaries is dependent on the method of picking the seismic reflector. Nevertheless, correspondence between subunit boundaries and seismic horizons is good.

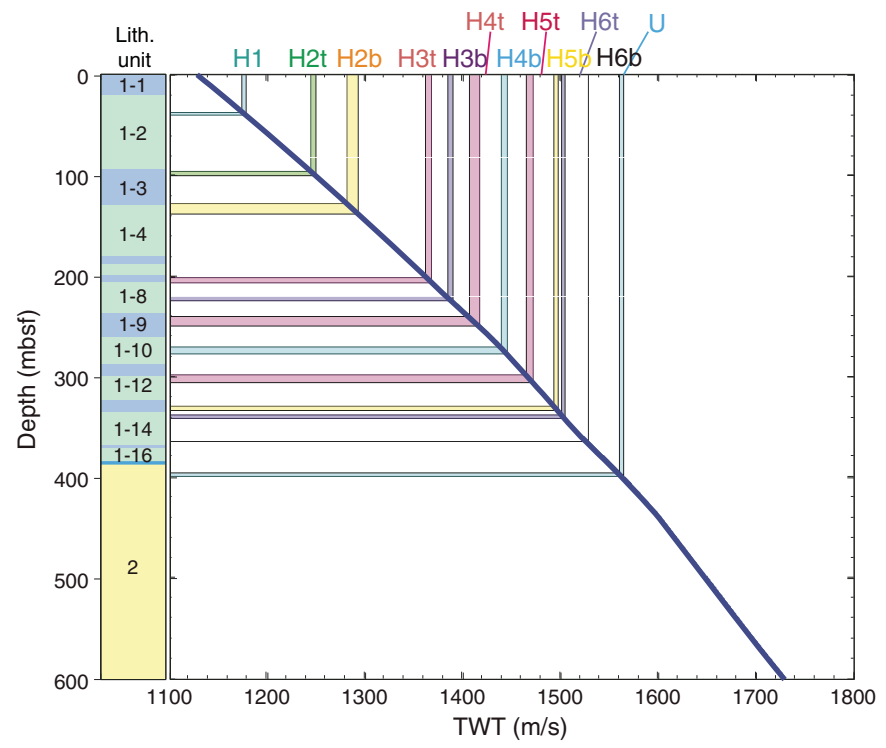

Table T20. Primary seismic horizons for Maurice Ewing Line 42, Site M0078. Two options for choosing a horizon position are the peak of seismic reflection amplitude and the preceding zero or first break two-way traveltime (TWT). $\mathrm{U}=$ seismic unit boundary/unconformity. Download table in CSV format.

\begin{tabular}{|c|c|c|c|c|c|c|c|c|c|}
\hline $\begin{array}{l}\text { Seismic } \\
\text { horizon }\end{array}$ & $\begin{array}{l}\text { TWT peak } \\
\text { (ms) }\end{array}$ & $\begin{array}{c}\text { TWT first } \\
\text { break (ms) }\end{array}$ & $\begin{array}{l}\text { Depth } \\
\text { peak } \\
\text { (mbsl) }\end{array}$ & $\begin{array}{l}\text { Depth } \\
\text { first break } \\
\text { (mbsl) }\end{array}$ & $\begin{array}{l}\text { Depth } \\
\text { peak } \\
\text { (mbsf) }\end{array}$ & $\begin{array}{l}\text { Depth first } \\
\text { break } \\
\text { (mbsf) }\end{array}$ & $\begin{array}{l}\text { Interval velocity } \\
\text { at peak } \\
(\mathrm{m} / \mathrm{s})\end{array}$ & $\begin{array}{l}\text { Interval velocity } \\
\text { at first break } \\
(\mathrm{m} / \mathrm{s})\end{array}$ & $\begin{array}{l}\text { Apparent dip } \\
\text { in north-south } \\
\text { direction }\left(^{\circ}\right)\end{array}$ \\
\hline Seabed (time) & 1148 & 1141 & & & & & 1550.0 & 1550.0 & 0 \\
\hline $\mathrm{H} 1$ (time) & 1178.4 & 1174.47 & 900.5 & 897.2 & 41.0 & 37.7 & 1654.0 & 1654.3 & 0 \\
\hline $\mathrm{H} 2$ top (time) & 1249.6 & 1244.6 & 960.5 & 956.1 & 101.0 & 96.6 & 1745.7 & 1745.5 & 2 \\
\hline H2 bottom (time) & 1293 & 1281.5 & 998.3 & 988.0 & 138.8 & 128.5 & 1788.8 & 1794.9 & 2 \\
\hline H3 top (time) & 1367.8 & 1361.8 & 1066.1 & 1060.5 & 206.6 & 201.0 & 1870.6 & 1866.0 & 4 \\
\hline H3 bottom (time) & 1389.7 & 1384.9 & 1085.9 & 1081.7 & 226.4 & 222.2 & 1783.4 & 1771.2 & 5 \\
\hline H4 top (time) & 1417.1 & 1406.6 & 1110.3 & 1101.0 & 250.8 & 241.5 & 1819.1 & 1782.3 & 5 \\
\hline H4 bottom (time) & 1445.4 & 1438.7 & 1137.9 & 1130.9 & 278.4 & 271.4 & 2114.5 & 2085.3 & 7 \\
\hline H5 top (time) & 1471.57 & 1464.55 & 1165.7 & 1158.1 & 306.2 & 298.6 & 2176.3 & 2146.4 & 8 \\
\hline H5 bottom (time) & 1496.8 & 1492.7 & 1193.2 & 1188.7 & 333.7 & 329.2 & 2214.2 & 2206.3 & \\
\hline H6 top (time) & 1504 & 1500.57 & 1201.2 & 1197.4 & 341.7 & 337.9 & 2229.0 & 2229.9 & 10 \\
\hline H6 bottom (time) & 1527.8 & & 1225.9 & & 366.4 & & 1913.1 & & \\
\hline U (time) & 1563.6 & 1559.85 & 1260.2 & 1256.6 & 400.7 & 397.1 & 1999.9 & 1927.9 & 13 \\
\hline Basement (time) & 1874.4 & & 1635.5 & & 776.0 & & 2414.7 & & \\
\hline
\end{tabular}


Figure F54. MSCL data (density, magnetic susceptibility, and NGR) converted to time (TWT) alongside lithostratigraphic units and subunits and synthetic and seismic data (Maurice Ewing Line 42, CDP 655-665), Site M0078. Black dots = MSCL data, red lines = smoothed MSCL data (running average). Unit 1 subunits: blue $=$ marine, green $=$ isolated $/$ semi-isolated. Horizontal blue line $=$ Unit $1 / 2$ boundary. Yellow $=$ Unit 2. Seismic: solid color lines $=$ seismic interpretation by Nixon et al. (2016), vertical red line = position of Hole M0078A.

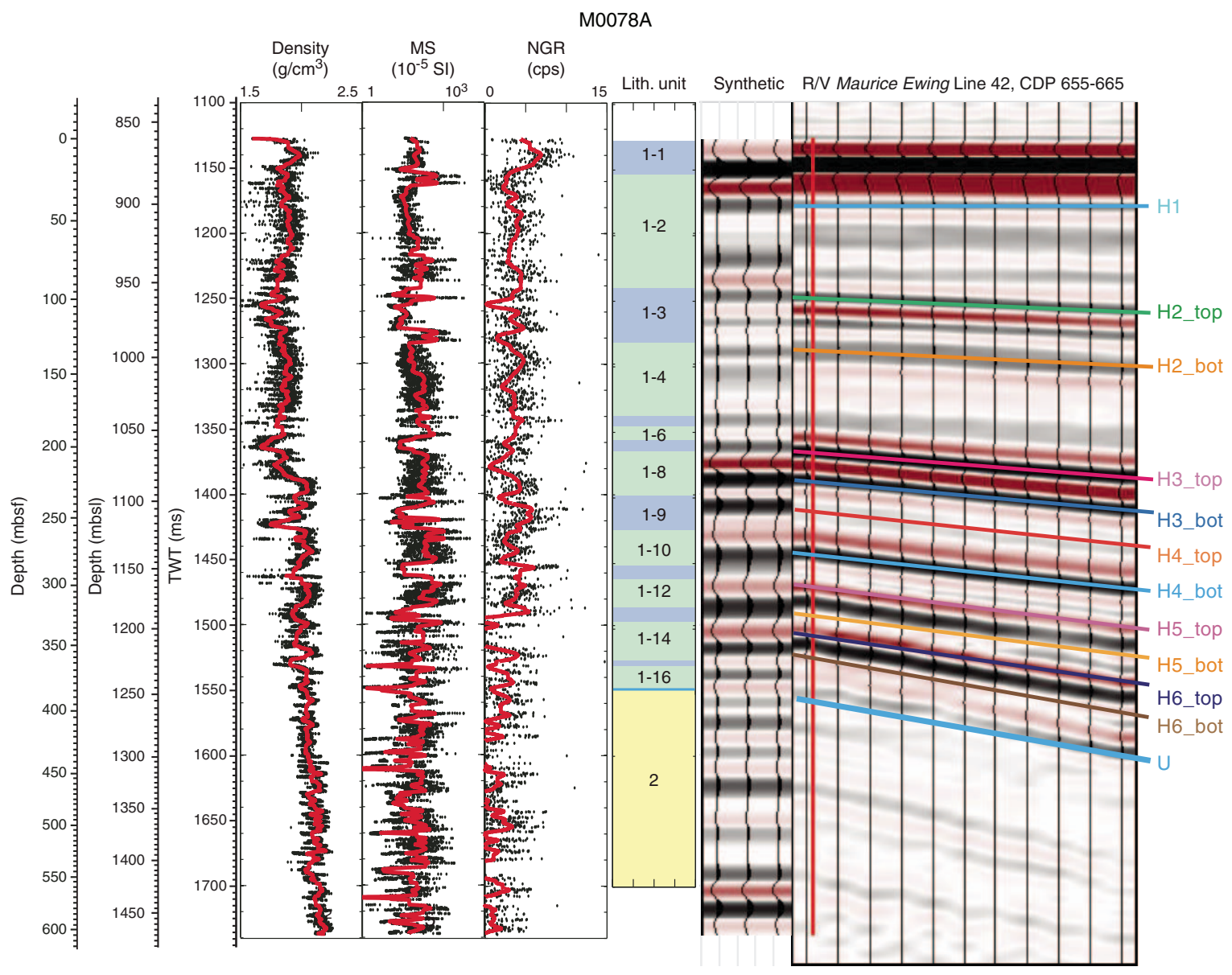

\section{References}

Anthonissen, D.E., and Ogg, J.G., 2012. Appendix 3-Cenozoic and Cretaceous biochronology of planktonic foraminifera and calcareous nannofossils. In Gradstein, F.M., Ogg, J.G., Schmitz, M.D., and Ogg, G.M., (Eds.), The Geologic Time Scale 2012: Amsterdam (Elsevier), 1083-1127. https://doi.org/10.1016/B978-0-444-59425-9.15003-6

Backman, J., Raffi, I., Rio, D., Fornaciari, E., and Pälike, H., 2012. Biozonation and biochronology of Miocene through Pleistocene calcareous nannofossils from low and middle latitudes. Newsletters on Stratigraphy, 45(3):221-244. https://doi.org/10.1127/0078-0421/2012/0022

Bell, R.E., McNeill, L.C., Bull, J.M., Henstock, T.J., Collier, R.E.L., and Leeder, M.R., 2009. Fault architecture, basin structure and evolution of the Gulf of Corinth Rift, central Greece. Basin Research, 21(6):824-855. https://doi.org/10.1111/j.1365-2117.2009.00401.x

Berner, R.A., 1980. Early Diagenesis: A Theoretical Approach: Princeton, NJ (Princeton University Press).

Capotondi, L., Girone, A., Lirer, F., Bergami, C., Verducci, M., Vallefuoco, M., Afferri, A., Ferraro, L., Pelosi, N., and De Lange, G.J., 2016. Central Mediterranean mid-Pleistocene paleoclimatic variability and its association with global climate. Palaeogeography, Palaeoclimatology, Palaeoecology, 442:72-83. https://doi.org/10.1016/j.palaeo.2015.11.009

Cvetkoska, A., Jovanovska, E., Francke, A., Tofilovska, S., Vogel, H., Levkov, Z., Donders, T.H., Wagner, B., and Wagner-Cremer, F., 2016. Ecosystem regimes and responses in a coupled ancient lake system from MIS $5 b$ to present: the diatom record of lakes Ohrid and Prespa. Biogeosciences, 13(10):3147-3162. https://doi.org/10.5194/bg-13-3147-2016

Cvetkoska, A., Reed, J.M., and Levkov, Z., 2012. Diatoms as indicators of environmental change in ancient Lake Ohrid during the last glacial-interglacial cycle (ca. 140 ka). In Witkowski, A. (Ed.), Diatom Monographs: Königstein, Germany (Koeltz Scientific Books).

Dimiza, M.D., Triantaphyllou, M.V., and Malinverno, E., 2014. New evidence for the ecology of Helicosphaera carteri in polluted coastal environments (Elefsis Bay, Saronikos Gulf, Greece). Journal of Nannoplankton Research, 34:37-43. http://ina.tmsoc.org/JNR/online/34/Dimiza et al 2014 JNR Crete.pdf

Dimiza, M.D., Triantaphyllou, M.V., Malinverno, E., Psarra, S., Karatsolis, B.T., Mara, P., Lagaria, A., and Gogou, A., 2016. The composition and distribution of living coccolithophores in the Aegean Sea (NE Mediterranean). Micropaleontology, 61(6):521-540. http://www.micropress.org/microaccess/micropaleontology/issue-321/article-1966

Duchemin, G., Fontanier, C., Jorissen, F.J., Barras, C., and Griveaud, C., 2007. Living small-sized $(63-150 \mu \mathrm{m})$ foraminifera from the mid-shelf to midslope environments in the Bay of Biscay. Journal of Foraminiferal Research, 37(1):12-32. https://doi.org/10.2113/gsjfr.37.1.12

Evitt, W.R., Gocht, H., and Netzel, H., 1985. Gonyaulax cysts from Lake Zürich sediments. Review of Palaeobotany and Palynology, 45(1-2):3546. https://doi.org/10.1016/0034-6667(85)90064-8

Ford, M., Rohais, S., Williams, E.A., Bourlange, S., Jousselin, D., Backert, N., and Malartre, F., 2013. Tectono-sedimentary evolution of the western 
Corinth Rift (central Greece). Basin Research, 25(1):3-25

https://doi.org/10.1111/j.1365-2117.2012.00550.x

Ford, M., Williams, E.A., Malartre, F., and Popescu, S.-M., 2007. Stratigraphic architecture, sedimentology and structure of the Vouraikos Gilbert-type fan delta, Gulf of Corinth, Greece. In Nichols, G., Paola, C., and Williams, E. (Eds.), Sedimentary Processes, Environments and Basins: A Tribute to Peter Friend. Jarvis, I. (Series Ed.). Special Publication of the International Association of Sedimentologists, 38:44-90. https://doi.org/10.1002/9781444304411.ch4

Froelich, P.N., Klinkhammer, G.P., Bender, M.L., Luedtke, N.A., Heath, G.R., Cullen, D., Dauphin, P., Hammond, D., Hartman, B., and Maynard, V., 1979. Early oxidation of organic matter in pelagic sediments of the eastern equatorial Atlantic: suboxic diagenesis. Geochimica et Cosmochimica Acta, 43(7):1075-1090. https://doi.org/10.1016/0016-7037(79)90095-4

Goineau, A., Fontanier, C., Jorissen, F.J., Lansard, B., Buscail, R., Mouret, A., Kerhervé, P., et al., 2011. Live (stained) benthic foraminifera from the Rhône prodelta (Gulf of Lion, NW Mediterranean): environmental controls on a river-dominated shelf. Journal of Sea Research, 65(1):58-75. https://doi.org/10.1016/j.seares.2010.07.007

Houk, V., Klee, R., and Tanaka, H., 2010. Atlas of Freshwater Centric Diatoms with a Brief Key and Descriptions: Part 3. Stephanodiscaceae A. Cyclotella, Tertiarius, Discostella: Praha, Czech Republic (Czech Phycological Society).

Hyndman, R.D., Erickson, A.J., and Von Herzen, R.P., 1974. Geothermal measurements on DSDP Leg 26. In Davies, T.A., Luyendyk, B.P., et al., Initial Reports of the Deep Sea Drilling Project, 26: Washington, DC (U.S. Government Printing Office), 451-463. https://doi.org/10.2973/dsdp.proc.26.113.1974

Kennedy, M. (Ed.), 2015. Practical Petrophysics (Volume 62): Developments in Petroleum Science. Cubitt, J. (Series Ed.): Amsterdam (Elsevier).

Kouli, K., Brinkhuis, H., and Dale, B., 2001. Spiniferites cruciformis: a fresh water dinoflagellate cyst? Review of Palaeobotany and Palynology, 113(4):273-286. https://doi.org/10.1016/S0034-6667(00)00064-6

Krammer, K., and Lange-Bertalot, H., 1991. Bacillariophyceae, Part 3. Centrales, Fragilariaceae, Eunotiaceae. In Ettl, H., Gerloff, J., Heynig, H., and Mollenhauer, D. (Eds.), Süßwaserflora von Mitteleuropa (Volume 2/3): Stuttgart, Germany (Gustav Fischer Verlag).

Lisiecki, L.E., and Raymo, M.E., 2005. A Pliocene-Pleistocene stack of 57 globally distributed benthic $\delta^{18} \mathrm{O}$ records. Paleoceanography, 20(1):PA1003. https://doi.org/10.1029/2004PA001071

Martini, E., 1971. Standard Tertiary and Quaternary calcareous nannoplankton zonation. In Farinacci, A. (Ed.), Proceedings of the Second Planktonic Conference, Roma 1970: Rome (Edizioni Tecnoscienza), 2:739-785.

McNeill, L.C., Shillington, D.J., Carter, G.D.O., Everest, J.D., Le Ber, E., Collier, R.E.Ll., Cvetkoska, A., De Gelder, G., Diz, P., Doan, M.-L., Ford, M., Gawthorpe, R.L., Geraga, M., Gillespie, J., Hemelsdaël, R., Herrero-Bervera, E., Ismaiel, M., Janikian, L., Kouli, K., Li, S., Machlus, M.L., Maffione, M., Mahoney, C., Michas, G., Miller, C., Nixon, C.W., Oflaz, S.A., Omale, A.P., Panagiotopoulos, K., Pechlivanidou, S., Phillips, M.P., Sauer, S., Seguin, J., Sergiou, S., and Zakharova, N.V., 2019a. Expedition 381 facies associations. In McNeill, L.C., Shillington, D.J., Carter, G.D.O., and the Expedition 381 Participants, Corinth Active Rift Development. Proceedings of the International Ocean Discovery Program, 381: College Station, TX (International Ocean Discovery Program). https://doi.org/10.14379/iodp.proc.381.103.2019

McNeill, L.C., Shillington, D.J., Carter, G.D.O., Everest, J.D., Le Ber, E., Collier, R.E.Ll., Cvetkoska, A., De Gelder, G., Diz, P., Doan, M.-L., Ford, M., Gawthorpe, R.L., Geraga, M., Gillespie, J., Hemelsdaël, R., Herrero-Bervera, E., Ismaiel, M., Janikian, L., Kouli, K., Li, S., Machlus, M.L., Maffione, M., Mahoney, C., Michas, G., Miller, C., Nixon, C.W., Oflaz, S.A., Omale, A.P., Panagiotopoulos, K., Pechlivanidou, S., Phillips, M.P., Sauer, S., Seguin, J., Sergiou, S., and Zakharova, N.V., 2019b. Expedition 381 methods. In McNeill, L.C., Shillington, D.J., Carter, G.D.O., and the Expedition 381 Participants, Corinth Active Rift Development. Proceedings of the International Ocean Discovery Program, 381: College Station, TX (Interna- tional Ocean Discovery Program).

https://doi.org/10.14379/iodp.proc.381.102.2019

McNeill, L.C., Shillington, D.J., Carter, G.D.O., Everest, J.D., Le Ber, E., Collier, R.E.Ll., Cvetkoska, A., De Gelder, G., Diz, P., Doan, M.-L., Ford, M., Gawthorpe, R.L., Geraga, M., Gillespie, J., Hemelsdaël, R., Herrero-Bervera, E., Ismaiel, M., Janikian, L., Kouli, K., Li, S., Machlus, M.L., Maffione, M., Mahoney, C., Michas, G., Miller, C., Nixon, C.W., Oflaz, S.A., Omale, A.P., Panagiotopoulos, K., Pechlivanidou, S., Phillips, M.P., Sauer, S., Seguin, J., Sergiou, S., and Zakharova, N.V., 2019c. Site M0079. In McNeill, L.C., Shillington, D.J., Carter, G.D.O., and the Expedition 381 Participants, Corinth Active Rift Development. Proceedings of the International Ocean Discovery Program, 381: College Station, TX (International Ocean Discovery Program). https://doi.org/10.14379/iodp.proc.381.105.2019

Mertens, K.N., Rengefors, K., Moestrup, Ø., and Ellegaard, M., 2012. A review of recent freshwater dinoflagellate cysts: taxonomy, phylogeny, ecology and palaeocology. Phycologia, 51(6):612-619.

https://doi.org/10.2216/11-89.1

Mudie, P.J., Marret, F., Mertens, K.N., Shumilovskikh, L., and Leroy, S.A.G., 2017. Atlas of modern dinoflagellate cyst distributions in the Black Sea Corridor: from Aegean to Aral Seas, including Marmara, Black, Azov and Caspian Seas. Marine Micropaleontology, 134. https://doi.org/10.1016/j.marmicro.2017.05.004

Mudie, P.J., Marret, F., Rochon, A., and Aksu, A.E., 2010. Non-pollen palynomorphs in the Black Sea corridor. Vegetation History and Archaeobotany, 19(5-6):531-544. https://doi.org/10.1007/s00334-010-0268-9

Nixon, C.W., McNeill, L.C., Bull, J.M., Bell, R.E., Gawthorpe, R.L., Henstock, T.J., Christodoulou, D., et al., 2016. Rapid spatiotemporal variations in rift structure during development of the Corinth Rift, central Greece. Tectonics, 35(5):1225-1248. https://doi.org/10.1002/2015TC004026

Perch-Nielsen, K., 1985. Cenozoic calcareous nannofossils. In Bolli, H.M., Saunders, J.B., and Perch-Nielsen, K. (Eds.), Plankton Stratigraphy: Cambridge, United Kingdom (Cambridge University Press), 427-554.

Pujol, C., and Vergnaud Grazzini, C., 1995. Distribution patterns of live planktic foraminifers as related to regional hydrography and productive systems of the Mediterranean Sea. Marine Micropaleontology, 25(2-3):187217. https://doi.org/10.1016/0377-8398(95)00002-I

Raffi, I., Backman, J., Fornaciari, E., Pälike, H., Rio, D., Lourens, L., and Hilgen, F., 2006. A review of calcareous nannofossil astrobiochronology encompassing the past 25 million years. Quaternary Science Reviews, 25(2324):3113-3137. https://doi.org/10.1016/j.quascirev.2006.07.007

Reed, J.M., Cvetkoska, A., Levkov, Z., Vogel, H., and Wagner, B., 2010. The last glacial-interglacial cycle in Lake Ohrid (Macedonia/Albania): testing diatom response to climate. Biogeosciences, 7(10):3083-3094. https://doi.org/10.5194/bg-7-3083-2010

Remane, J., 1985. Calpionellids. In Bolli, H., Saunders, J., and Perch-Nielsen, K. (Eds.), Plankton Stratigraphy. Cambridge, United Kingdom (Cambridge University Press), 555-572.

Rohling, E.J., and Gieskes, W.W.C., 1989. Late Quaternary changes in Mediterranean intermediate water density and formation rate. Paleoceanography and Paleoclimatology, 4(5):531. https://doi.org/10.1029/PA004i005p00531

Rohling, E.J., Jorissen, F.J., Vergnaud Grazzini, C., and Zachariasse, W.J., 1993. Northern Levantine and Adriatic Quaternary planktic foraminifera; reconstruction of paleoenvironmental gradients. Marine Micropaleontology, 21(1-3):191-218. https://doi.org/10.1016/0377-8398(93)90015-P

Sakellariou, D., Lykousis, V., Alexandri, S., Kaberi, H., Rousakis, G., Nomikou, P., Georgiou, P., and Ballas, D., 2007. Faulting, seismic-stratigraphic architecture and Late Quaternary evolution of the Gulf of Alkyonides BasinEast Gulf of Corinth, Central Greece. Basin Research, 19(2):273-295. https://doi.org/10.1111/j.1365-2117.2007.00322.x

Singer, B.S., 2014. A Quaternary geomagnetic instability time scale. Quaternary Geochronology, 21:29-52. https://doi.org/10.1016/j.quageo.2013.10.003

Skourtsos, E., and Kranis, H., 2009. Structure and evolution of the western Corinth Rift, through new field data from the northern Peloponnesus. In Ring, U., and Wernicke, B. (Eds.), Extending a Continent: Architecture, 
Rheology and Heat Budget. Geological Society Special Publication, 321(1):119-138. https://doi.org/10.1144/SP321.6

Taylor, B., Weiss, J.R., Goodliffe, A.M., Sachpazi, M., Laigle, M., and Hirn, A., 2011. The structures, stratigraphy and evolution of the Gulf of Corinth Rift, Greece. Geophysical Journal International, 185(3):1189-1219. https://doi.org/10.1111/j.1365-246X.2011.05014.x

Thierstein, H.R., Geitzenauer, K.R., Molfino, B., and Shackleton, N.J., 1977. Global synchroneity of late Quaternary coccolith datum levels validation by oxygen isotopes. Geology, 5(7):400-404.

https://doi.org/10.1130/0091-7613(1977)5<400:GSOLQC>2.0.CO;2
Van Dam, H., Mertens, A., and Sinkeldam, J., 1994. A coded checklist and ecological indicator values of freshwater diatoms from The Netherlands. Netherland Journal of Aquatic Ecology, 28(1):117-133. https://doi.org/10.1007/BF02334251

Wade, B.S., and Bown, P.R., 2006. Calcareous nannofossils in extreme environments: the Messinian salinity crisis, Polemi Basin, Cyprus. Palaeogeography, Palaeoclimatology, Palaeoecology, 233(3-4):271-286. https://doi.org/10.1016/j.palaeo.2005.10.007

Widess, M.B., 1973. How thin is a thin bed? Geophysics, 38(6):1176-1180. https://doi.org/10.1190/1.1440403 